\title{
RESUMOS DE DISSERTAÇÕES DE MESTRADO E TESES DE DOUTORADO APRESENTADAS NA FACULDADE DE MEDICINA DE RIBEIRÃO PRETO - USP DE JANEIRO A MARÇO DE 2008
}

\author{
BIOLOGIA CELULAR E MOLECULAR
}

\section{ESTUDO DA REGULAÇÃO TRANSCRICIONAL DE $r$ st NAS ETAPAS FINAIS DO DESENVOLVI- MENTO DO OLHO COMPOSTO DE Drosophila melanogaster}

\section{Shirlei Octacílio da Silva}

Orientador: Prof. Dr. Ricardo Guelerman Pinheiro Ramos

Tese de Doutorado apresentada em 28/01/2008

O desenvolvimento dos diferentes tipos celulares do olho composto de Drosophila melanogaster se dá através de uma combinação de sinais inibitórios e indutores enviados por células já especificadas para células adjacentes que são então recrutadas, tornando-se tipos celulares específicos. Ao final desta etapa, células em excesso sofrem morte celular programada.

O gene roughest (rst) é um locus pleiotrópico envolvido neste último e em vários outros processos do desenvolvimento de D. melanogaster. A proteína Rst é uma molécula da superfamília das imunoglobulinas, cuja integridade e precisa regulação temporal e espacial são importantes para que o gene desempenhe sua função. $O$ estudo da região reguladora deste gene se faz importante para entender seus precisos mecanismos de regulação.

Neste contexto, o alelo $r s t^{D}$, cuja mutação está associada a um rearranjo genômico localizado aproximadamente 18-19 kb a montante do putativo sítio de início da transcrição do locus é uma importante ferramenta para este entendimento. Além de ser o único alelo mutante da região reguladora de rst até o momento isolado, ele possui uma interessante característica: reversões para indivíduos com olhos praticamente selvagens e com olhos similares aos mutantes de perda-de-função. A caracterização prévia dos revertantes mostrou que eles têm comportamentos genético e molecular diferentes. Em termos fenotípicos, a expressão da proteína Rst na retina pupal em desenvolvimento em mutantes $r s t^{D}$, embora ocorra em padrões espacialmente comparáveis aos normais, apresenta um atraso em relação ao selvagem. Esta observação levou a um modelo da função de $r s t$ na retina pupal baseada em precisas alterações quantitativas dos seus níveis de mRNA e proteína ao longo do desenvolvimento do olho composto, que seriam importantes para sua correta função.

Com o conhecimento acumulado até o momento sobre este importante alelo, este trabalho teve o intuito de caracterizar a alteração molecular deste mutante, entender como esta alteração afeta a regulação da expressão gênica e, conseqüentemente, quais os mecanismos de regulação deste gene, além de compreender a instabilidade molecular desta mutação.

Assim, vários fragmentos dentro da região onde foi previamente mapeado o rearranjo foram isolados através de PCR e seqüenciados. O conhecimento destas seqüências não foi suficiente para se caracterizar o rearranjo; porém, estes dados, somados aos resultados do "Southern blot" genômico anterior, levantam a hipótese de que possa haver uma duplicação da mesma região selvagem. Este fato também foi observado para todos os estoques de revertantes, sendo que alguns possuem apenas uma deleção extra de 12 pares de bases, diferente do selvagem e de $r s t^{D}$. Partindo-se desta nova hipótese, outras abordagens deverão ser utilizadas no sentido de se estabelecer a natureza do rearranjo e seus mecanismos de instabilidade.

Finalmente, com o objetivo de confirmar o modelo de produção, redistribuição e reciclagem de Rst, experimentos preliminares de PCR quantitativo em tempo real foram realizados, com os quais se pôde confirmar a variação temporal dos níveis de mRNA rst no selvagem e estabelecer diferenças na sua regulação em relação ao mutante. Estes resultados, em conjunto com os dados previamente obtidos, corroboram a hipótese de que a interferência molecular da regulação da transcrição de $r s t$ pode levar à localização errada da proteína, o que irá interferir na sua função e, conseqüentemente, produzir defeitos no olho composto adulto.

\section{DISSECÇÃO FUNCIONAL in vivo DA MOLÉCULA DE ADESÃO CELULAR ROUGHEST DURAN- TE O DESENVOLVIMENTO EMBRIONÁRIO DE Drosophila melanogaster}

Lívia Maria Rosatto Moda

Orientador: Prof. Dr. Ricardo Guelerman Pinheiro Ramos

Tese de Doutorado apresentada em 31/01/2008
Roughest (Rst) é uma molécula com características de adesão e sinalização celular filogeneticamente conservada, pertencente à superfamília das imunoglobulinas, que 
também inclui os produtos dos genes kin of irre, (kirre), hibris (hbs) e stick and stones (sns) de Drosophila, as proteínas SYG-1 e SYG-2 de C. elegans; Nephrin, Neph1, Neph2 e Neph3 de Mus musculus e Homo sapiens, assim como homólogos menos caracterizados em D. virilis e Anopheles sp. Adicionalmente, rst apresenta múltiplas funções durante o desenvolvimento de Drosophila, entre eles: direcionamento axonal do lobo óptico, morte celular programada e diferenciação das células pigmentares do olho composto, padronização dos órgãos sensoriais da antena e histólise das glândulas salivares. Seu mRNA é expresso em um padrão complexo e dinâmico, temporal e espacialmente em larvas de terceiro instar, pupas e em embriões, sendo observado inicialmente no estágio 4 da embriogênese e continuando pelo menos até o estágio 14 (10:30 a 11:30 horas após a fertilização, a $25^{\circ} \mathrm{C}$ ).

Há alguns anos, o estudo da função de rst durante a embriogênese vem sendo realizado em nosso laboratório. Experimentos prévios haviam demonstrado que embriões transgênicos expressando de forma generalizada a construção pCa18D3.1, contendo uma versão truncada do cDNA de rst codificando somente o domínio extracelular da proteína (EcdRst), apresentavam uma diminuição significativa de sua viabilidade. $\mathrm{O}$ estudo mais detalhado deste fenótipo revelou dois períodos de letalidade independentes, um mais tardio, quando os embriões são submetidos ao choque térmico entre 8-10 horas após a fertilização e outro mais inicial entre 0-2 horas. Durante o período de letalidade inicial, a superexpressão de EcdRst leva a um desacoplamento entre os processos de divisão nuclear e de formação dos sulcos de clivagem, que definem a transição do blastoderma sincicial para o celular. Adicionalmente, alterações na organização do sistema nervoso foram esporadicamente observadas, sugerindo uma possível complexidade fenotípica decorrente da superexpressão de EcdRst nesta fase.

Neste trabalho foi realizado um estudo mais aprofundado do período inicial de letalidade visando caracterizar um possível envolvimento de rst na formação do sistema nervoso central embrionário. Nossos resultados revelaram a existência de 3 sub-períodos fenotipicamente distintos quando o choque térmico era aplicado em intervalos de 30 minutos durante o início da embriogênese, sendo que ativação do transgene nos superíodos mais tardios levava a um aumento significativo no número de embriões com defeitos no SNC. A análise morfológica deste fenótipo com um anticorpo específico de populações neurais mostrou que o principal defeito presente era separação longitudinal das duas metades da corda ventral, ao nível da linha media, principalmente na região correspondente aos dois ou três parasegmentos abdominais mais proximais. Apesar da superexpressão de EcdRst ocorrer entre os estágios 3 e 6 , nenhuma anormalidade no desenvolvimento destes embriões foi observada até o estágio 12, e nos estágios 14 e 15 embriões com defeitos na estrutura das comissuras e dos conectivos longitudinais do SNC começam a ser observados. Estes resultados sugerem, pela primeira vez, de forma conclusiva um papel para Rst no desenvolvimento do CNS embrionário.

Tendo em vista que esta proteína truncada não possui uma região transmembrana, podendo assim ser secretada para o espaço extracelular, é possível que este fenótipo seja devido à associação desta proteína truncada com alguma outra proteína desempenhando um papel no desenvolvimento do SNC. Para testar esta possibilidade foram investigadas possíveis interações fenotípicas entre Rst e outra proteína Ig-CAM em Drosophila, Hibris (Hbs). Além de recentes estudos demonstrarem diretamente ligações heterofílicas entre Rst e Hbs na retina pupal em desenvolvimento, ambos são expressos nas células da linha média aproximadamente durante o mesmo estágio, fato que nos leva a acreditar que Hbs seja um candidato para esta associação. De fato, um aumento significativo na freqüência e severidade dos fenótipos de defeitos no sistema nervoso embrionário foram observados em indivíduos transgênicos onde os níveis endógenos da proteína Hibris foram geneticamente diminuídos. Estes dados são compatíveis com a hipótese do domínio extracelular de Rst sozinho ser suficiente para antagonizar, a função de Hibris na estabilização da linha média do sistema nervoso central, provavelmente competindo com a proteína Rst endógena selvagem, e sugerem fortemente uma interação direta entre Rst e Hbs durante a formação da corda ventral.

Tomados em conjunto, os resultados aqui apresentados contribuem para uma melhor compreensão das funções do gene rst durante o desenvolvimento embrionário de Drosophila melanogaster.

\section{CARACTERIZAÇÃO DA PROTEÍNA KIAA0090 SUGERE SUA ASSOCIAÇÃO COM MITOCÔN- DRIA E RETÍCULO ENDOPLASMÁTICO E SEU ENVOLVIMENTO EM APOPTOSE}

\section{Milene Mantovani Lopes}

Orientadora: Profa. Dra. Enilza Maria Espreafico

Dissertação de Mestrado apresentada em 01/02/ 2008

Em um estudo prévio, nós observamos um aumento dos níveis de mRNA da KIAA0090, um gene conservado evolutivamente, sem função conhecida, em linhagens celulares metastáticas, comparadas a linhagens celulares de estágios tumorais iniciais. Para analisar a localização e função da proteína KIAA0090 em tecidos e células, nós iniciamos a sua caracterização. A proteína de fusão EGFP-KIAA agrega rapidamente em uma região perinuclear, promovendo uma 
dramática co-agregação mitocondrial. Colocalização com marcação de ubiquitina, vimentina e proteassomo sugere uma similaridade entre esses agregados e agressomos. A outra proteína de fusão KIAA-EGFP está restrita ao retículo endoplasmático (RE) e, quando o seu nível de expressão aumenta, induz uma expansão evidente do RE, associada ao aumento dos níveis de uma chaperona de RE, a calreticulina. Além disso, nós observamos um padrão de distribuição diferente para a proteína KIAA0090 superexpressa sem etiqueta de fusão. Tal fato sugere que as fusões com a EGFP estejam interferindo no correto endereçamento das proteínas recombinantes. Ambas as proteínas de fusão KIAA0090/EGFP induzem a morte celular, em células de melanoma. Esse processo não envolve a liberação de citocromo c, mas requer ativação de caspase, já que um inibidor de caspase-3 inibiu parcialmente a morte celular. A KIAA0090 endógena parece estar associada, predominan- temente, com mitocôndrias, em células de melanoma e em células linfoblásticas e proleucêmicas, havendo marcações variáveis, com níveis menos pronunciados, no citoplasma e no núcleo. Uma análise em tecidos de ratos mostrou marcações da KIAA0090 em músculo liso vascular e visceral, músculo esquelético e linfonodos, dentre outros tecidos. Análises por Western blotting revelaram múltiplos polipeptídeos de massas moleculares que variam de 40 a 130 kDa. Dados de ESTs, disponíveis nos bancos públicos, e nossos resultados de diferentes localizações entre a KIAA0090 endógena e as recombinates suportam a existência de múltiplas isoformas da proteína, que podem ser endereçadas a diferentes compartimentos subcelulares. Esses resultados mostrados aqui, junto com várias outras análises de estudos em larga escala, sugerem que a função da KIAA0090 pode estar envolvida em vias de apoptose/estresse e pode exercer um papel na progressão tumoral.

\section{ESTUDOS PROTEÔMICOS DE LINFÓCITOS B DE PACIENTES PORTADORES DE LEUCEMIA LINFOCÍTICA CRÔNICA}

\author{
Vanessa Cristina de Oliveira Souza \\ Orientador: Prof. Dr. José César Rosa \\ Dissertação de Mestrado apresentada em 26/02/2008
}

As doenças linfoproliferativas crônicas (DLC) compreendem um grupo bastante heterogêneo de doenças caracterizadas por um acúmulo de células linfóides maduras. A leucemia linfocítica crônica (LLC) é a mais comum das doenças linfoproliferativas crônicas. A LLC pode ser classificada com base na classificação clínica de Binet, sendo as três variantes conhecidas como A (baixo risco), B (risco intermediário) e $\mathrm{C}$ (alto risco), respectivamente. No presente trabalho avaliamos o perfil de expressão de proteínas, em células mononucleares de 14 pacientes portadores de LLC e 3 indivíduos saudáveis, utilizando a abordagem proteômica. Embora o padrão dos mapas 2D de células saudáveis e neoplásicas tenha sido muito semelhante, nós detectamos nos géis IPG 3-10NL um grupo de 26 spots e nos géis IPG 4-7L, obtivemos 22 spots diferencialmente expressos ( \pm 2 vezes), quando comparados com seus respectivos controles e correlacionamos algumas destas proteínas com a classificação de Binet. Os spots selecionados foram caracterizados por espectrometria de massas (MALDI-TOF ou ESI-3Q) e identificados através da abordagem de "Peptide Mass Fingerprinting" e por seqüenciamento de aminoácidos dos peptídeos obtidos por ESI-CID-MS/MS. Nós identificamos 17 spots, correspondendo a 10 proteínas diferentes, dentre elas Heterogeneous nuclear ribonucleoprotein A2/B1, 14-3-3 Protein zeta/delta, Protein kinase C inhibitor protein 1 e S100-A8.

\section{ABORDAGEM PROTEÔMICA NA PROGRESSÃO TUMORAL DE GLIOMAS}

\section{Marcela Gimenez \\ Orientador: Prof. Dr. José César Rosa \\ Dissertação de Mestrado apresentada em 29/02/2008}

As células gliais podem mutar para formar células tumorais gliais ou gliomas. Como tumorigênese em outros tecidos, o desenvolvimento de um tumor cerebral depende de mutações que mudam proto-oncogenes para oncogenes ou inativam genes supressores de tumores. Várias alterações genéticas, tais como o envolvimento de caminhos metabólicos e de controle do ciclo celular, têm sido detectadas e catalogadas para servirem de alvos moleculares para o desenvolvimento de novas terapias. Proteômica é um dos campos mais complexos, e novas tecnologias e estratégias aparecem a cada ano. $\mathrm{O}$ desenvolvimento de câncer é causado por acúmulo de mutações no DNA promovendo mudanças em genes, mas analises genômicas não reportam com exatidão a situação ao nível das proteínas, e câncer está sendo altamente reconhecido como uma doença das proteínas, de tal forma que, a proteômica representa um atalho entre mudanças no genoma e desenvolvimento de 
câncer. A proteômica tenta buscar informações para elucidar a função de genes através de uma análise sistemática e global de proteínas diferencialmente expressas.

Nós desenvolvemos um estudo proteômico baseado em eletroforese bidimensional (2DE) e espectrometria de massas (MALDI-TOF e ESI-MS/MS) para comparar e identificar a expressão diferencial de proteínas na progressão tumoral de gliomas astrocíticos, de acordo com o aumento dos graus de malignidade (graus II, III e IV). As proteínas nucleofosmina, alfa-cristalina cadeia B e anexinas A1 e A5, identificadas como aumentadas em glioma de altograu, merecem destaque pelo possível envolvimento em diversos processos tais como proliferação e crescimento de tumores. O estudo da expressão diferencial de proteínas deve refletir o estado fisiopatológico das células cancerosas, tornando as proteínas candidatas a biomarcadores para diagnóstico, prognóstico e/ou alvo no desenvolvimento de estratégias terapêuticas e novos fármacos.

\section{BIOQUÍMICA}

\section{GLICERONEOGÊNESE E FONTES DE GLICEROL-3-FOSFATO PARA A SÍNTESE DE GLICERÍ- DEO-CLICEROL NO FÍGADO DE RATOS EM DIVERSAS SUTUAÇÕES EXPERIMENTAIS}

\section{Maria Emilia Soares Martins dos Santos}

Orientador: Prof. Dr. Renato Hélios Migliorini

Tese de Doutorado apresentada em 29/01/2008

O presente trabalho teve o propósito de investigar em várias situações experimentais as vias de geração de glicerol-3-fosfato em fatias de figado. Foi verificado também o efeito da desnervação hepática prévia sobre estes processos. A geração de glicerol-3-fosfato pelas três vias foi avaliada: através da via glicolítica, estimada pelo fluxo glicolítico e pela incorporação de U- ${ }^{14} \mathrm{C}$-glicose em glicerídeo-glicerol; pela medida da atividade da gliceroquinase e da incorporação de U- ${ }^{14} \mathrm{C}$-glicerol em glicerídeo-glicerol e pela medida da atividade da fosfoenolpiruvato carboxiquinase (PEPCK) e da incorporação de $2{ }^{14} \mathrm{C}$-piruvato em glicerídeo-glicerol. Os experimentos foram realizados no figado de ratos nas seguintes situações: normalmente alimentados, jejuados (48 horas), diabéticos (72 horas), tratados com uma dieta hiperproteica (dieta HP) e tratados com uma dieta hiperlipídica e hipercalórica do tipo cafeteria. O conteúdo de noradrenalina do tecido hepático, um índice da atividade simpática, estava aumentado tanto no jejum, diabetes e ratos alimentados com uma dieta cafeteria e diminuído nos ratos alimentados com a dieta HP. A desnervação hepática causou uma marcante diminuição no conteúdo de noradrenalina em todas as situações estudadas. Os animais normalmente alimentados e desnervados apresentaram uma diminuição na atividade da gliceroquinase e da incorporação de U- ${ }^{14} \mathrm{C}$-glicerol em glicerídeo-glicerol. A incorporação deste mesmo substrato em glicose do meio não foi alterada pela desnervação. A atividade da PEPCK, a incorporação de $2-{ }^{14} \mathrm{C}$-piruvato em glicerídeo-glicerol e em glicose do meio, a incorporação de $\mathrm{U}^{14} \mathrm{C}$-glicose em glice- rídeo-glicerol e o fluxo glicolítico não foram alterados pela desnervação hepática. O jejum e o diabetes não alteraram a atividade da gliceroquinase e nem a incorporação de $\mathrm{U}-{ }^{14} \mathrm{C}$ -glicerol em glicerídeo-glicerol. Entretanto, a incorporação deste substrato em glicose do meio mostrava-se aumentada nas duas situações. A desnervação hepática não foi capaz de alterar nenhum destes parâmetros. A PEPCK assim como a incorporação de $2-{ }^{14} \mathrm{C}$ - piruvato em glicerídeoglicerol e em glicose do meio encontravam-se aumentadas nos animais jejuados e diabéticos sendo que esses achados não sofreram modificações pela desnervação. A incorporação de $\mathrm{U}_{-}{ }^{14} \mathrm{C}$-glicose em glicerídeo-glicerol e o fluxo glicolítico encontravam-se diminuídos nessas duas situações e a desnervação não afetou estes parâmetros. Os animais tratados com a dieta HP apresentaram uma diminuição da atividade da gliceroquinase bem como uma diminuição da incorporação de $\mathrm{U}^{1}{ }^{14} \mathrm{C}$-glicerol em glicerídeo- glicerol sendo que a desnervação reduziu ainda mais a atividade da enzima. A incorporação deste substrato em glicose do meio encontrava-se aumentada e não se modificou com a desnervação. A atividade da PEPCK assim como a incorporação de $2-{ }^{14} \mathrm{C}$-piruvato em, glicerídeo-glicerol e em glicose do meio encontravam-se aumentadas e também não sofreram alterações com a desnervação. A incorporação de U${ }^{14} \mathrm{C}$-glicose em glicerídeo-glicerol e o fluxo glicolítico encontravam-se reduzidos nos animais tratados com a dieta HP sendo que a desnervação não afetou estes parâmetros. Os animais adaptados à dieta $\mathrm{N}$ e desnervados apresentaram uma diminuição na atividade da gliceroquinase e da incorporação de $\mathrm{U}-{ }^{14} \mathrm{C}$ - glicerol em glicerídeo-glicerol. A incorporação deste mesmo substrato em glicose do meio não foi alterada pela desnervação. A atividade da PEPCK, a incorporação de $2-{ }^{14} \mathrm{C}$-piruvato em glicerídeo-glicerol e em 
glicose, o fluxo glicolítico e a incorporação de U- ${ }^{14} \mathrm{C}$-glicose em glicerídeo-glicerol também não foram alterados pela desnervação hepática. Os animais tratados com a dieta cafetecia apresentaram um aumento na atividade da gliceroquinase que foi reduzida pela desnervação. A incorporação de $\mathrm{U}-{ }^{14} \mathrm{C}$-glicerol em glicerídeo-glicerol e em glicose do meio encontravam-se diminuídas sendo que a desnervação só foi capaz de reduzir a incorporação de glicerol em glicerídeo-glicerol. A atividade da PEPCK e a incorporação de $2-{ }^{14} \mathrm{C}$-piruvato em glicerídeo-glicerol e em glicose encontravam- se diminuídas e a desnervação não foi capaz de alterar estes parâmetros. O fluxo glicolítico bem com a incorporação de $\mathrm{U}_{-}{ }^{14} \mathrm{C}$-glicose em glicerideoglicerol encontravam-se aumentados e a desnervação não alterou estes achados. Nossos resultados sugerem que existe um efeito compensatório na geração de glicerol-3 fosfato pelo figado entre a via gliceroneogênica e a via glicolítica em todas as situações estudadas. Quando uma está aumentada a outra está inibida e vice-versa. Os níveis de insulina plasmática parecem ser os maiores responsáveis por este padrão de resposta. A regulação destas vias parece não estar sob o controle do sistema nervoso simpático. Em contra partida, a fosforilação direta do glicerol pela gliceroquinase parece estar sob o controle do sistema nervoso simpático já que a desnervação hepática foi capaz de reduzir tanto a atividade enzimática quanto a incorporação de glicerol em glicerideo-glicerol. Porém, esta regulação parece tornar-se mais evidente quando há um somatório de fatores como a presença da insulina e a alteração do fluxo simpático para o tecido, principalmente nas situações de ratos adaptados a uma dieta $\mathrm{HP}$ e ratos adaptados à dieta cafeteria.

\section{SILENCIAMENTO DOS GENES DA PKR E DO RECEPTOR DE QUIMIOCINA CXCR4 ATRAVÉS DE RNA DE INTERFERÊNCIA : EFEITOS SOBRE O CRESCIMENTO TUMORAL E O POTENCI- AL METASTÁTICO DAS CÉLULAS DE MELANOMA 816-F10}

\section{Nayara Delgado André \\ Orientador: Prof. Dr. Fernando Luiz De Lucca \\ Tese de Doutorado apresentada em 11/02/2008}

O presente estudo utilizou a tecnologia do RNA de interferência (RNAi) no modelo de melanoma murino com o objetivo de investigar o papel da proteína quinase dependente de RNA (PKR) e do receptor de quimiocina CXCR4 sobre o crescimento tumoral e o potencial metastático das células de melanoma B16-F10. O RNAi tem sido utilizado, nos últimos anos, como uma importante ferramenta na elucidação da função gênica em células de mamíferos. $\mathrm{O}$ RNAi induz o silenciamento gênico pós-transcricional, o qual é seqüência específico e mediado por um RNA de dupla fita (dsRNA) de seqüência homóloga à do RNAm alvo. As moléculas longas de dsRNA são processadas pela enzima Dicer, resultando na produção de siRNAs (small interfering RNAs). O silenciamento gênico em células de mamíferos tem sido obtido através da transfecção com siRNAs sintéticos ou com auxílio de vetores de expressão, cujos promotores são reconhecidos pela RNA polimerase III, resultando na síntese de short hairpin RNAs (shRNAs), os quais produzem siRNAs pela ação da Dicer. Estudos sobre a participação da PKR no controle da proliferação celular sugerem que a PKR atua como supressor de tumor. Entretanto, os resultados obtidos com animais transgênicos não confirmaram esta hipótese, verificando-se ainda que ocorre um aumento da expressão e atividade da PKR em vários tipos de tumores humanos. Portanto, a participação da PKR no controle da proliferação celular é ainda um problema aberto à investigação. As células de melanoma expressam um eleva- do nível do RNAm do receptor de quimiocina CXCR4 em relação aos melanócitos normais e o seu ligante SDF-1a também está elevado nos pulmões, o que explicaria a freqüência alta de metástase pulmonar. Por outro lado, o papel desempenhado pelo receptor CXCR4 no melanoma murino não foi ainda investigado. Neste trabalho, o silenciamento dos genes da PKR e do receptor CXCR4 foi realizado através da transfecção das células de melanoma B16-F10 com o plasmídeo psiSTRIKE (Promega), o qual expressa os shRNAs anti-PKR ou anti-CXCR4. Na primeira etapa deste trabalho foi possível demonstrar in vitro, através das técnicas de RT -PCR semi-quantitativo e Western Blot, uma redução significativa da expressão do RNAm da PKR (98\%) e do CXCR4 (81\%) após 48 horas da transfecção das células de melanoma B16F10. A sequiência do shRNA controle não está presente no genoma de camundongo. Com relação aos efeitos in vivo, verificou-se uma redução significativa do peso tumoral nos camundongos que receberam uma injeção subcutânea de células B16-F10 transfectadas com os plasmídeos anti-PKR (86\%) ou anti-CXCR4 (66\%). A administração intratumoral destes plasmídeos foi também eficaz em reduzir significativamente o desenvolvimento tumoral tanto no caso do plasmídeo anti-PKR (82\%) como com o plasmídeo antiCXCR4 (70\%). Com o objetivo de se estudar a participação da PKR e do receptor CXCR4 no desenvolvimento de metástase experimental, as células de melanoma B16-F10 transfectadas com plasmídeos anti- PKR ou anti-CXCR4 foram inoculadas via endovenosa e a colonização pulmonar avaliada no '21GRAUS' dia. Os resultados mostraram uma redução dramática do número de nódulos pulmonares metastáticos quando as células tumorais injetadas foram 
previamente transfectadas com o plasmídeo anti-PKR (95\%) ou plasmídeo anti- CXCR4 (94\%). Os nossos dados sugerem ainda que os efeitos da PKR no melanoma murino são mediados pelo fator de transcrição NF- 'capa'B. Em resumo, o presente estudo revelou que a redução transitória da expressão da PKR e do receptor CXCR4 foi capaz de inibir tanto o crescimento do melanoma B 16 como também a formação de nódulos pulmonares metastáticos. Portanto, os nossos resultados não suportam o conceito de que a PKR atua como supressor de tumor e sugerem que a PKR desempenha um papel crítico na fase inicial do desenvolvimento tumoral e na formação de metátases. Assim, os genes da PKR e do receptor CXCR4 seriam alvos potenciais para o tratamento de câncer com a tecnologia do RNAi, especialmente em tumores que apresentam um aumento da expressão da PKR e do receptor CXCR4 e um elevado potencial metastático como observado nos casos de melanoma humano e de câncer de mama.

\section{ANÁLISE DE FATORES CELULARES E MOLECULARES ENVOLVIDOS NA TROMBOCITOPENIA DA INFECÇÃO PELO VÍRUS DENGUE}

\section{Camila Maciel de Sousa}

Orientador: Prof. Dr. Luis Hildebrando Pereira da Silva

Tese de Doutorado apresentada em 19/02/2008

As plaquetas na circulação normalmente não aderem ao endotélio vascular. Algumas vezes, em resposta a distúrbios na hemostasia por injúria vascular ou a fatores imunológicos, as plaquetas ativadas aderem às células endoteliais estimuladas. O aumento da aderência das plaquetas ativadas as células do endotélio vascular estimuladas pode contribuir para a trombocitopenia observada em muitas patologias inclusive na infecção pelo vírus dengue. Em nosso estudo, verificamos um aumento na ade- rência das plaquetas em HUVEC e CHO, transfectadas com genes dos receptores CD36, ICAM-1 ou VCAM-1. quando estas foram infectadas pelo vírus dengue soro tipo 3 ou estimuladas com sobrenadante de macrófagos infectados pelo mesmo vírus. Além da aderência plaquetária foi avaliado, por citometria de fluxo em $\mathrm{CHO}$, a presença dos receptores CD36, ICAM- e VCAM-1. Nossos resultados sugerem que em uma infecção pelo vírus dengue a resposta imunológica do hospedeiro causa distúrbios na hemostasia que ocasionam um sequiestro das plaquetas via moléculas de adesão do endotélio vascular para o espaço pericapilar, contribuindo assim com a trombocitopenia e em conseqüência disto as hemorragias ocasionadas nesta virose.

\section{REGULAÇÃO DA EXPRESSÃO GÊNICA PELO pH NO FUNGO FILAMENTOSO Aspergillus nidulans: FUNCIONALIDADE DO GENE paLA}

\section{Emiliana Mandarano da Silva}

Orientador: Prof. Dr. Antonio Rossi Filho

Tese de Doutorado apresentada em 25/02/2008

A via transdutora de sinal mediada pelo fator de transcrição PacC atua em muitos eventos metabólicos envolvidos na resposta adaptativa ao $\mathrm{pH}$ alcalino em Aspergillus nidulans. O gene pacC codifica um fator de transcrição zincfinger, e os seis genes pal ( $A, B, C, F, H$ e $I)$ são membros putativos de uma cascata sinalizadora que promovem a ativação proteolítica de PacC em ambiente alcalino. A proteína PalA interage com os motivos YPXL/I em PacC, o que é necessário para a ação de PalB, uma protease da família das calpaínas. Assim, qualquer que seja o pH de cultivo, a mutação palAl deveria mimetizar o fenótipo selvagem. Este modelo implica que mutações acarretando perda de função em qualquer dos genes pal levariam a mimetização do fenótipo ácido (selvagem) independentemente do $\mathrm{pH}$ ambiente, o que não foi observado na linhagem mutante biAl palAl.
Com a finalidade de identificar genes envolvidos na resposta adaptativa ao $\mathrm{pH}$ ambiente e avançar no entendimento da funcionalidade do gene palA em pH ácido, a hibridação subtrativa por supressão foi realizada a partir dos mRNAs isolados das linhagens biAl (requer biotina; Fungal Genetic Stock Center, linhagem \#A26) e biA1 palA1 (mimetiza crescimento de $\mathrm{pH}$ ácido; Fungal Genetic Stock Center, linhagem \#A243) de A. nidulans cultivadas em condições de fosfato limitante, $\mathrm{pH} 5,0$. Este estudo revelou genes com expressão elevada na linhagem mutante biAl palAl envolvidos em fidelidade mitótica, resposta ao estresse, mecanismos de transdução de sinal, desenvolvimento, estabilidade genômica, secreção enzimática, regulação pelo fosfato, etc. A expressão diferencial de oito desses genes, confirmada por Northern blot, indica que o gene palA tem função metabólica específica em pH ácido em A.nidulans.

A análise estrutural das frações enzimáticas secretadas pela linhagem mutante biAl palAl em ambiente ácido mostrou que estas frações apresentaram níveis reduzidos 
de glicosilação e maior sensibilidade à temperatura em relação à linhagem selvagem biA1. O seqüenciamento das proteínas secretadas pela linhagem mutante biAl palAl em pH 5,0 revelou uma fosfatase ácida Pi-repressível e uma fosfolipase $\mathrm{C}$ codificadas pelos genes $\mathrm{pacA}$ e $\mathrm{plcB}$, respectivamente. Além disso, o seqüenciamento das proteínas secretadas pela linhagem selvagem revelou isoformas da fosfatase ácida Pi-repressível codificada pelo gene pacA. Estes resul- tados indicam que o gene palA está envolvido em modificações pós-traducionais dessas enzimas e que, possivelmente, a proteína PalA é funcional em condições ácidas, promovendo a proteólise ou outro tipo de processamento molecular envolvido na ativação de PacC. Dessa forma, em função dos resultados apresentados neste trabalho e daqueles fornecidos pela literatura, foram propostas modificações para o modelo hierárquico previamente estabelecido.

\section{INFLUÊNCIA DE MEDIADORES QUÍMICOS E FÍSICOS NA MODELAGEM ESTRUTURAL E FUN- CIONAL DO PROTEASSOMA DE SCHISTOSOMA MANSONI}

\section{Érika Bueno de Carvalho Moreira}

Orientador: Prof. Dr. Vanderlei Rodrigues

Dissertação de Mestrado apresentada em 26/02/2008

A modelagem estrutural e funcional do sistema proteolítico ubiquitina-proteassoma apresenta diversas vias de alterações em vários sistemas biológicos, as quais são influenciadas especialmente pelas condições biológicas, químicas e fisicas do ambiente. No presente estudo, foi analisada a expressão gênica de SmPOMP, nos diferentes estágios de desenvolvimento de Schistosoma mansoni, já que esta proteína é demonstrada como uma clássica participante da modelagem estrutural do proteassoma, assim como o efeito químico provocado pelo inibidor da atividade peptidásica do proteassoma (MG-132) e do IBMX conhecido inibidor de vias de sinalização mediadas pelo AMPc. Avaliamos também os efeitos desencadeados por condições de estresse ténnico, na modulação do proteassoma. Nossos resultados demonstraram uma expressão diferenci- al de SmPOMP durante fases do ciclo biológico de S. mansoni, sugerindo que a montagem de novos proteassomas seja requeri da de acordo com necessidades celulares específicas. Além disso, foi observado um aumento na expressão de SmPOMP sob efeito do inibidor do proteassoma MG132, como urna resposta compensatória à inibição. Sob o efeito de IBMX foi observado em cultivo in vitro de vennes adultos, um aumento na motilidade e a inibição da ovoposição e, com relação à modulação, foi demonstrada uma diminuição da atividade do proteassoma e concomitante aumento na expressão de SmPOMP. Frente ao estresse térmico a expressão de SmPOMP se mostrou de forma diferencial.A atividade exógena do proteassoma parece aumentada quando comparada ao controle negativo tratado com MG-132. A partir desses resultados passamos a identificar e caracterizar moléculas mecanismos possivelmente envolvidos na modulação do proteassoma de S. mansoni, bem como uma adaptação do próprio parasito frente às condições físicas e químicas impostas peloambiente externo.

\section{PRODUÇÃO, PURIFICAÇÃO E CARACTERIZAÇÃO DO COMPLEXO PECTINOLÍTICO DO FUN- GO Aspergillus niveus}

\begin{abstract}
Alexandre Maller
Orientadora: Prof. Dra. Maria de Lourdes T. de M. Polizeli Dissertação de Mestrado apresentada em 28/02/2008

Pectina é o maior componente da parede celular de plantas. Esses polissacarídeos podem ser degradados por enzimas pécticas, nomeadas, pectinases. Podem ser classificadas, baseado em seu mecanismo de degradação, em enzimas desesterificantes e despolimerizantes. Pectinases são importantes enzimas industriais, utilizadas principalmente para aumentar a eficiência de filtração e clarificação de sucos de frutos, na maceração, liquefação e extração de tecidos vegetais, mas podem ser responsáveis pela pato-
\end{abstract}

gênese em plantas. São amplamente produzidas por vários fungos filamentosos, como Aspergillus sp. O objetivo deste trabalho foi estudar a produção do sistema pectinolítico do Aspergillus niveus, purificação e caracterização bioquímica das poligalacturonases.

Depois do "screening" entre alguns fungos filamentosos, o A. niveus foi o microrganismo selecionado devido aos altos níveis de enzimáticos produzidos, especialmente poligalacturonases, e a pouca informação sobre esta enzima deste fungo na literatura. Poligalacturonases são secretadas principalmente a partir do $2^{\circ}$ e $3^{\circ}$ dia de cultivo sob agitação, mas em maior quantidade no $9^{\circ}$ dia em regime estacionário. As condições padrões de cultura submersa foram com meio 
Czapeck, inoculado com $5 \times 10^{4}$ esporos/mL, pH inicial 6,0, sob agitação, por 48 horas. As melhores fontes de carbono foram diferentes tipos de pectinas (especialmente $2,0 \%$ de pectina 8003 CPKelco), acompanhada por casca de laranja e maracujá. Em relação à fermentação em substrato sólido, a melhor produção ocorreu com pectina caramelizada Vetec $₫$ e casca de limão. Poligalacturonases brutas apresentaram excelente estabilidade a $60^{\circ} \mathrm{C}$, por 90 minutos, e em $\mathrm{pH}$ ácido. Esta atividade foi $96 \%$ inibida por $10 \mathrm{mM} \mathrm{de} \mathrm{Hg}^{++}$e $77 \%$ por $\mathrm{Cu}^{++}$. Em contrapartida, $1 \mathrm{mM} \mathrm{Mn}^{++}$e EDTA aumentaram a atividade $17 \%$ e $10 \%$, respectivamente. A temperatura ótima da pectina liase bruta foi $55^{\circ} \mathrm{C}$.

Duas poligalacturonases (PGPI e PGPII) foram caracterizadas utilizando processos cromatográficos. PGPI foi purificada, utilizando coluna de DEAE-celulose, seguida de Biogel P100, com fator de purificação de 17 vezes. A purificação foi confirmada por SDS-PAGE, onde foi observado homogeneidade eletroforética. PGPII apresentou duas bandas em SDDS-PAGE e não foi caracterizada. A massa molecular da PGPI foi $123 \mathrm{kDa}$ por SDS-PAGE, mas 102kDa por coluna Bio-Sil-Sec-400, com 0,7x30cm, em FPLC BioRad model 2800-Solvent Delivery System. A enzima possui 37,7\% de conteúdo de carboidrato e ponto isoelétrico de 5,4. O produto final formado pela ação da PGPI em polipectato de sódio foi somente ácido monogalacturônico, sendo desta maneira classificada como uma exopoligalacturonase. Sua temperatura ótima e $\mathrm{pH}$ foram em torne de $50^{\circ} \mathrm{C}$ e numa faixa de 4,0 - 6,5, respectivamente. Apresentou alta estabilidade térmica acima de $50^{\circ} \mathrm{C}$ e foi extremamente estável numa faixa de $\mathrm{pH} 4,0-8,0$, por 24 horas. A enzima foi ativada por $\mathrm{Mn}^{++}, \mathrm{F}^{-}$e $\mathrm{K}^{+}$e inibida por $\mathrm{Pb}^{++} \mathrm{e} \mathrm{Ba}^{++}$. $\mathrm{O} \mathrm{K}_{\mathrm{m}}$ foi $6,7 \mathrm{mg} / \mathrm{mL}$ e $\mathrm{V}_{\max }$ de 230U/mg com substrato polipectato de sódio SIGMA. Ainda, a PGPI possui homologia com exopoligalacturomases de Aspergillus fumigatus e Neosartorya fischeri. A atividade não foi afetada por tolueno, n-hexano, benzeno e éter etílico, mas foi inibida por formaldeído e isopropanol.

Estes resultados mostram o potencial desta enzima para aplicação industrial quando se utiliza diferentes pHs ou solventes orgânicos em processos de produção, como na indústria de sucos e bebidas ou na extração de produtos naturais de plantas.

\section{INVESTIGAÇÃO DO SISTEMA PECTINOLÍTICO PRODUZIDO PELO FUNGO Paecilomyces variotii: PRODUÇÃO, PURIFICAÇÃO E CARACTERIZAÇÃO BIOQUÍMICA DE UMA POLIGALACTURONASE}

\section{André Ricardo de Lima Damásio}

Orientadora: Prof. Dra. Maria de Lourdes T. de M. Polizeli

Dissertação de Mestrado apresentada em 29/02/2008

As enzimas pectinolíticas são produzidas principalmente por fungos filamentosos, podendo ser classificadas em esterases (pectinesterase) e despolimerases (poligalacturonases e liases), sendo que apresentam um alto potencial de uso biotecnológico na extração de azeite de oliva, recuperação de óleos da casca de frutas, clarificação de sucos de fruta, fabricação do vinho e indústria textil. O objetivo inicial deste trabalho foi selecionar fungos bons produtores de pectinases, isolados de amostras de solo ou plantas de várias regiões do Estado de São Paulo, de acordo com o Programa BIOTA, destacando-se Paecilomyces variotii. As condições para produção enzimática foram determinadas, utilizando o meio de cultivo Czapeck, pH 7,0, suplementado com pectina cítrica $1,25 \%$ como fonte de carbono, inoculado com $10^{5}$ esporos, a $30^{\circ} \mathrm{C}$, sem agitação, por 5 dias. $\mathrm{O}$ fungo se desenvolveu em uma ampla faixa de $\mathrm{pH}$ (3-8), concentração osmótica $(0-2,5 \% \mathrm{NaCl})$, e temperatura de até $40^{\circ} \mathrm{C}$, o que o caracteriza como um microrganismo tolerante a ambientes extremos.

O processo de purificação foi realizado através de cromatografia de troca iônica (DEAE-Fractogel) e cromatografia de filtração (Sephadex G-100), onde obteve-se uma única forma de poligalacturonase, com fator de purificação de 10,1 vezes e $47,2 \%$ de recuperação.

O grau de homogeneidade foi verificado em PAGE $12 \%$ e o caráter pectinolítico foi confirmado após revelação dos géis, polimerizados com polipectato de sódio, com vermelho de rutênio. A característica de exo-poligalacturonase foi determinada através de cromatografia em camada delgada. A exo-poligalacturonase apresentou massa molecular de 79,4 kDa, com pH e temperatura ótima de reação de 4,0 e $65^{\circ} \mathrm{C}$. A enzima foi estável até $50^{\circ} \mathrm{C}$ a uma faixa de $\mathrm{pH}$ de $3,0-6,0$, por até 24 horas. O ponto isoelétrico e o conteúdo de carboidratos foram de 4,37 e 25\%, assim como, os valores aparentes de $\mathrm{Km} \mathrm{e}_{\text {máx }}$ foram de $1,84 \mathrm{mg} / \mathrm{mL}$ e $432 \mu \mathrm{mols}$ açúcares redutores/min/mg prot. Os ensaios enzimáticos na presença de diversos íons metálicos resultaram na redução da atividade enzimática na presença dos compostos $\mathrm{AgNO}_{3}(1 \mathrm{e} 10 \mathrm{mM}), \mathrm{Fe}_{2} \mathrm{SO}_{4} \cdot 4 \mathrm{H}_{2} \mathrm{O}(1 \mathrm{mM}), \mathrm{ZnCl}_{2}(10 \mathrm{mM})$, $\mathrm{AlCl}_{3}(10 \mathrm{mM})$. Na presença de solventes orgânicos, miscíveis ou imiscíveis em água, a atividade enzimática relativa manteve-se sempre acima de $70 \%$. A exo-poligalacturonase também manteve $89,6 \%$ de sua atividade na presença de $\mathrm{NaCl}$ 0,5M no meio reacional.

Através de análises em Western Blotting foi possível determinar pouca homologia entre as poligalacturonases produzidas por Paecilomyces variotii e Aspergillus niveus. 


\section{DOMÍNIOS NUCLEARES ASSOCIADOS A FBXO25: UMA NOVA ESTRUTURA SUBNUCLEAR}

\author{
Adriana Oliveira Manfiolli \\ Orientador: Prof. Dr. Marcelo Damário Gomes \\ Dissertação de Mestrado apresentada em 14/03/2008
}

O sistema ubiquitina-proteassoma (SUP) é responsável pela degradação da maioria $(80 \%)$ das proteínas intracelulares em eucariotos. Proteínas destinadas à degradação pelo SUP são primeiramente ligadas covalentemente a uma cadeia de ubiquitina, uma proteína de 76 resíduos de aminoácidos, a qual marca essas proteínas para rápida degradação pelo proteassoma $26 \mathrm{~S}$. A seletividade e a regulação da degradação específica do substrato são determinadas pelas enzimas ubiquitina ligase (E3), uma vez que são as responsáveis pelo reconhecimento do substrato. Neste trabalho foi realizada a caracterização da distribuição subcelular da E3 ligase FBXO25.

Por experimentos de imunocitoquímica e bioquímica (fracionamento celular) foi mostrado que a proteína FBXO25 endógena apresenta localização nuclear, com distribuição nucleoplasmática e exclusa do nucléolo. Além disso, verificou-se no núcleo a presença de corpos subnucleares enriquecidos da proteína FBXO25. Tais corpos parecem estar associados à estrutura da cromatina e estão presentes apenas na fase $\mathrm{G} 1 /$ telófase do ciclo celular.

Através de experimentos de imunofluorescência com dupla-marcação foi visto que os corpos de FBXO25 apresentam localização e morfologia diferentes quando comparado aos outros domínios nucleares já bem caracterizados, incluindo os speckles, corpos de Cajal, gems e clastossomos. Sendo assim, os corpos de FBXO25 foram nomeados como "FANDs" (BBXO25 Associated Nuclear Domains).

Interessantemente, a inibição da transcrição por actinomicina D ou tratamento de heat-shock provocou a redistribuição dos FANDs para o nucleoplasma, indicando que estes corpos são estruturas dinâmicas influenciadas pela atividade transcricional da célula. Entretanto, ensaios de transcrição por incorporação in vivo de Br-UTP mostraram que os corpos de FBXO25 não se concentram em sítios ativos de transcrição no núcleo.

\section{CLÍNICA CIRÚRGICA}

\section{NITRITO DO CONDENSADO EXALADO PULMONAR E NITRITO PLASMÁTICO. ESTUDO COMPARATIVO NOS PERÍODOS PRÉ E PÓS-OPERATÓRIO DE PACIENTES SUBMETIDOS À CIRURGIA CARDÍACA COM CIRCULAÇÃO EXTRACORPÓREA}

\section{Viviane dos Santos Augusto \\ Orientador: Prof. Dr. Paulo Roberto Barbosa Évora \\ Dissertação de Mestrado apresentada em 23/01/2008}

Contexto e Objetivos. O óxido nítrico (NO) é uma molécula essencial nafisiologia do corpo humano, com papel importante na regulação do tônus da musculatura lisa presente nos vasos sangüíneos pulmonares, mas o impacto do NO na função cardíaca vem sendo reconhecido recentemente. O NO exalado tem sido considerado como um potencial biomarcador de lesão pulmonar após a cirurgia cardíaca com circulação extracorpórea e observa-se um aumento do interesse no uso do condensado exalado pulmonar (CEP) como um método não-invasivo para investigar doenças pulmonares. O objetivo desse estudo, prospectivo e não randomizado, foi verificar associações entre os níveis de nitrito $\left(\mathrm{NO}_{2}{ }^{-}\right)$no plasma e no condensado do exalado pul- monar (CEP) nos períodos pré e pós-operatório tardio (24h) de cirurgia cardíaca com circulação extracorpórea.

Métodos. Foram selecionadas 28 pacientes adultos de ambos os sexos, com idade entre 26 e 71 anos, subdivididos em dois grupos: 1) controle (não cirúrgico) e 2) cirúrgico (cirurgia valvar e revascularização do miocárdio). $\mathrm{O}$ CEP e amostras sanguíneas de cada um dos pacientes, foram armazenados e congelados a $-70^{\circ} \mathrm{C}$. As dosagens de nitrito plasmático no CEP foram realizadas pelo método quimioluminescência (Nitric Oxide Analyzer, 280i, da marca SIEVERS- NOA-Sievers). Os dados foram apresentados como média e desvio-padrão, e a análise estatística utilizou os testes não-paramétricos Mann-Whitney e Wilcoxon.

Resultados. Os resultados principais obtidos foram: a) os níveis de $\mathrm{NO}_{2}{ }^{-}$do CEP, coletado com gelo seco, no grupo cirúrgico pré-operatório foram superiores aos do grupo controle coletados pelo mesmo método $(\mathrm{p}<0,05)$ em paci- 
entes do grupo controle; $b$ ) as concentrações de $\mathrm{NO}_{2}{ }^{-}$do CEP no grupo pré-operatório de correção valvar foram maiores do que no período pós-operatório $24 \mathrm{~h}(\mathrm{p}<0,05)$, coletados através do resfriamento com gelo seco; c) não foram encontrados valores com significância estatística para as concentrações de $\mathrm{NO}_{2}{ }^{-}$plasmático comparando-se o grupo controle, cirurgia de correção valvar e revascularização do miocárdio no período pré-operatório; d) houve aumento do $\mathrm{NO}_{2}{ }^{-}$ plasmático comparando-se os períodos pré e pós-operató- rio 24h do grupo de cirurgia de revascularização do miocárdio $(\mathrm{p}<0,05)$; e) não foram observadas correlações entre os níveis de $\mathrm{NO}_{2}$ - plasmático e os níveis de $\mathrm{NO}_{2}{ }^{-}$do CEP.

Conclusões: Os resultados da investigação sugerem que a dosagem de nitrito no CEP é viável, de fácil colheita e se presta para estudos clínicos experimentais. A não correlação com os valores de nitrito plasmático venoso sugere que o NO exalado possa refletir mais a formação local do que sistêmica.

\section{ESTUDO DO EFEITO DA N-ACETILCISTEÍNA NAS DISFUNÇÕES DO ENDOTÉLIO E DA MUS- CULATURA LISA VASCULAR DE RATOS DIABÉTICOS}

\section{Verena Kise Capellini}

Orientador: Prof. Dr. Alfredo José Rodrigues

Dissertação de Mestrado apresentada em 25/01/2008

As anormalidades metabólicas que acompanham o diabetes são complexas e promovem, direta ou indiretamente, múltiplas disfunções, dentre elas as disfunções do endotélio e da musculatura lisa vascular. Aponta-se para o estresse oxidativo como o mecanismo responsável pela ocorrência de muitas destas disfunções, sendo, portanto, cabível considerar as terapias antioxidantes no diabetes.

A N-acetilcisteína (NAC) é uma droga antioxidante e esta atividade relaciona-se principalmente com a liberação de grupos sulfidril, com a síntese de glutationa reduzida e com o seqüestro de radicais livres.

O objetivo deste estudo foi verificar se o tratamento com NAC foi capaz de atenuar as alterações bioquímicas plasmáticas, morfométricas, imuno-histológicas e funcionais vasculares em modelo experimental de diabetes induzido por aloxana em ratos. Para tanto, ratos Wistar machos foram divididos em 3 grupos: controle (C), diabetes (D) e diabetes tratado (DT).

O estudo teve duração de 5 semanas. $\mathrm{Na} 1^{\mathrm{a}}$ semana, foi induzido diabetes nos grupos D e DT com uma injeção de $40 \mathrm{mg}$ de aloxana/kg de peso corporal. Da $2^{\mathrm{a}}$ a $5^{\mathrm{a}}$ semana, os ratos permaneceram em gaiolas metabólicas, foi administrado, via oral, 1,3 g de NAC/kg de peso corporal/dia para cada animal do grupo DT, e foram aferidos os seguintes parâmetros: glicemia, semanalmente, e peso corporal, ingestão hídrica, ingestão alimentar e diurese, diariamente. No final da $5^{\mathrm{a}}$ semana, os ratos foram sacrificados para coleta de sangue e da aorta torácica. Foram analisados os níveis plasmáticos de malondialdeído (MDA) e nitrito + nitrato (NOx) e foram realizados estudos imunohistoquímico, morfométrico e de reatividade vascular com a aorta torácica. $\mathrm{O}$ modelo experimental foi efetivo na indução do diabetes, visto que os ratos dos grupos D e DT apresentaram hiperglicemia, perda de peso, polidipsia, polifagia e poliúria. Verificouse também que a área e a espessura da camada muscular da aorta dos ratos dos grupos D e DT foram menores, o que se associa ao estado caquético destes animais. Entretanto, não foram observadas alterações significativas nos níveis plasmáticos de MDA entre os grupos. O NOx plasmático foi significativamente maior no grupo DT, fato que pode relacionar-se com a formação de S-nitrosotióis. Apesar da redução na marcação da sintase do óxido nítrico endotelial na camada endotelial da aorta dos animais dos grupos D e DT, não houve alterações no relaxamento dependente do endotélio nestes animais. O relaxamento independente do endotélio e a contração induzida por fenilefrina também não apresentaram diferenças significativas entre os grupos.

Portanto, o tratamento com NAC não atenuou as alterações morfométricas e imunohistoquímicas em aortas de ratos diabéticos. Contudo, não foi possível verificar se este tratamento é capaz de atenuar as alterações bioquímicas plasmáticas e funcionais vasculares em ratos diabéticos.

\section{EFEITOS DAS ALTERAÇÕES DA VENTILAÇÃO MINUTO SOBRE AS VARIÁVEIS OBTIDAS PELA CALORIMETRIA INDIRETA EM PACIENTES EM ESTADO CRÍTICO}

Franciele Cristina Meirelis Clapis

Orientador: Prof. Dr. Anibal Basile Filho

Dissertação de Mestrado apresentada em 31/01/2008
Racional e Objetivos. O calorímetro é um aparelho que conectado ao ventilador mecânico de pacientes em estado crítico, determina as necessidades nutricionais através 
das medidas de consumo de oxigênio $\left(\mathrm{VO}_{2}\right)$ e produção de gás carbono $\left(\mathrm{VCO}_{2}\right)$. Atualmente a calorimetria indireta $(\mathrm{CI})$ tem sido muito aplicada para estudar a fisiologia pulmonar em pacientes sob assistência ventilatória mecânica. O objetivo desse estudo foi caracterizar a resposta do $\mathrm{VO}_{2}, \mathrm{VCO}_{2}$, quociente respiratório (QR) e gasto energético (GE), após mudanças bem definidas na VE (ventilação minuto) ( $\pm 20 \%$ ) durante três horas e setenta e cinco minutos em pacientes graves.

Pacientes e métodos. Realizou-se um estudo prospectivo e autocontrolado de CI em 20 pacientes graves, sob assistência ventilatória mecânica em modo volume controlado $(n=15)$ ou pressão controlada $(n=5)$. Todos os pacientes estavam sedados, sem nenhuma respiração espontânea e estáveis sob o ponto de vista hemodinâmico, o qual forneceu dados de $\mathrm{VO}_{2}, \mathrm{VCO}_{2}$, VE, GE, QR. Realizaram-se três medidas de CI de 45 min cada. Na última medida a VE era ajustada cerca de $20 \%$ acima do valor basal.

Resultados. Comparando as variáveis obtidas pela calorimetria antes e após a intervenção, observou-se um aumento significativo do $\mathrm{VCO}_{2}\left(165 \mathrm{~mL} \cdot \mathrm{min}^{-1}\right.$ para 177,75 $\left.\mathrm{mL} \cdot \mathrm{min}^{-1}, \mathrm{p}<0,01\right)$, associado a uma queda também signifi- cativa da $\mathrm{PaCO}_{2}(38,49 \mathrm{mmHg}$ para $28,46 \mathrm{mmHg}, \mathrm{p}<0,01)$ e uma alteração do $\mathrm{pH}(7,41$ para $7,49, \mathrm{p}<0,01)$. Pouca alteração foi observada nas medidas de $\mathrm{VO}_{2}, \mathrm{GE}$ e QR.

Conclusões. Os resultados do presente estudo nos permitem concluir, pelo menos sob o ponto de vista estatístico, que pequenas mudanças na ventilação minuto provocam alterações nas variáveis obtidas pela CI, sobretudo do $\mathrm{VCO}_{2}$, desproporcional em relação às medidas de $\mathrm{VO}_{2}$. Este achado pode caracterizar uma maior eliminação do $\mathrm{CO}_{2}$ do seu pool metabólico através dos pulmões, oriundo provavelmente do $\mathrm{CO}_{2}$ dissolvido no sangue, devido à hiperventilação provocada. A alteração discreta do $\mathrm{VO}_{2}$ e $\mathrm{GE}$ nos leva a concluir que o aumento da VE pouco interfere nessas variáveis. Esse aumento do VE desencadeou uma alteração no equilíbrio ácido-base por provocar uma maior eliminação de $\mathrm{CO}_{2}$. No entanto, parece que estas alterações são temporárias, sem repercussões clínicas importantes e completamente reversíveis, se a duração do tempo de aumento do VE for inferior a 45 minutos. As medidas de calorimetria indireta não sofreram interferência em função dos ventiladores e modos ventilatórios utilizados em nosso estudo.

\section{ESTUDO DO NITRITO DO CONDENSADO DO EXALADO PULMONAR. PADRONIZAÇÃO DE MÉTODO}

\section{Graziela Saraiva Reis}

Orientador: Prof. Dr. Paulo Roberto Barbosa Evora

Dissertação de Mestrado apresentada em 01/02/2008

Contexto e Objetivos. O óxido nítrico (NO) é uma molécula essencial na fisiologia do corpo humano, com papel importante na regulação do tônus da musculatura lisa presente nos vasos sangüíneos pulmonares, mas o impacto do NO na função cardíaca vem sendo reconhecido recentemente. O NO exalado tem sido considerado como um potencial biomarcador de lesão pulmonar após a cirurgia cardíaca com circulação extracorpórea e observa-se um aumento do interesse no uso do condensado exalado pulmonar (CEP) como um método não-invasivo auxiliar na investigação doenças pulmonares e elemento orientador no tratamento de tais patologias. Assim, o objetivo dessa investigação foi a padronização de uma técnica simples e barata de coleta do CEP para dosagem de NO.

Métodos. Para a coleta do CEP foram montados 2 dispositivos em caixas de isopor (medidas das caixas: $26 \mathrm{~cm}$ de comprimento e $16,5 \mathrm{~cm}$ de largura), para testar a metodologia. Um bocal foi adaptado ao circuito, para o indivíduo respirar seu volume corrente (VC) através dele. Após a acomodação de cada circuito dentro de cada caixa de isopor, foi colocado em seu interior para a condensação do ar exalado gelo picado/sal grosso (proporção de 6 partes de gelo para 3 partes de sal grosso) ou gelo seco com gelo picado, sendo que o gelo seco foi acondicionado em uma caixa plástica, ficando separado do gelo picado. A temperatura ficou em torno de $-10^{\circ} \mathrm{C}$ no dispositivo com gelo seco e gelo picado, e $-15^{\circ} \mathrm{C}$ no dispositivo com gelo picado/sal grosso. O CEP e amostras sanguíneas de cada um dos pacientes, foram armazenados e congelados a $-70^{\circ} \mathrm{C}$. As dosagens de nitrito no CEP foram realizadas por quimioluminescência e pelo método de Griess. Os dados foram apresentados como média e desvio-padrão, e a análise estatística utilizou os testes não-paramétricos Mann-Whitney e Wilcoxon.

Resultados. a) A utilização do gelo seco e do gelo picado/sal grosso mostrou-se bastante efetiva na coleta do condensado do ar exalado em ambos os grupos, quando estão em ar ambiente. Já durante o período de assistência ventilatória a metodologia utilizada foi pouco eficiente; $b$ ) O método gelo picado/sal grosso coletou maior volume de condensado intragrupo e intergrupos; no entanto, os níveis de nitrito $\left(\mathrm{NO}_{2}^{-}\right)$exalado em valores absolutos não foram maiores no grupo em que a coleta foi feita utilizando esse método; c) Os níveis de $\mathrm{NO}_{2}{ }^{-}$exalado em valores absolutos foram maiores no grupo cirúrgico em ambos os métodos de coleta; d) No grupo cirúrgico o uso do clipe nasal diminuiu a concentração de $\mathrm{NO}_{2}{ }^{-}$exalado nos dois métodos, mas o mesmo não foi visto no grupo não cirúrgico, tendo aumento das concentrações de $\mathrm{NO}_{2}{ }^{-}$exalado quando usamos o clipe nasal; e) Os níveis de $\mathrm{NO}_{2}{ }^{-}$exalado 
nos indivíduos que foram operados numa temperatura normotérmica $\left(34^{\circ} \mathrm{C}\right)$ diminuíram no pós-operatório 24 horas quando comparados ao período pré-operatório. Tal fato foi observado para os dois métodos de coleta; Já para pacientes operados a $28^{\circ} \mathrm{C}$, não foi possível realizar análise estatística, devido ao pequeno número de amostras.

Conclusões. a) A metodologia utilizada para mensuração de $\mathrm{NO}_{2}{ }^{-}$no condensado exalado foi válida para indivíduos que se encontram em ar ambiente, obtendo sucesso nas coletas realizadas tanto com gelo seco quanto com gelo picado/sal grosso, mostrando que é possível diminuir o custo benefício dessa metodologia; b)Dentre os dois métodos utilizados, aquele que fez uso de gelo picado/sal grosso mostrou-se mais eficiente em relação ao volume de condensado coletado, quando comparado ao método do gelo seco; c) Já em relação ao período em que os pacientes se encontram em ventilação mecânica, o condensado exalado não foi coletado para todos os indivíduos, devido a problemas com a temperatura de congelamento ou até mesmo com a própria metodologia, necessitando de mais estudos nessa área para que se descubra o melhor método de coleta durante a assistência ventilatória.

\section{CLÍNICA MÉDICA}

\section{MODULAÇÃO DA VIA DE SINALIZAÇÃO DO TGFß E DO VEGF PELA ONCOPROTEÍNA PML-RARK}

\section{Lorena Lobo de Figueiredo Pontes}

Orientador: Prof. Dr. Eduardo Magalhães Rego

Tese de Doutorado apresentada em 11/01/2008

Embora o TGF $\beta$ atue como supressor tumoral no início da tumorigênese, a progressão neoplásica freqüentemente se acompanha de responsividade alterada ao TGF $\beta$ e aumento da angiogênese. A leucemia promielocítica aguda (LPA) caracteriza-se por rearranjo dos genes PML e RAR $\alpha$ nos cromossomos 15 e 17, respectivamente. A expressão do $\mathrm{PML} / \mathrm{RAR} \alpha$ está associada à resistência às ações do TGF $\beta$, que também regula a expressão gênica e protéica do VEGF. A halofuginona (HF) é um alcalóide capaz de regular o TGFâ e reduzir a angiogênese em tumores não hematopoéticos. Neste trabalho, objetivamos estudar na LPA: (1) a angiogênese mediada pelo TGF $\beta$ e VEGF; (2) a interação entre a via do TGF $\beta$ e a presença do PML-RAR $\alpha$ e (3) os efeitos da HF nas linhagens NB4 e NB4-R2. A análise do TGF $\beta$ por western blot mostrou maior expressão desta proteína em células leucêmicas do que em células normais da medula óssea (MO). A quantificação, por ELISA, do TGF $\beta$ e, por citometria de fluxo (CMF), de VEGF e angiogenina mostrou que as células leucêmicas secretam altos níveis desses fatores angiogênicos. A imunohistoquímica da MO de camundongos leucêmicos PML-RARk revelou aumento da densidade microvascular e do VEGF em relação aos animais selvagens. Um modelo condicional retroviral no qual a expressão do PMLRARk é regulada pela tetraciclina foi gerado em precursores hematopoéticos da MO murina, submetidos ao trata- mento com doxiciclina e/ou HF durante 72 horas. Na presença do PML-RARk, o Tgf $\beta$ se encontrou reprimido, resultando em regulação positiva do c-Myc, sendo este efeito acentuado pelo tratamento das células com HF. Células NB4 e NB4-R2, esta última resistente ao ATRA, foram cultivadas sob doses crescentes de $\mathrm{HF}(6,25$ a $100 \mathrm{ng} / \mathrm{mL})$ e/ou ATRA $10^{-6} \mathrm{M}$ durante 72 horas. A HF inibiu o crescimento celular de maneira dose-dependente a partir de 24 horas do tratamento $(\mathrm{P}<0,001)$. A análise por $\mathrm{CMF}$ da marcação com Anexina V / iodeto de propídeo e bromodeoxiuridina / BCL2 mostrou um aumento progressivo da apoptose e bloqueio do ciclo celular na transição G1/S concomitante à redução de BCL-2 (P<0,001). A HF também levou ao aumento da expressão protéica de TGF $\beta$ e SMAD4 nos extratos nucleares das células NB4 e à redução da produção de TGF $\beta$, VEGF e angiogenina (nesta última, $\mathrm{P}<0,001$ ) em altas doses. A análise da expressão de genes-alvo do TGFâ em resposta à HF por meio de PCR em Tempo Real mostrou aumento de TGF $\beta$, T $\beta$ RI, P15, P21 ( $\mathrm{P}<0,001)$ e SMAD3 ( $\mathrm{P}=$ $0,001)$ e repressão do c-MYC $(\mathrm{P}<0,001)$ em ambas as linhagens. Os resultados mostram que na LPA: (1) a angiogênese está aumentada; (2) a regulação dos genes-alvo do TGF $\beta$ é dependente do PML-RARk; e (3) a HF teve efeitos antiproliferativos e antiangiogênicos, revertendo o bloqueio da sinalização do TGFâ. Embora a desregulação das vias do TGF $\beta$ e VEGF não seja suficiente para iniciar a transformação maligna, esta pode ser um segundo evento que contribui para a progressão leucêmica. Nesse contexto, a modulação da sinalização do TGF $\beta$ e da angiogênese pode ter potencial terapêutico na LPA. 


\section{NUTRIÇÃO PARENTERAL E AVALIAÇÃO MICROBIOLÓGICA DE CATETERES VENOSOS CEN- TRAIS, POR MEIO DE MICROSCOPIA ELETRÔNICA DE VARREDURA}

\section{Juliana de Carvalho Machado}

Orientador: Prof. Dr. Júlio Sérgio Marchini

Dissertação de Mestrado apresentada em 16/01/2008

O uso de cateteres venosos centrais (CVC) está amplamente difundido na prática clínica, pois possibilita a administração de nutrientes, medicamentos, hemoderivados como também, a monitorização clínica de pacientes críticos. Porém, não está isento de complicações médicas e a infecção relacionada ao seu uso é uma das mais freqüentes e temidas. A Divisão de Nutrologia do Hospital das Clínicas da Faculdade de Medicina de Ribeirão Preto é responsável pela equipe de Terapia Nutricional deste serviço atendendo pacientes que necessitam, por algum motivo, de nutrição parenteral. Como a maioria destes pacientes é desnutrida, a infecção relacionada ao cateter é fator complicador importante e algumas vezes é assintomática. O objetivo deste estudo foi, então, mostrar, através do método de microscopia eletrônica de varredura (MEV), a presença de microorganismos aderidos ao lúmen do $\mathrm{CVC}$ utilizados para terapia nutricional parenteral. Esta colonização do CVC pode determinar e manter o quadro infeccioso, nem sempre diagnosticado. Foram analisados, através de cultura semiquantitativa e de MEV, um total de 39 CVC, pertencentes aos seguintes grupos: grupo 1 (pacientes com sinais clínicos de infecção); grupo 2 (pacientes assintomáticos), grupo 3 (monitorização clínica) e grupo 4 (sem uso clínico). Apesar do grupo 1 apresentar culturas semiquantitativas mais positivas do que as do grupo 2 e 3 ( $81 \%$ versus $50 \%$ e $0 \%$, respectivamente), observamos, porém, que houve formação de biofilmes em todos os cateteres utilizados clinicamente e, destes, 55\% tinham estruturas biológicas que sugeriam colonização dos cateteres por microorganismos. Aproximadamente $53 \%$ das infecções dos cateteres estavam relacionadas com infecções sistêmicas, confirmadas por hemoculturas. A aderência de microorganismos ao lúmen do cateter é frequiente e acarreta aumento na morbidade dos pacientes, principalmente, naqueles imunodeprimidos e que necessitam de um acesso venoso central para terapia nutricional. São necessários técnicas de assepsia eficientes para o manuseio destes cateteres, além de técnicas que combatam ou impeçam a formação de biofilmes.

\section{PRESENÇA DOS VÍRUS HBV E HCV E SEUS FATORES DE RISCOS NOS PRESIDIÁRIOS MAS- CULINOS DA PENITENCIÁRIA DE RIBEIRÃO PRETO}

\section{Harnoldo Colares Coelho}

Orientador Prof. José Fernando de Castro Figueiredo

Tese de Doutorado apresentada em 01/02/2008

Infecções pelos vírus da hepatite $\mathrm{B}(\mathrm{HBV})$ e vírus da hepatite $\mathrm{C}(\mathrm{HCV})$ na população prisional apresentam prevalências bastante elevadas, alcançando taxas, algumas vezes, de mais de $40 \%$. Contribuem para isso diversos comportamentos de risco, adotados já antes do encarceramento ou desenvolvidos durante o período de reclusão. Entre eles, destacam-se o uso de drogas ilícitas intravenosas com compartilhamento de agulhas, tatuagens e atividade sexual desprotegida. Esta pesquisa objetivou estimar a prevalência dos marcadores do HBV e HCV com seus respectivos fatores de risco para estas exposições na população masculina carcerária da Penitenciária de Ribeirão Preto - SP, no período de maio a agosto de 2003. Do total de 1030 presidiários, foram sorteados 333 participantes por amostragem casual simples, os quais foram submetidos à aplicação de um questionário padronizado e tiveram coletada uma amostra de sangue. Para diagnóstico do HBV e HCV foi utilizado o ensaio imunoenzimático para detecção do HBsAG, anti-HBc total, anti-HBs e anti-HCV. A confirmação deste foi feita através de reação de polimerase em cadeia (HCV RNA). As prevalências encontradas para $\mathrm{HBV}$ e HCV nos presidiários foram de 19,5\% ( $\mathrm{IC}_{95 \%}: 15,2$ - 23,8) e 8,7\% $\left(\mathrm{IC}_{95 \%}: 5,7-11,7\right)$, respectivamente. Todas as variáveis que apresentaram “p” abaixo de 0,25, através de análise univariada, foram submetidas a um modelo multivariado de regressão logística. Nesta análise, as variáveis que se mostraram preditoras de forma independente da infecção pelo HBV foram: idade acima de 30 anos e passado de droga injetável. Já para o HCV, as variáveis foram idade acima de 30 anos, história prévia de hepatite, tatuagem, passado de droga injetável e passado de compartilhamento de agulhas.

\section{ALTERAÇÕES HEPÁTICAS PROVOCADAS PELO CONSUMO CRÔNICO DE ETANOL: AÇÃO DA VITAMINA E OU DA LECITINA DE SOJA}

\section{Sheila Cristina Lima Sanches}

Orientador: Prof. Dr. Alceu Afonso Jordão Jr. Dissertação de Mestrado apresentada em 01/02/2008
A ingestão crônica de etanol pode ocasionar uma série de doenças hepáticas em um processo de estresse oxidativo relacionado com a formação de radicais livres, 
assim é importante conhecer os compostos que agem como antioxidantes e sua atuação nos efeitos deletérios. A vitamina E é considerada o principal antioxidante lipossolúvel nas membranas celulares, favorecendo contra o processo de peroxidação lipídica. A lecitina de soja, por meio de um de seus componentes mais ativos, a polienilfosfatidilcolina (PFC) equilibra o estresse oxidativo, e pela a fosfatidilcolina, composto lipoprotéico mais importante das membranas, atua de forma protetora contra a esteatose. Este trabalho avaliou os danos causados ao fígado pelo consumo crônico de etanol e os efeitos da vitamina E e da lecitina de soja na dieta sobre a taxa de lipoperoxidação e esteatose alcoólica. Foram usados 78 ratos Wistar, machos, divididos em seis grupos: Grupo C (dieta controle e água); Grupo CE (dieta controle e solução hidroalcoólica 20\%); Grupo LS (dieta com lecitina de soja 5\% e água); Grupo LSE (dieta com lecitina de soja $5 \%$ e solução hidroalcoólica 20\%); Grupo Vit. E (dieta com vitamina E 0,6\% e água); e Grupo EE (dieta com vitamina E $0,6 \%$ e solução hidroalcoólica $20 \%$ ). Estes ratos receberam as dietas e as soluções hidroalcoólicas por 28 dias e no final do experimento foram sacrificados. Foram realizadas dosagens bioquímicas sanguíneas das transaminases, proteínas totais e carbonil, dosagens hepáticas de MDA, GSH, Vitamina E e gorduras totais, e realizadas análises histopatológicas para a avaliação de esteatose hepática. As comparações estatísticas entre grupos foram feitas por análise de variância (ANOVA), utilizando o teste de Tukey e análise qualitativa pelo teste qui-Quadrado, considerando significativas as diferenças com $\mathrm{p}<0,05$. Os resultados observados nos cortes histopatológicos mostraram que os grupos tratados com lecitina de soja e vitamina E tiveram menor grau de esteatose. Nas dosagens das transaminases não foram observadas diferenças. As dosagens de gorduras totais mostraram diferenças entre os grupos CE $(141,43 \pm 22,83)$ e LSE $(106,92 \pm 17,95)$, mostrando o papel protetor da lecitina de soja contra a esteatose. A concentração de MDA foi significativamente menor no Grupo EE $(0,09 \pm 0,01)$ em relação aos outros grupos, mostrando o papel protetor da vitamina E contra a peroxidação lipídica. Os níveis de concentrações plasmáticas do grupo Carbonil foram menores nos grupos tratados com lecitina de soja e diferentes dos outros grupos, concluindo que a lecitina de soja agiu contra o processo de oxidação protéica. Os níveis de vitamina $\mathrm{E}$ foi significativamente maior nos grupos Vit. $\mathrm{E}$ $(459,18 \pm 430,14)$ e EE $(837,56 \pm 438,76)$, resultado atribuído à propriedade lipossolúvel da vitamina E. A concentração de GSH foi maior no Grupo C apresentando diferenças significativas em relação aos grupos LS, LSE, Vit E e EE, conferindo à GSH um papel protetor contra os efeitos pró-oxidantes da vitamina E. De acordo com os resultados obtidos, atribuiu-se funções protetoras para a vitamina E no processo de peroxidação lipídica, apresentando função antioxidante, e para a lecitina de soja na esteatose hepática, conhecida por ser o primeiro estágio de doenças hepáticas, consideradas assim, protetoras contra as doenças hepatoalocoólicas.

\section{A COLONIZAÇÃO DE SONDAS VESICAIS DE DEMORA POR Candida spp: QUANTIFICAÇÃ̃o E RELAÇÃO COM INFECÇÃO URINÁRIA EM PACIENTES HOSPITALIZADOS}

\section{Danielle Darin Dóro}

Orientador: Prof. Dr. Roberto Martinez

Dissertação de Mestrado apresentada em 14/02/2008

Quase 80\% das infecções nosocomiais do trato urinário são associadas ao uso de catéter urinário e as espécies de Candida estão entre os patógenos mais isolados, principalmente nas Unidades de Terapia Intensiva. Embora a presença de candidúria entre pacientes hospitalizados seja frequentemente reportada, o significado da presença de leveduras na urina ainda não é totalmente esclarecido, podendo representar uma infecção do trato urinário ou meramente uma colonização ou contaminação. O passo inicial no desenvolvimento da colonização é a capacidade dos microorganismos de aderir à superfície interna ou externa do cateter após a inserção, ocorrendo a formação de biofilme. O objetivo deste estudo foi avaliar a colonização por espécies de Candida de sondas vesicais de demora (SVD) utilizadas em pacientes hospitalizados, avaliando diferentes segmentos da sonda e relacionando os resultados com o isolamento de leveduras na urina e com dados do paciente e da hospitalização. Foram coletadas 52 amostras de urina e as respectivas SVD de pacientes adultos, 21 homens e 31 mulheres, sem uso de antifúngicos, internados no Hospital das Clínicas da Faculdade de Medicina de Ribeirão Preto USP. Realizou-se a secção de 5 segmentos da SVD, os quais foram sonicados em salina estéril, seguida de cultura quantitativa dessas amostras da SVD e da urina em Agar Sabouraud dextrose com cloranfenicol. Houve isolamento de leveduras do gênero Candida em 44,2\% das amostras de urina e em 50,0\% das SVD, que tinham um ou mais segmentos colonizados. Tanto na urina quanto nos cinco segmentos da SVD, Candida albicans foi a levedura mais frequentemente isolada, com 56,5\% e 61,6\% respectivamente, seguido por Candida glabrata, C. tropicalis, C. parapsilosis e C. krusei. A contagem de leveduras do gênero Candida foi significativamente superior no lúmen do primeiro segmento (proximal) da SVD do que nos quatro mais distais. Foi detectada associação entre a presença de Candida spp na urina e na SVD ( $<<0,0001)$, e também um correlação positiva entre o número de leveduras na urina e no lúmen do segmento proximal da SVD. As SVD se mos- 
traram mais colonizadas quanto maior o tempo de hospitalização do paciente $(\mathrm{p}<0,05)$ e embora o percentual de sondas colonizadas tenha crescido à medida que aumentou o tempo de cateterização, esta última associação não foi confirmada estatisticamente. A colonização da SVD foi mais freqüentemente encontrada nos pacientes com idade avançada e do sexo feminino. Esta investigação revelou uma alta prevalência de SVD colonizadas por leveduras e uma forte associação entre infecção urinária por Candida spp e colonização do lúmen da sonda vesical, que pode estar implicada na origem e na manutenção de candidíase de vias urinárias.

\section{POLIMORFISMOS DOS GENES HLA- $G$ E DE CITOCINAS EM PACIENTES COM HISTÓRICO DE CARCINOMA DE CÉLULAS TRANSICIONAIS DA BEXIGA URINÁRIA}

\section{Erick da Cruz Castelli}

Orientador: Prof. Dr. Eduardo Antônio Donadi

Tese de Doutorado apresentada em 15/02/2008

A aparência morfológica e o comportamento clínico dos carcinomas de células transicionais da bexiga urinário (CCT) provavelmente são resultado de uma complexa e contínua interação de agentes carcinogênicos e a resistência do paciente durante sua vida. O principal fator ambiental envolvido na etiologia do CCT é o tabagismo, no entanto, há poucas informações acerca da constituição genética e susceptibilidade ao CCT. Muitas linhas de evidência demonstraram que os polimorfismos do loco $H L A-G$ estão relacionados a seus níveis de expressão, padrões de edição alternativas e produção de diferentes isoformas da proteína HLA-G. A expressão de HLA-G pode influenciar a progressão tumoral por inibir a ação das células NK e T citotóxicas, promovendo um mecanismo de escape das respostas imunitárias. Ainda, as citocinas estão envolvidas nas respostas imunitárias contra neoplasias e controlam as fases efetoras das respostas a tumores e das imunoterapias. Muitos polimorfismos nos genes codificadores de citocinas foram descritos como influenciando seus níveis de expressão. O objetivo deste trabalho foi avaliar um possível papel dos polimorfismos do loco HLA-G, dos SNPs -308 e -238 do loco TNF codificador do Fator de necrose tumo- ral, do SNP -889 do loco IL1A, codificador da interleucina-1 alfa, e do SNP +874 do loco IFNG, codificador do Interferon gama, na susceptibilidade ao desenvolvimento de progressão do CCT na população brasileira, com ênfase em uma potencial influência do tabagismo nestas associações. $\mathrm{O}$ loco HLA-G demonstrou uma associação com susceptibilidade ao desenvolvimento e progressão do CCT, apresentando uma interação complexa entre gene e ambiente. $\mathrm{O}$ alelo $G^{*} 010404$ (antigamente conhecido como $\mathrm{G}^{*} 010110$ ), especialmente a proteína $\mathrm{G}^{*} 0104$, e o alelo $G^{*} 0103$ foram associados a uma influência dependente do tabagismo na susceptibilidade ao CCT. A proteína $\mathrm{G}^{*} 0104$ foi associada a tumores de alto grau independentemente do tabagismo, enquanto o alelo $G^{*} 0103$ foi associado a tumores de alto grau somente entre tabagistas. Com relação aos polimorfismos de citocinas, apenas o SNP -308 do loco TNF foi associado a tumores de alto grau, independentemente do tabagismo. Nossos resultados demonstram o efeito dos polimorfismos do complexo HLA, em especial os polimorfismo do gene de classe I não-clássico $H L A-G$ e do gene codificador do fator de necrose tumoral (TNF), localizado na região de classe III, nos mecanismos de escape tumoral das respostas imunitárias do hospedeiro e na susceptibilidade a carcinomas de alto grau. Estes polimorfismos parecem ser um componente crítico na susceptibilidade e progressão do carcinoma de células transicionais da bexiga urinária.

\section{A DEGLUTIÇÃO EM PACIENTES COM DOENÇA PULMONAR OBSTRUTIVA CRÔNICA(DPOC)}

\section{Rachel de Aguiar Cassiani}

Orientador: Prof. Dr. Roberto Oliveira Dantas

Dissertação de Mestrado apresentada em 26/02/2008

O trabalho objetivou o estudo da deglutição em pacientes com doença pulmonar obstrutiva crônica (DPOC), sendo incluídos 16 pacientes com diagnóstico de DPOC confirmado pela espirometria (idades entre 56-77 anos) e em fase estável da doença, e 15 indivíduos do grupo controle (idades entre 57-73 anos).

Os indivíduos do grupo de pacientes (DPOC) e controles responderam a um questionário a respeito de queixas da deglutição, e realizaram uma refeição padronizada de 1800 calorias. Neste momento foi observada, pelo uso do pulso oxímetro, a saturação de oxigênio no sangue e a freqüência cardíaca. Após a refeição todos os participantes do estudo foram questionados sobre a sensação de dispnéia, a qual foi pontuada por meio de uma escala numérica variando de 0 a 10.

A conformação anatômica e o comportamento funcional da deglutição foram avaliados pelo exame videofluoroscópico da deglutição, com registro na velocidade de 60 quadros por segundo. Deglutições de 5 e $10 \mathrm{~mL}$ de sulfato de bário de consistência líquida e pastosa, além de alimen- 
to de consistência sólida (bolacha) foram realizadas pelo indivíduos dos dois grupos. Este exame permitiu a observação de 20 variáveis relacionadas ao trânsito orofaríngeo, além da presença ou não de outros aspectos relacionados à função de deglutição como: penetração, aspiração, escape posterior do alimento, deglutição fracionada e resíduos faríngeos. As estruturas observadas pelo estudo videofluoroscópico foram: língua, osso hióide, laringe, faringe, esfíncter superior do esôfago, fechamento glótico, epiglote. A duração do movimento destas estruturas foi também analisada, totalizando 11 parâmetros medidos. Estes parâmetros incluíram: movimento da base da língua, duração da fase oral, trânsito faríngeo, duração do movimento do osso hióide, duração do fechamento das pregas vocais, tempo sustentados da laringe, depuração faríngea, trânsito faríngeo, trânsito pelo esfíncter superior do esôfago e trânsito orofaríngeano.

Foi observado efeito da alimentação na saturação de oxigênio $\left(\mathrm{SpO}_{2}\right)$ e na freqüência cardíaca, em ambos os grupos. No grupo controle, a $\mathrm{SpO}_{2}$ diminuiu do período antes para após a refeição $(\mathrm{p}<0,01)$ e no grupo DPOC a $\mathrm{SpO}_{2}$ diminuiu durante e após a refeição $(\mathrm{p}<0,01)$. A frequiência cardíaca foi sempre maior nos pacientes com DPOC podendo ser este fator compensatório ao comprometimento da função pulmonar. Foi observada menor ingestão de alimento nos pacientes com DPOC.

O exame videofluoroscópico da deglutição mostrou diferenças estatísticas significantes para os seguintes tempos das variáveis estudadas: trânsito faríngeo, duração do movimento do osso hióide, duração do fechamento das pregas vocais, tempo de elevação da laringe e trânsito orofaringeano $(\mathrm{p}<0,05)$. Estas diferenças foram encontradas para a consistência líquida, nos volumes de $5 \mathrm{~mL}$ e de 10 mL. A duração do movimento das estruturas ou do tempo de trânsito foi mais prolongada no grupo de doentes, com relação ao grupo controle.

Conclui-se que durante a alimentação ocorre queda na $\mathrm{SpO}_{2}$ em pacientes com DPOC em fase estável da doença. Neste trabalho, como demonstrado pelo exame videofluoroscópico da deglutição, não houve ocorrência de aspiração e/ou penetração laringotraqueal, sendo que para a consistência líquida o trânsito foi prolongado. É possível que esta tendência do trânsito orofaringeano prolongado provoque maior duração do fechamento das pregas vocais e do movimento do osso hióide, sendo estes mecanismos compensatórios para assegurar proteção das vias aéreas.

\section{EFEITOS DA SUPLEMENTAÇÃO DE COLINA E FRUTOOLIGOSSACARÍDEO NA ESTEATOSE HEPÁTICA EM RATOS WISTAR}

\author{
Nádia Juliana Beraldo Goulart Borges \\ Orientador: Prof. Dr. Júlio Sérgio Marchini \\ Dissertação de Mestrado apresentada em 27/02/2008
}

A Doença Hepática Gordurosa Não Alcoólica (DHGNA) é uma condição clínico-patológica comum, caracterizada por depósito de lipídeos no hepatócito do parênquima hepático. A esteatose hepática (EH) é um dos componentes da DHGNA e caracteriza-se pela presença de vacúolos de lipídeos, principalmente triacilgliceróis (triglicerídeos), dentro dos hepatócitos. Alterações na oxidação das gorduras no fígado ou redução na exportação de lipoproteínas de muito baixa densidade (VLDL) a partir do órgão são os principais mecanismos etiopatogênicos envolvidos com a EH. A patogênese da DHGNA é multifatorial e diversos fatores ou condições têm sido relacionados à predisposição para o seu desenvolvimento. Atualmente, diferentes tratamentos farmacológicos para DHGNA estão sendo propostos, mas ainda não há nenhum estudo comprobatório da sua eficácia. Objetiva-se avaliar os efeitos da suplementação da colina e do frutooligossacarídeo (FOS) na dieta de ratos Wistar, no modelo de esteatose hepática, induzido por dieta hiperglicídica. Foram utilizados 46 ratos machos, da raça Wistar adultos com peso variando entre 250 - 320 g, vindos do Biotério Central do Campus da USP Ribeirão Preto. Do lote inicial de animais foram distribuídos de forma aleatória nos diferentes grupos de estudo de I a IV, dependendo da indução ou não da esteatose. Considerou-se fase I o período correspondente a indução de esteatose e fase II quando se submeteu os animais a suplementação com nutrientes (Grupos III e IV), ou quando os animais receberam dieta padrão pós fase I (Grupo II) . Foi analisado as seguintes variáveis: Ingestão alimentar semanal, evolução do peso dos animais, nitrogênio urinário, amônia urinária, colesterol total e triacilgliceróis séricos, peso úmido de fígado e coração, nitrogênio e gordura tecidual, dosagem de vitamina $\mathrm{E}$, malondialdeído (MDA) e glutationa no tecido hepático e análise histopatológica. Observamos que nenhum dos nutrientes empregados (colina e FOS) foi eficaz na redução da quantidade de gordura do fígado pela análise histológica, e também não protegeram o fígado da ação dos radicais livres, já que o MDA, um marcador indireto da geração do estresse oxidativo, manteve-se com valores elevados mesmo na fase de tratamento. A colina foi o nutriente capaz de aumentar os níveis hepáticos de vitamina E e glutationa reduzida, quando suplementada pós indução de esteatose. Ocorreu diminuição dos níveis de triacilgliceróis em todos os grupos submetidos à indução de esteatose, do início ao final do experimento. O frutooligossacarídeo foi o único nutriente capaz de reduzir os níveis de colesterol sérico, em relação aos seus níveis basais, quando suplementado após indução de esteatose. 


\section{SÍNDROME PULMONAR E CARDIOVASCULAR POR HANTAVÍRUS: ESTUDOS SOBRE UMA DOENÇA EMERGENTE}

\section{Gelse Mazzoni Campos}

Orientador: Prof. Dr. Luiz Tadeu Moraes Figueiredo

Tese de Doutorado apresentada em 29/02/2008

A Síndrome Pulmonar e Cardiovascular por Hantavírus (SPCVH) é doença emergente nas Américas, causada pela aspiração de aerossóis dos dejetos de roedores silvestres da subfamília Sigmodontinae, contaminados por vírus do gênero Hantavirus, família Bunyaviridae. No Brasil, ocorre SPCVH desde 1993, com alta letalidade. Esta Tese teve múltiplos objetivos, incluindo: estudar a apresentação clínica da SPCVH, estudar a epidemiologia das infecções por Hantavirus, buscar por casos de Hantavirose com doença menos grave que a SPCVH e avaliar pela clínica e exames complementares, sobreviventes de SPCVH. Para tanto, utilizando um protocolo-padrão, pesquisamos prontuários hospitalares, realizamos exames médicos, análises bioquímicas, sorológicas e hormonais, oftalmoscopias, ecocardiogramas, espirometrias e tomografias computadorizadas de tórax em sobreviventes da SPCVH; pesquisamos anticorpos e vírus, por ELISAe RT-PCR, em casos febris de Jardinópolis e Cássia dos Coqueiros, SP, Brasil; analisamos alterações ambientais e exposições de risco aos Hantavirus. Assim, de uma casuística com 70 pacientes de SPCVH, casos ocorridos de 1998 a 2007, na região de Ribeirão Preto, SP, Brasil, observamos que: ocorreu maior incidência de abril a setembro (estiagem), $75,7 \%$ dos casos eram do sexo masculino, com 35,8 anos em média ( $\pm 11,7$ anos). Os pacientes, após incubação de 2 a 30 dias, tinham dispnéia (87\%), febre (81\%), tosse (44\%) e cefaléia (34\%), por 3 a 6 dias (média de 4), acompanhados de taquicardia (81\%), hipotensão arterial (56\%) e diminuição da saturação de hemoglobina por $\mathrm{O}_{2}(49 \%)$; acidose metabólica (57\%), linfocitopenia (51\%), hematócrito $>45 \mathrm{mg} \%$ (70\%), leucocitose com desvio à esquerda (67\%), creatinina $(51 \%)$ e uréia (42\%) séricas elevadas. Também, tinham alteração radiológica bilateral, difusa e intersticial entre o $1^{\circ}$ e o $4^{\circ}$ dia de doença e alveolar após o $4^{\circ}$ dia. A maior letalidade ocorreu no $4^{\circ}$ dia. O estudo clínico de 20 sobreviventes da SPCVH mostrou 8 com sintomas leves (40\%). Em ecocardiogramas, 8 casos (44\%) apresentaram alterações leves e em tomografias computadorizadas de tórax, $4(21 \%)$, também, mostraram alterações leves. Ainda 5 (28\%) espirometrias mostraram doença leve. À oftalmoscopia, 6 indivíduos tinham coriorretinite e 1 meibonite. Pudemos observar que a evolução da SPCVH para insuficiência respiratória, hipotensão arterial e choque ocorre 24-48 horas após a fase inicial; o hematócrito elevado e a plaquetopenia são sinais fortemente sugestivos da doença; a hipótese diagnóstica de Pneumonia Atípica foi associada a bom prognóstico ( $p: 0,0136$ ); a infusão hídrica $>2.000 \mathrm{ml}$ e hipotensão arterial foram associadas a mau prognóstico ( $p: 0,0286$ e p:0,0453); contato com roedores infectados mostrou-se fator de risco para transmissão e morbidade (p:0,0198). A SPCVH é doença com alta letalidade (54,3\%).

\section{EFEITOS DA SUPLEMENTAÇÃO COM CREATINA SOBRE OS NÍVEIS DE HOMOCISTEÍNA E PEROXIDAÇÃO LÍPIDICA EM RATOS}

\section{Rafael Deminice}

Orientador: Prof. Dr. Alceu Afonso Jordão Júnior

Dissertação de Mestrado apresentada em 28/3/2008

Nos últimos anos, a hiperhomocisteinemia (HHcy) tem sido apontada como fator de risco independente para diversas doenças entre elas cardiovasculares, renais e demências possivelmente por estar diretamente ligada à formação de espécies reativas de oxigênio. A síntese de creatina $(\mathrm{Cr})$ é responsável pela maioria das transferências de grupos metila no metabolismo hepático normal. Como a homocisteína (Hcy) é um aminoácido formado exclusivamente a partir da desmetilação da metionina, acredita-se que a inibição da síntese de $\mathrm{Cr}$, através da suplementação desse composto, pode modular o fluxo de metilação e diminuir a concentração de Hcy. O objetivo principal do presente estudo foi investigar os efeitos da suplementação de
Cr sobre o balanço de metilação, concentração de Hcy e peroxidação lipídica de ratos saudáveis. Quarenta e dois ratos foram divididos em 4 grupos: grupo controle (C); grupo sobrecarga de creatina $(\mathrm{SCr}=5 \mathrm{mg} / \mathrm{kg}$ creatina monohidratada por gavagem $/ 5$ dias); grupo creatina na dieta $(\mathrm{CrD}$ $=2 \%$ creatina monohidratada na dieta/28 dias) e grupo creatina na dieta mais sobrecarga $(\mathrm{CrD}+\mathrm{S}=5 \mathrm{mg} / \mathrm{kg}$ creatina monohidratada gavagem $/ 5$ dias $+2 \%$ na dieta $/ 22$ dias). Após 28 dias os animais foram sacrificados. O fígado, músculo sóleo, plasma e urina de $24 \mathrm{~h}$ foram coletados. Foram determinados os biomarcadores Hcy, vitaminas B12 e folato (Fol), creatina, TBARs como biomarcador de peroxidação lipídica, glutationa reduzida (GSH) como marcador do sistema de defesa antioxidante e aminoácidos no plasma; Cr e creatinina urinárias (Crn); e Cr e fosfocreatina intramuscular para determinação de creatina muscular total (tCr). A suplementação de $\mathrm{Cr}$ aumentou significativamente a con- 


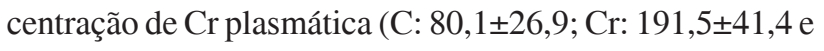
$\mathrm{SCr}+\mathrm{D}: 204,8 \pm 29,8, \mu \mathrm{mol} / \mathrm{L})$ e tCr intramuscular (C: 17,8 $\pm 1,1$; Cr: 19,1 $\pm 3,4$ e SCr+D: $21 \pm 1,8, \mu \mathrm{mol} / \mathrm{g}$ TU) nos animais dos grupos $\mathrm{Cr}$ e $\mathrm{SCr}+\mathrm{D}$ com relação ao $\mathrm{C}$. A Hcy plasmática foi significativamente menor nesses grupos $\mathrm{Cr}(7,5 \pm 1,2 \mu \mathrm{mol} /$ $\mathrm{L})$ e $\mathrm{SCr}+\mathrm{D}(7,3 \pm 1,7 \mu \mathrm{mol} / \mathrm{L})$ em relação ao C (12,4 $\pm 2,2 \mu \mathrm{mol} /$ L). O mesmo foi encontrado em relação ao TBARs $(\mathrm{C}=$ $10 \pm 3,4 ; \mathrm{SCr}=5,4 \pm 1,3 ; \mathrm{Cr}=4,9 \pm 0,7 \mathrm{e} \mathrm{SCr}+\mathrm{D}=2,4 \pm 1, \mu \mathrm{mol} / \mathrm{L})$.
Além disso, correlações $(\mathrm{p}<0,05)$ foram encontradas da Hcy com $\mathrm{Cr}(\mathrm{r}=-0,58), \mathrm{tCr}(\mathrm{r}=-0,39)$ e TBARs $(\mathrm{r}=0,60)$; e da TBARs com $\mathrm{Cr}(\mathrm{r}=-0,63)$ e $\mathrm{tCr}(\mathrm{r}=-0,45)$. Pode-se concluir que a suplementação de $2 \%$ na dieta de $\mathrm{Cr}$ aumenta a concentração plasmática e intramuscular de Cr. Tal aumento é capaz de diminuir os níveis plasmáticos de Hcy através da modulação do balanço de metilação, além de exercer papel protetor contra peroxidação lipídica.

\section{FARMACOLOGIA}

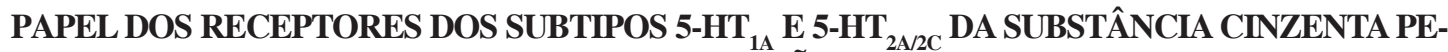 RIAQUEDUTAL VENTROLATERAL NA MODULAÇÃO DE COMPORTAMENTOS DEFENSIVOS ASSOCIADOS À ANSIEDADE}

\section{Vanessa de Paula Soares}

Orientador: Prof. Dr. Hélio Zangrossi Júnior

Tese de Doutorado apresentada em 18/01/2008

A coluna ventrolateral da substância cinzenta periaquedutal (SCPvl) tem sido consistentemente implicada na mediação de comportamentos defensivos. Neste trabalho, procuramos avaliar se receptores serotonérgicos dos tipos $5-\mathrm{HT}_{1 \mathrm{~A}}$ e 5-HT $\mathrm{H}_{2 \mathrm{~A} / 2 \mathrm{C}}$ presentes nesta região modulam, de maneira distinta, respostas defensivas que têm sido relacionadas à ansiedade (ex. esquiva inibitória) e ao medo (ex. fuga). Em termos de fisiopatologia, estes comportamentos têm sido associados, respectivamente, ao transtorno de ansiedade generalizada e ao transtorno de pânico. Para tal análise, empregamos o teste do labirinto em T elevado (LTE), que permite avaliar respostas de esquiva inibitória e de fuga em um mesmo animal. Ratos Wistar machos receberam intra-SCPvl o agonista endógeno serotonina, o agonista de receptores do tipo 5- $\mathrm{HT}_{1 \mathrm{~A}}$ 8-OH-DPAT e o agonista de receptores dos tipos 5-HT $2 \mathrm{~A} / 2 \mathrm{C}$ DOI. Os efeitos destes agonistas foram comparados aos causados pela microinjeção do ansiolítico benzodiazepínico midazolam. Posteriormente, foram realizados estudos de antagonismo, a fim de melhor caracterizar a contribuição dos receptores dos tipos $5-\mathrm{HT}_{1 \mathrm{~A}}$ e $5-\mathrm{HT}_{2 \mathrm{~A}}$ nos efeitos promovidos pelos agonistas.

Nossos dados mostram que, quando ativados, os receptores serotonérgicos dos tipos $5-\mathrm{HT}_{1 \mathrm{~A}}$ e $5-\mathrm{HT}_{2 \mathrm{~A}}$ da SCPvl modulam preferencialmente comportamentos relacionados à ansiedade. Isto é evidenciado pelo fato de que a microinjeção do 8-OH-DPAT, do DOI e da serotonina inibiu seletivamente a aquisição da resposta de esquiva inibitória dos animais, indicando um efeito do tipo ansiolítico. Resul- tado semelhante foi obtido após a microinjeção de midazolam. Nossos resultados mostram ainda que a administração intra-SCPvl de WAY-100635 e quetanserina, respectivamente antagonista de receptores do tipo 5- $\mathrm{HT}_{1 \mathrm{~A}}$ e antagonista de receptores do tipo 5- $\mathrm{HT}_{2 \mathrm{~A}}$, em doses capazes de antagonizar o efeito dos agonistas serotonérgicos, não alterou o comportamento dos animais no LTE. Isto sugere que a expressão das respostas de esquiva e de fuga geradas no LTE não parece envolver a ativação de receptores dos tipos 5-HT ${ }_{1 \mathrm{~A}}$ e $5-\mathrm{HT}_{2 \mathrm{~A}}$ da SCPvl pela serotonina.

De maneira interessante, doses maiores de WAY$100635(0,185$; 0,37 e 0,74 nmol), que não promoveram alteração comportamental quando administradas na substância cinzenta periaquedutal dorsal em estudos anteriores, promoveram, no presente estudo, inibição da resposta de esquiva inibitória. Este efeito do tipo ansiolítico, observado tanto após a administração de WAY-100635, quanto de 8-OH-DPAT, foi também detectado em outro modelo animal associado à ansiedade generalizada, o teste de transição claro-escuro. Com base em nossos resultados, sugerimos que o efeito promovido pelo WAY-100635 se deva a ação deste antagonista sobre outros sistemas de neurotransmissão, que não o serotonérgico. Já o efeito do 8-OH-DPAT é mediado por receptores do tipo $5-\mathrm{HT}_{1 \mathrm{~A}}$. Ainda que este agonista, em doses elevadas, possa atuar como agonista de receptores do tipo 5- $\mathrm{HT}_{7}$, no presente estudo, o 8-OHDPAT teve seu efeito bloqueado por uma dose ineficaz de WAY-100635, mas não do antagonista de receptores do tipo 5- $\mathrm{HT}_{7}$ SB269970.

Em conclusão, a ativação de receptores dos tipos $5-\mathrm{HT}_{1 \mathrm{~A}}$ e 5-HT $2 \mathrm{~A}$ da SCPvl altera respostas defensivas relacionadas à ansiedade, mas não ao medo. 


\section{ALTERAÇÕES DAS CONCENTRAÇÕES PLASMÁTICAS DE TROPONINA I E DE METALOPRO- TEINASES 2 E 9 DA MATRIZ EXTRACELULAR APÓS EMBOLIA AGUDA EM CÃES}

\author{
Juliana Alves Uzuelli \\ Orientador: Prof. Dr. José Eduardo Tanus dos Santos \\ Dissertação de Mestrado apresentada em 07/02/2008
}

O diagnóstico da tromboembolia pulmonar aguda (EPA) e a avaliação da gravidade desta condição é desafiador. Enquanto as concentrações de troponina I cardíaca (TI) já estão bem estabelecidas quanto ao risco de estratificação, não há estudos prévios que tenham examinado se há alguma relação linear entre as concentrações de TI cardíaca e a gravidade da EPA. Além disso, as metaloproteinases (MMPs) da matriz extracelular estão envolvidas na fisiopatologia da EPA. Entretanto, é desconhecido se o aumento da atividade gelatinolítica das MMPs após a EPA reflete a gravidade desta condição. Nós examinamos se as concentrações circulantes destes biomarcadores aumentam em proporção à gravidade da EPA experimental induzida em cães anestesiados. A EPA foi induzida com coágulos de sangue autólogo (salina, 1, 3 ou $5 \mathrm{~mL} / \mathrm{Kg}$ ) injetados no átrio direito. As avaliações hemodinâmicas foram realizadas no momento basal e 120 minutos após a EPA. Da mesma forma, foram realizadas as quantificações de troponina I no soro e a zimografia das MMPs 2 e 9 no plasma. Nossos resultados sugerem não haver aumento significativo da atividade gelatinolítica da pró-MMP-2 no plasma após a EPA, enquanto que a atividade da pró-MMP-9 aumenta em $80 \%$ apenas no grupo que recebeu $5 \mathrm{~mL} / \mathrm{Kg}$ de coágulos. A TI cardíaca no soro e a atividade da pró-MMP-9 no plasma tiveram uma correlação positiva com o índice de resistência vascular pulmonar ( $\mathrm{p}=0,007$ e rs $=0,833$ para a TI, e $\mathrm{p}=0,034$ e rs=0,684 para a pró-MMP-9) e com a pressão média na artéria pulmonar ( $\mathrm{p}=0,005$ e rs $=0,610$ para a TI, e $\mathrm{p}=0,022 \mathrm{e}$ rs=0,720 para a pró-MMP-9). Concluímos que a TI cardíaca e a pró-MMP-9 circulantes aumentam em proporção à gravidade da EPA, embora o aumento da pró-MMP-9 não seja muito evidente em graus menos severos da EPA. Estes achados podem ser relevantes para a clínica da EPA.

\section{PARTICIPAÇÃO DE RECEPTORES CB1 DA SUBSTÂNCIA CINZENTA PERIAQUEDUTAL DOR- SOLATERAL DE RATOS NA MODULAÇÃO DE RESPOSTAS DEFENSIVAS}

\section{Sabrina Francesca de Souza Lisboa \\ Orientador: Prof. Dr. Francisco Silveira Guimarães \\ Dissertação de Mestrado apresentada em 22/02/2008}

A substância cinzenta periaquedutal dorsolateral (SCPdl) é uma estrutura mesencefálica que circunda o aqueduto cerebral e está envolvida na modulação de comportamentos como dor e analgesia, medo e ansiedade, além de participar no controle cardiovascular. A ativação de receptores CB1 nesse local pela administração de anandamida (AEA) produziu efeitos ansiolíticos em ratos submetidos ao labirinto em cruz elevado. O objetivo deste trabalho foi o de verificar se a administração de AEA na SCPdl também poderia produzir efeitos ansiolíticos em dois outros modelos animais, o teste de conflito de Vogel e o medo condicionado ao contexto. Também verificamos se estes efeitos seriam reproduzidos pela facilitação local da neurotransmissão mediada por endocanabinóides e se eles seriam mediados por ativação de receptores CB1. Ratos Wistar machos $(\mathrm{n}=5-7)$ com cânulas direcionadas à SCPdl receberam uma primeira microinjeção de veículo ou AM251 (antagonista de receptores $\mathrm{CB} 1,100 \mathrm{pmol} / 0,2 \mu \mathrm{L}$ ) seguida, 5 min após, por uma segunda microinjeção de veículo, AEA (5 pmol/ 0,2 $\mu \mathrm{L})$ ou AM404 (inibidor de metabolismo e recaptação da AEA, $50 \mathrm{pmol} / 0,2 \mu \mathrm{L}$ ). No modelo de medo condicionado ao contexto foram avaliadas as respostas comportamentais (congelamento) e cardiovascular (pressão arterial média e frequência cardíaca) de animais re-expostos a um contexto no qual haviam recebido $48 \mathrm{~h}$ antes choques elétricos nas patas. No teste de Vogel os animais foram privados de água por $24 \mathrm{~h}$ e pré-expostos ao aparato onde poderiam beber livremente por $3 \mathrm{~min}$. Após $24 \mathrm{~h}$ adicionais de privação, eles receberam os tratamentos farmacológicos e após $10 \mathrm{~min}$ foram colocados na caixa de experimentação. Nessa caixa eles recebiam um choque elétrico na língua através do bico do bebedouro a cada 20 lambidas. No teste de Vogel, a AEA e o AM404 aumentaram o número total de lambidas punidas. Este efeito foi bloqueado pelo antagonista de receptores CB1, AM251. No condicionamento aversivo ao contexto, a AEA e o AM404 reduziram o tempo de congelamento e as respostas cardiovasculares causadas pela exposição ao contexto aversivo. Estes efeitos também foram bloqueados por AM251. Essa droga, por si só, não produziu nenhum efeito nos dois modelos. Estes resultados sugerem que o sistema canabinóide endógeno localizado na SCPdl participa da modulação de reações defensivas. 


\section{EFEITO DO CANABIDIOL INJETADO NA SUBSTÂNCIA CINZENTA PERIAQUEDUTAL DORSO- LATERAL DE RATOS SUBMETIDOS A DOIS MODELOS DE ANSIEDADE}

\begin{abstract}
Alline Cristina de Campos
Orientador: Prof. Dr. Francisco Silveira Guimarães

Dissertação de Mestrado apresentada em 26/02/2008

O canabidiol (CBD) é um componente nãopsicotomimético da Cannabis sativa. Estudos em animais de laboratório e humanos sugerem que a administração sistêmica deste composto produz efeitos ansiolíticos. Os mecanismos e locais de ação destes efeitos, no entanto, ainda não foram investigados. Considerando que a substância cinzenta periaquedutal dorsolateral (SCPdl) tem sido relacionada com a ansiedade e possui receptores para endocanabinóides. O presente projeto objetivou investigar o efeito da microinjeção de CBD (30-120 nmol) na SCPdl de ratos submetidos a dois modelos de ansiedade, o labirinto em cruz elevado (LCE) e o teste do lamber punido de Vogel. O CBD na dose de 30nmol injetado na SCPdl produziu efeito ansiolítico no labirinto em Cruz elevado com curva doseresposta em forma de U-invertido. O efeito ansiolítico do
\end{abstract}

CBD foi confirmado no modelo de Lamber Punido de Vogel. Entre os possíveis mecanismos propostos para o CBD, foi sugerida a inibição da hidrólise e/ou da recaptação da anandamida, um endocanabinóide, ou o efeito agonista em receptores 5-HT1A ou TPRPV1. Ao testarmos estas possibilidades verificamos que os efeitos do CBD na SCPdl parecem não ser mediados por receptores $\mathrm{CB} 1$, já que não foram antagonizados pelo AM251, um antagonista de receptores CB1. No entanto o WAY100635, um antagonista de receptores 5HT1A, bloqueou o efeito ansiolítico do CBD. Além disso, a Capsazepina, um antagonista de receptores vanilóides, não foi capaz de reverter o efeito ansiolítico do CBD na dose de $30 \mathrm{nmol}$, mas transformou a maior dose não efetiva testada (60nmol) em uma dose ansiolítica. Os resultados sugerem que o CBD produz efeitos ansiolíticos quando injetado na SCPdl por ativar receptores 5HT1A. Além disso, em altas concentrações poderia também ativar receptores vanilóides, o que produziria efeitos opostos aos observados com concentrações mais baixas da droga.

\section{ATIVIDADE E EXPRESSÃO DA ELASTASE-2, ENZIMA FORMADORA DE ANGIOTENSINA II, EM RATOS NORMOTENSOS E ESPONTANEAMENTE HIPERTENSOS TRATADOS COM ENALAPRIL}

\section{Christiane Becari}

Orientadora: Profa. Dra. Maria Cristina de Oliveira Salgado Tese de Doutorado apresentada em 03/03/2008

Vários trabalhos têm demonstrado a participação de vias alternativas à enzima conversora de angiotensina (ECA) na geração de angiotensina (Ang) II, tais como quimase de coração humano e elastase-2 de rato. O objetivo deste estudo foi investigar a participação da(s) via(s) formadora(s) de Ang II em carótida isolada de ratos normotensos (wistar) e com hipertensão espontânea (SHR) tratados com inibidor da ECA (enalapril), verificando em particular a participação da elastase-2. Os animais normotensos e SHR receberam tratamento com enalapril por $7 \mathrm{dias}(10 \mathrm{mg} / \mathrm{kg} / \mathrm{dia}$, via oral por gavagem). A atividade da ECA tecidual (carótida e aorta) em ratos hipertensos foi menor que em normotensos e o tratamento com enalapril foi eficaz em inibir a atividade da ECA no plasma e no tecido vascular, além disso, induziu significativa diminuição dos níveis pressóricos nos SHR. Foram realizadas curvas cumulativa concentração-resposta para Ang II e Ang I em anéis de carótidas de ratos normotensos e hipertensos controles e tratados cronicamente com enalapril na ausência e presença dos diferentes inibidores. Em carótidas de animais normotensos e hipertensos tratados com enalapril, as curvas concentração-resposta para Ang I apresentaram-se deslocadas à direita, enquanto que as curvas para Ang II não foram alteradas. Na presença de losartan, antagonista dos receptores AT1, a resposta contrátil induzida pelos peptídeos Ang II e I foram completamente abolidas. Considerando que o enalapril poderia ter se dissociado da ECA, in vitro, um outro inibidor da ECA, captopril, foi adicionado à cuba para inibir totalmente a ECA. Nestas condições, a resposta a Ang II não foi alterada, no entanto as curvas concentração-efeito a Ang I apresentaram deslocamento significativo à direita em ratos normotensos e em ratos hipertensos embora esse deslocamento tenha sido de menor magnitude nas preparações de SHR em relação a de ratos normotensos. Na presença de quimostatina, inibidor seletivo de serino proteases como a elastase-2, ocorreu um deslocamento à direita da curva concentraçãoresposta à Ang I tanto em animais controles como nos tratados com enalapril $(\mathrm{p}<0,001)$, sendo o deslocamento mais proeminente nos animais hipertensos tratados $(\mathrm{p}<0,0001)$. Para verificarmos se o tratamento crônico com enalapril favoreceu uma maior contribuição da elastase- 2 avaliamos a expressão do RNAm para elastase-2 por reação em cadeia de polimerase em tempo real (PCR em tempo real). A expressão da elastase-2 encontrava-se aumentada no coração e carótida de ratos hipertensos tratados com enalapril. Em conjunto, estes dados indicam a participação de vias sensíveis a quimostatina, como a elastase-2, na conversão de Ang I em Ang II e que sua atividade e/ou expressão está aumentada em carótida de ratos normotensos e de forma mais proeminente em SHR na vigência da inibição da ECA. 


\section{FISIOLOGIA}

\section{DESENVOLVIMENTO DE MÉTODO PARA O ESTUDO DA MOTILIDADE GASTRINTESTINAL NO CÃO EMPREGANDO A BIOSUSCEPTOMETRIA DE CORRENTE ALTERNADA (BAC)}

\author{
Madileine Francely Américo \\ Orientador: Prof. Dr. Ricardo Brandt de Oliveira \\ Tese de Doutorado apresentada em 08/02/2008
}

A motilidade colônica é pouco compreendida quando comparada a do TGI (trato gastrintestinal) superior. A utilização de metodologias, sem radiação ionizante e de baixo custo em modelos animais, pode contribuir para o entendimento da atividade colônica. O objetivo desse trabalho foi validar a BAC (Biosusceptometria AC), por meio da EMG (Eletromiografia), em um modelo em cães para avaliar a motilidade do TGI. Conjuntos eletrodo/marcador magnético foram implantados na serosa colônica e gástrica de sete cães saudáveis. Três protocolos foram utilizados: a) con-

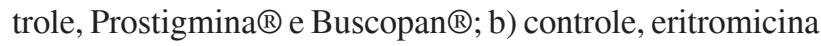
(EM) em três doses $(0,4 ; 2,0$ e $10 \mathrm{mg} / \mathrm{Kg})$ e pós-droga; c) jejum e alimentado sem anestesia. A atividade colônica nas faixas de baixa e de alta frequiência e a faixa típica do estômago foram quantificadas em freqüência e amplitude. Ape- nas a EMG registrou alta freqüência, no entanto, a BAC e a EMG tiveram alta correlação em baixa frequiência. O protocolo empregando Prostigmina ${ }^{\circledR}$ e Buscopan ${ }^{\circledR}$ demonstrou que a BAC é capaz de registrar o aumento e a diminuição da motilidade, respectivamente. O efeito pró-cinético da eritromicina sobre o estômago e sobre o cólon é dependente da dose administrada. O aumento da dose de EM diminuiu o intervalo entre administração e resposta máxima, ao contrário do que ocorreu com a duração da resposta. Na faixa de alta frequiência, tanto a Prostigmina ${ }^{\circledR}$ quanto a dose de $10 \mathrm{mg} / \mathrm{kg}$ da EM provocaram diminuição da atividade. A resposta colônica à refeição foi registrada em cães não anestesiados. Houve interferência elétrica e mecânica do estômago sobre o cólon e vice-versa com alta correlação temporal. A correlação entre EMG e BAC permitiu caracterizar os efeitos colônicos de drogas tradicionais, pró-cinéticos e refeições. A BAC é uma técnica capaz de registrar as contrações, contribuindo para o entendimento da motilidade do TGI, inclusive a colônica.

\section{ENVOLVIMENTO DA FORMAÇÃO HIPOCAMPAL DORSAL NA MODULAÇÃO DA IMOBILIDA- DE TÔNICA E NA NOCICEPÇÃ̃O EM COBAIAS (Cavia porcellus) E A INTERAÇÃO FUNCIONAL COM A ÁREA SEPTAL MEDIAL}

\section{Lys Angela Favaroni Mendes}

Orientadora: Profa. Dra. Leda Menescal de Oliveira

Tese de Doutorado apresentada em 03/03/2008

A imobilidade tônica (IT) é uma resposta comportamental defensiva inata, na qual ocorre perda do reflexo de endireitamento, depressão dos reflexos polissinápticos extensores e flexores e relativa redução na reatividade a estímulos ambientais. Estudos prévios do laboratório mostraram que a formação hipocampal dorsal (FHD) e o sistema colinérgico estão envolvidos na modulação da IT em cobaias. A estimulação colinérgica da FHD diminui a duração dos episódios de IT e este efeito, provavelmente, é mediado por receptores muscarínicos. Numerosas evidências fisiológicas, farmacológicas e comportamentais sugerem o envolvimento da FHD em respostas nociceptivas. Além disso, acredita-se que parte das funções desempenhadas pela FHD ocorre por meio de aferentes provenientes da área septal medial (ASM). Dessa maneira, os objetivos do presente estudo foram: 1) investigar a possibilidade da FHD de cobaias modular a duração dos episódios de IT e a res- posta nociceptiva, por meio da interação de mecanismos colinérgicos, opioidérgicos e GABAérgicos e 2) investigar a participação de uma possível conexão funcional entre FHD e ASM na regulação da resposta comportamental de IT. Os resultados mostram que a microinjeção de morfina diminuiu a duração do comportamento defensivo de IT e o índice de vocalização que indica antinocicepção, efeitos esses bloqueados pela administração prévia de naloxone, um antagonista preferencial $\mu$-opióide. A administração de bicuculina no mesmo sítio produziu diminuição da duração dos episódios de IT e antinocicepção. Ao contrário, o tratamento com o muscimol na FHD promoveu hiperalgesia e um aumento na duração da resposta comportamental de IT. A microinjeção do agonista colinérgico carbacol na FHD promoveu uma redução na nocicepção, medida pelo teste de vocalização em cobaias e esse efeito foi bloqueado pela microinjeção prévia da atropina, indicando a participação de receptores muscarínicos na modulação dessa resposta. Além disso, o efeito da administração do carbacol e da morfina na FHD foi revertido pelo pré-tratamento com naloxone microinjetado no mesmo local, sugerindo uma in- 
teração colinérgica-opioidérgica nesse substrato neural modulando o comportamento defensivo de IT e antinocicepção. A microinjeção de muscimol, por sua vez, preveniu o efeito antinociceptivo e a redução da IT provocada pela morfina. Juntos, esses resultados sugerem que a transmissão colinérgica pode ativar a liberação de endorfinas/ encefalinas de interneurônios da FHD, que, por sua vez inibiria neurônios GABAérgicos, resultando assim em antinocicepção e no término do comportamento de IT. Nossos resultados nos permitem sugerir, portanto, que na FHD os mesmos sistemas neurotransmissores, colinérgico, opioidérgico e GABAérgico podem modular os sistemas defen- sivo e antinociceptivo de maneira independente. Dessa maneira, a ativação hipocampal produz diminuição da duração da IT e antinocicepção, como promovido pelas microinjeções de carbacol, morfina e bicuculina nesse sítio. Por outro lado, a inativação da FHD produz aumento da duração da IT e hiperalgesia como visto pela microinjeção de muscimol nesse local. Em relação a conexão ASM-FHD, nossos resultados mostraram que a participação da ASM na modulação da IT parece depender de sua eferência colinérgica para a FHD, enquanto que o contrário não é verdadeiro. Isso sugere que a FHD pode modular a IT possivelmente via conexões com outras estruturas encefálicas.

\section{ALTERAÇÕES HEMODINÂMICAS E NEURO-HUMORAIS NA HIPERTENSÃO UM RIM, UM CLI- PE (1R1C) DO CAMUNDONGO}

\section{Giulianna da Rocha Borges}

Orientador: Prof. Dr. Hélio César Salgado

Tese de Doutorado apresentada em 17/03/2008

O balanço simpato-vagal e o controle barorreflexo da freqüência cardíaca (FC) foram avaliados durante o desenvolvimento (1 e 4 semanas) da hipertensão um rim, um clipe (1R1C) em camundongos não-anestesiados. O desenvolvimento de hipertrofia cardíaca e fibrose também foi examinado. A variabilidade da pressão arterial (PA) sistólica e da FC no domínio do tempo (desvio padrão) e a sensibilidade do barorreflexo foram calculados a partir dos registros basais. Metil-atropina e propranolol permitiram a avaliação do balanço simpato-vagal e da frequiência intrínseca de marcapasso (FIMP). A marcação de angiotensina II renal e a atividade da renina plasmática (ARP) também foram avaliadas. Uma e 4 semanas após o clampeamento da artéria renal, os camundongos estavam hipertensos e taquicárdicos e exibiram tono simpático elevado e tono vagal reduzido. A FIMP estava elevada apenas nos camundongos 1R1C de 1 semana. A variabilidade da PA sistólica estava elevada, enquanto a variabilidade da FC e a sensibilidade do barorreflexo estavam reduzidas nos hipertensos de 1 e 4 semanas. A marcação da angiotensina II renal e a ARP estavam elevadas apenas 1 semana após o clampeamento. Hipertrofia cardíaca concêntrica foi observada nos hipertensos de 1 e 4 semanas, enquanto que fibrose cardíaca foi observada apenas após 4 semanas de hipertensão. Concluindo, o desenvolvimento da hipertensão 1R1C em camundongos revelou taquicardia, tono simpático aumentado e tono vagal reduzido para o coração. Além disso, redução da sensibilidade do barorreflexo cardíaco, aumento da variabilidade da PA sistólica, diminuição da variabilidade da FC, hipertrofia concêntrica e fibrose também foram observados. Aumento da FIMP e hiperatividade do sistema renina-angiotensina foram observados apenas nos camundongos hipertensos de 1 semana.

\section{GENÉTICA}

\section{GENES CODIFICADORES DOS PEPTÍDEOS ANTIMICROBIANOS E DE OUTRAS PROTEÍNAS ENVOLVIDAS NA RESPOSTA IMUNE DE Apis mellifera}

\section{Anete Pedro Lourenço \\ Orientadora: Profa. Dra. Zilá Luz Paulino Simões \\ Tese de Doutorado apresentada em 11/01/2008}

Os insetos desenvolveram um sistema imune eficiente contra parasitas e patógenos, que compreende a resposta celular e a humoral. Os mecanismos celulares envol- vem a fagocitose e a encapsulação pelos hemócitos, enquanto que as respostas humorais incluem a ativação da Profenoloxidase, e a síntese pelo corpo gorduroso dos peptídeos antimicrobianos, que são liberados na hemolinfa. Duas vias de sinalização intracelular, Toll e Imd, controlam a expressão dos genes codificadores dos peptídeos antimicrobianos. A análise do Genoma da abelha Apis mellifera per- 
mitiu a identificação dos genes dessas vias. No entanto, pouco se conhece do mecanismo de resposta imune nessas abelhas. Desta maneira, nos propusemos analisar a transcrição de genes efetores da resposta imune (abaecina, hymenoptaecina, defensina, transferrina, profenoloxidase), assim como os genes integrantes das vias de sinalização, tais como os genes de reconhecimento de microorganismos $(P G R P, G N B P)$ e ainda, os de sinalização (cactus, relish, dorsal 1-B). Avaliamos também possíveis proteínas implicadas na resposta imune, como as proteínas de estocagem Vitelogenina, Hexamerina 70a, Lipoforina I/II e Lipoforina III. Finalmente, analisamos o efeito da nutrição e do envelhecimento sobre a imunidade em abelhas. Para análise da expressão dos genes das vias de sinalização, as abelhas foram infectadas com bactérias Serratia marcescens ou Micrococcus luteus por injeção ou via alimentação. A infecção com esses microorganismos provocou a transcrição de peptídeos antimicrobianos e de transferrina em altas quantidades após 3 e 12 horas de tratamento, além da alteração na quantidade de transcritos de outros genes. O papel dos genes profenoloxidase e dorsal na imunidade, descritos como codificadores de importantes proteínas em outros insetos, foi avaliado através da metodologia de silenciamento gênico por RNA de interferência. Observamos a diminuição da transcrição do gene alvo, mostrando a eficiência da metodologia. No entanto, a simples injeção de um RNA de fita dupla foi capaz de ativar o sistema imune de abelhas. Este efeito contribuiu para a dificuldade de atribuição do papel da Profenoloxidase na imunidade de abelhas. Contudo, os resultados de silenciamento de dorsal e suas isoformas, nos levaram a considerar que dorsal 1-A ou dorsal 2 participam da via de sinalização intracelular para produção de peptídeos antimicrobianos, principalmente de defensina. Em relação às proteínas de estocagem, tanto a quantidade de transcritos quanto de proteínas diminui após infecção com bactérias, indicando que estas proteínas estão envolvidas de alguma forma no processo de imunidade em abelhas. Além disso, consumo de alimentos ricos em proteína aumentou os níveis de transcritosdas proteínas de estocagem, o que muito provavelmente favorece a manutenção da capacidade de resposta imune de abelhas. O efeito do envelhecimento no declínio da imunidade foi analisado em abelhas nutridoras (novas) e forrageiras (velhas) de uma colônia típica. Além disso, foram utilizadas abelhas de uma colônia single-cohort, que eram de uma mesma idade, mas algumas eram nutridoras, enquanto outras eram forrageiras. Todas as abelhas, independentemente da idade ou comportamento, foram capazes de ativar o sistema imune após infecção pela bactéria $S$. marcescens. No entanto, as abelhas com o comportamento de forrageira, independentemente da idade, sempre foram mais susceptíveis a infecções que as nutridoras. Este fato se deve, muito provavelmente, às diferenças fisiológicas entre essas abelhas, que proporciona às nutridoras maior competência à sobrevivência.

\section{POLIMORFISMO NOS GENES CYP17, CYP1B1, CYP1A1 E COMT E AS LESÕES GENÔMICAS ESPONTÂNEAS EM PACIENTES COM CÂNCER DE MAMA}

\section{Raquel Alves dos Santos}

Orientadora: Profa. Dra. Catarina Satie Takahashi

Tese de Doutorado apresentada em 22/02/2008

O Câncer de Mama (CM) é o segundo tipo mais freqüente de câncer no mundo e a doença maligna mais comum entre as mulheres. Apesar do câncer ser considerado uma típica doença do envelhecimento, o CM apresenta algumas características distintas no que diz respeito às taxas de incidência. Os fatores de risco para o CM incluem idade da menarca precoce e menopausa tardia, terapias hormonais, exposição aos poluentes ambientais, tabagismo e etilismo, no entanto, a exposição prolongada aos estrógenos representa o fator de risco mais importante. A biossíntese e a metabolização dos estrógenos requerem um grande número de vias que são reguladas por uma série de genes cujos polimorfismos têm sido descritos em associação com o CM. Também se sabe que os estrógenos podem danificar a molécula de DNA por aumentar a formação de aductos ou ainda por induzir a 8-hidroxilação de purinas e as quebras de fita simples e duplas do DNA. Dessa forma, o objetivo do pre- sente do presente trabalho foi investigar os níveis de danos no DNA de pacientes com CM antes da quimioterapia ou da radioterapia, a possível associação entre os polimorfismos dos genes metabolizadores de estrógeno CYP17, CYP1B1, CYPlA1 and COMT e o risco ao CM e também a possível influência desses polimorfismos nos níveis espontâneos de danos no DNA. Os linfócitos do sangue periférico de 45 mulheres com diagnóstico para Carcinoma Ductal in situ ou invasorl e 85 mulheres sadias (controles) foram utilizados para avaliação de danos espontâneos no DNA pelo teste do micronúcleo e Ensaio Cometa. Os resultados mostraram que as frequiências de micronúcleos (MNs) e os danos no DNA detectados pelo Ensaio Cometa foram significativamente maiores no grupo de pacientes do $\mathrm{CM}$ do que no grupo controle. Os níveis de danos no DNA foram similares entre fumantes e não-fumantes e a idade não influenciou as freqüências de MNs observadas em pacientes com CM e controles. Para a abordagem molecular a casuística foi de 131 mulheres controles saudáveis e 104 mulheres também com diagnóstico para Carcinoma ductal in situ ou invasor. A comparação da ocorrência dos polimorfismos estudados nos 
genes CYP17, CYP1Al e COMT não mostrou diferenças estatisticamente significativas entre pacientes e controles. Contudo, o genótipo Leu/Leu para o gene $C Y P 1 B 1$ aumentou em três vezes o risco para o CM entre não-fumantes $(\mathrm{P}=$ $0,04, \mathrm{OR}=3 ; 95 \%$ intervalo de confiança: $1,1-8,2)$. Os polimorfismos estudados nos genes citados acima não tiveram associação com a idade da menarca ou da menopausa em pacientes com CM e controles. A possível associação dos polimorfismos nos genes $C Y P 17, C Y P 1 B 1, C Y P 1 A 1 \mathrm{e}$ COMT sobre os níveis de danos no DNA também foi avaliada e, enquanto o $C Y P 17$ e $C Y P 1 A 1$ não afetaram as frequiências de MNs ou os danos no DNA observados pelo Ensaio Cometa nem em pacientes com CM nem no grupo controle, o alelo Leu do CYP1B1 esteve significativamente associado com altos níveis de danos no DNA do grupo controle, mas não interferiu nos danos do DNA detectados no grupo com CM. Em contrapartida, no grupo controle, o indivíduos portadores do alelo Met do gene COMT exibiram níveis mais baixos de danos no DNA quando comparados com o homozigoto selvagem, mas no grupo com CM os indivíduos polimórficos homozigotos (Met/Met) apresentaram níveis de danos no DNA mais elevados do que os seu correspondentes homozigotos selvagens e heterozigotos. Concluindo, este trabalho demonstrou que mulheres com CM apresentam uma instabilidade genômica importante e sugere que os polimorfismos nos genes metabolizadores de estrógenos podem modificar os níveis de danos no DNA tanto em mulheres sadias quanto em mulheres com CM.

\section{ANÁLISE DA EXPRESSÃO GÊNICA PROMÍSCUA NO TIMO DE CAMUNDONGOS NOD (non obese diabetic) DURANTE A EMERGÊNCIA DO DIABETES MELITUS TIPO 1}

\section{Thais Arouca Fornari}

Orientador: Prof.Dr. Geraldo Aleixo da Silva Passos Júnior Dissertação de Mestrado apresentada em 17/03/2008

A tolerância imunológica é a propriedade essencial do sistema imune que controla as reações patológicas contra antígenos do próprio. O timo é visto como o principal órgão envolvido com a indução de tolerância aos antígenos próprios que são expressos pelas células tímicas (tolerância central), enquanto que a indução de tolerância aos antígenos relacionados a outros tecidos (TRAs) tem sido atribuída aos mecanismos de tolerância extratímica (tolerância periférica). Entretanto, a evidência da expressão de TRAs de órgãos e tecidos parenquimais no timo pelas células medulares epiteliais (mTECs) de camundongos e de humanos a qual foi referida como "expressão gênica promíscua" (PGE) reforçou a concepção de tolerância central de TRAs. O controle molecular dessa expressão tem sido atribuído ao gene Aire (Auto immune regulator) que é um regulador de transcrição. No presente estudo, procurou-se retratar a expressão gênica promíscua no timo de camundongos NOD (Non
Obese Diabetic) por meio da análise da expressão gênica em grande escala, ou seja, descrevendo seu transcriptoma usando a tecnologia de cDNA microarrays. Para a análise dos dados utilizamos programas de bioinformática dedicados a microarrays bem como dados de bancos para a caracterização da PGE e susceptibilidade genética ao diabetes melitus do tipo 1 (DM-1). Três conjuntos de resultados puderam ser evidenciados. No primeiro conjunto observou-se a ocorrência da PGE de antígenos tecidos/órgãos parenquimatosos (TRAs) em timos recém removidos e em in vitro em cultura ATOC de camundongos NOD pré-autoimunes e autoimunes (diabéticos). O segundo conjunto de resultados consistiu na análise do efeito da inativação do transcrito de gene Aire na expressão gênica do timo de camundongos NOD in vitro em cultura ATOC. Finalmente, no último conjunto de dados, demonstrou-se que certos genes de TRAs com expressão promíscua, se encontram em regiões cromossômicas de susceptibilidade ao DM-1 (idds). Como três deles (Il-4, Cd4 e Cdk4) são diretamente relacionados com a patogenia do DM-1 em camundongos foi possível estabelecer um paralelo entre PGE e susceptibilidade genética.

\section{POLIMORFISMOS DOS GENES TP53 E MDR-1, SUSCEPTIBILIDADE E RESPOSTA A QUIMIO- TERAPIA NEOADJUVANTE EM PACIENTES COM CÂNCER DE MAMA}

\section{Mônica Beatriz Mayorano}

Orientadora: Profa. Dra. Catarina Satie Takahashi

Tese de Doutorado apresentada em 19/03/2008

O câncer de mama e o segundo tipo de câncer mais freqüente no mundo e o mais comum entre as mulheres. A quimioterapia neoadjuvante tem sido introduzida para di- minuir o tamanho do tumor, permitindo a conservação da mama e ganhando controle sobre possíveis metástases. Polimorfismos em genes envolvidos no reparo do DNA, controle do ciclo celular, apoptose e enzimas do metabolismo e eliminação de drogas, poderiam determinar a susceptibilidade individual ao câncer e a resposta ao tratamento. A proteína p53 e um fator de transcrição envolvido, entre 
outras funções, no processo de apoptose. Por outro lado, a glicoproteína $\mathrm{P}$ e uma proteína de transmembrana responsável pelo efluxo de drogas nas células. Polimorfismos do gene TP53, Arg72Pro e Pro47Ser, tem sido observado alterando o potencial de indução de apoptose; quanto ao polimorfismo C3435T do gene MDR-1, tem demonstrado sua influencia sobre a atividade ou expressão da glicoproteína P. O presente trabalho teve por objetivo investigar se os polimorfismos os genes TP53 e MDR-1 na susceptibilidade de câncer de mama e na resposta a quimioterapia neoadjuvante. Para isso, 116 pacientes com câncer de mama e 120 indivíduos controles foram genotipados pela da técnica de PCRRFLP. Analisando os genes TP53 e MDR-1, as frequiências alélicas e genotípicas encontradas foram similares em pacientes e controles para os polimorfismos Arg72Pro e C3435T; no entanto, para o polimorfismo Pro47Ser só foram observados indivíduos apresentando o genótipo selvagem. Os genótipos homozigotos polimórficos para os genes TP53 e MDR-1 foram mais frequientes nos controles não brancos e com idade maior que 50 anos, respectivamente, sugerin- do uma associação dos respectivos genótipos com etnia e idade. Não foi encontrada associação com as demais variáveis em relação ao risco de câncer de mama. Também não foram observadas associações entre as características prétratamento das pacientes em relação à distribuição dos genótipos. Quanto à resposta a quimioterapia, não houve associação significativa quando as respostas clínicas e patológicas foram avaliadas. Porem, na distribuição do número de linfonodos, encontraram-se freqüências aumentadas nos genótipo Pro/Pro do gene TP53 para 1-3 linfonodos metastáticos e no genótipo TT do gene MDR-1 para $\geq 4$ linfonodos axilares metastáticos. Com base nesses dados, não foi possível estabelecer associações entre os polimorfismos e a susceptibilidade ao desenvolvimento de câncer de mama, como também não foi possível determinar sua relação com a resposta à quimioterapia neoadjuvante na nossa amostra. No entanto, mais estudos devem ser feitos para determinar a contribuição destes polimorfismos no câncer de mama e seu tratamento, e assim estabelecer estratégias de quimioterapia mais eficazes.

\section{O PAPEL MODULADOR DO GENE AIRE (AUTOIMMUNE REGULATOR) SOBRE REDES DE EX- PRESSÃO GÊNICA EM CÉLULAS TÍMICAS EPITELIAIS MEDULARES}

\author{
Claudia Macedo \\ Orientador: Prof.Dr. Geraldo Aleixo da Silva Passos Júnior \\ Tese de Doutorado apresentada em 28/03/2008
}

A expressão de antígenos restritos a tecidos (TRAs do inglês tissue restricted antigens) no timo pelas células epiteliais medulares (mTECs de medullary thymic epithelial cells) é essencial para a tolerância central das células T. Devido à sua heterogeneidade em termos de representação de autoantígenos, esse fenômeno foi denominado como expressão gênica promíscua (PGE de promiscuous gene expression), no qual o gene Aire (de autoimmune regulator) desempenha um papel como principal regulador transcricional positivo sobre um grande conjunto de TRAs dependentes de Aire. A proteína Aire tem a capacidade de interagir com sequiências específicas de DNA desempenhando um papel como regulador direto. Neste estudo utilizamos o mé- todo dos cDNA microarrays para acessar a PGE em células mTEC CD80+ murinas cultivadas in vitro. O agrupamento hierárquico dos dados permitiu a observação de que os genes de TRAs foram diferencialmente expressos. Para testar essa hipótese, inicialmente silenciamos o gene Aire pelo método de RNA interferente (RNAi) nas células mTEC. O agrupamento hierárquico dos dados de cDNA microarray mostrou um conjunto de genes de TRAs dependentes de Aire, os quais foram reprimidos após o silenciamento deste último. Redes gênicas reconstruídas desses dados permitiram a identificação de um nó gênico (Gucy2d) estabelecendo regulação positiva sobre genes downstream nas células mTEC normais. Entretanto, sob efeito do silenciamento de Aire, Gucy2d passou a ser um repressor. Esses resultados evidenciaram que genes da PGE estão conectados em rede, que um nó gênico pode atuar como intermediário no seu controle e que Aire na rede PGE desempenha seu controle como regulador upstream.

\section{HIBRIDAÇÃO GENÔMICA COMPARATIVA EM ENDOMETRIOSE}

\section{Luciana Caricati Veiga Castelli \\ Orientadora: Profa. Dra. Lucia Regina Martelli \\ Tese de Doutorado apresentada em 31/03/2008}

A endometriose é uma doença ginecológica benigna comum, mas agressiva, caracterizada pela presença de teci- do endometrial ectópico. A teoria mais aceita para explicá-la é a teoria de Sampson, na qual o tecido endometrial descamado durante a menstruação sofre refluxo através das tubas uterinas, adere e se prolifera em sítios ectópicos da cavidade peritoneal. Por outro lado, apenas o refluxo tubário não é capaz de estabelecer a doença e vários estudos suge- 
rem uma etiologia multidimensional incluindo fatores hereditários, hormonais e imunológicos. Várias metodologias têm sido propostas com o objetivo de identificar genes candidatos para a endometriose. A hibridação genômica comparativa $(\mathrm{CGH})$ é uma técnica que permite que o genoma inteiro seja analisado em um só experimento, sem a necessidade de cromossomos metafásicos obtidos por cultura celular. Nossa proposta foi avaliar, por CGH, amostras de endometriomas ovarianos e de tecido endometrial eutópico de dez pacientes com diagnóstico firmado de endometriose, para screening do genoma. No grupo eutópico, 6/10 amostras apre- sentaram alterações caracterizadas por perdas ou ganhos de regiões cromossômicas e no grupo ectópico foram encontradas alterações em 7/10 casos. A presença de perdas e ganhos de regiões cromossômicas no endométrio eutópico, histologicamente normal, de mulheres com endometriose ovariana, pode ser considerada como alteração primária ao desenvolvimento da doença. A metodologia de CGH permitiu a detecção das regiões cromossômicas 11q12.3-q13.1, 17p11.1-p12 e 17q25.3-q ter como regiões críticas, direcionando investigações futuras para identificação de genes associados à endometriose.

\section{GINECOLOGIA E OBSTETRÍCIA}

\section{REGULAÇÃO DA CALPAIN5 PELO HOXA10 EM CÉLULAS ENDOMETRIAIS E DECÍDUA E SUA EXPRESSÃ̃O GENÉTICA ANORMAL NA ENDOMETRIOSE E NA PRÉ-ECLAMPSIA}

\section{Ivan Andrade de Araujo Penna}

Orientador: Prof. Dr. Rui Alberto Ferriani

Tese de Doutorado apresentada em 18/01/2008

Introdução: A CALPAIN5 faz parte da família das cisteínas proteases e está relacionada com a regulação de inúmeras funções celulares, entre elas a diferenciação e a apoptose. Estudos com microarrays identificaram a CALPAIN5 como um alvo da ação transcripcional do HOXA10 em úteros de camundongos. No presente estudo avaliou-se a regulação da CALPAIN5 pelo HOXA10 em células endometriais, a expressão da CALPAIN5 no endométrio durante todo o ciclo menstrual, e na decídua do primeiro e terceiro trimestres de gestações normais, e o padrão de expressão anormal desse gene na pré-eclampsia e endometriose.

Material e métodos: Foram obtidas dez biópsias endometriais (cinco na fase proliferativa e cinco na fase secretora) de pacientes férteis. Biópsias de lesões de endometriose, confirmadas por histopatologia, foram retiradas de dez mulheres durante procedimento vídeo-laparoscópico. Amostras de decídua foram coletadas em três diferentes ocasiões: três amostras do primeiro trimestre, cinco amostras no terceiro trimestre e cinco amostras de pacientes com pré-clâmpsia no terceiro trimestre. Identificou-se a proteína da CALPAIN5 utilizando imunohistoquímica (IHC) no endométrio eutópico, ectópico e na decídua. Os resultados da IHC foram quantificados, a partir de dois diferentes observadores, utilizando-se Hscore para células estromais, epiteliais e deciduais. Transfeccionou-se 4,0 $\mu \mathrm{g}$ de pcDNA/

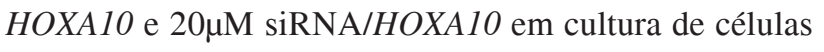
estromais endometriais humanas (HESC) e células epiteliais endometriais humanas (Ishikawa), assim como os seus respectivos controles. A transfecção foi realizada em quadruplicata quando a cultura de células apresentava confluência de 60-70\%. Após 48 horas do procedimento o RNA foi extraído, que deu origem a DNA complementar e após uma reação de cadeia da polimerase em tempo real (PCR em tempo real) foi realizada, em triplicata, para determinar o padrão de expressão do HOXA10 e CALPAIN5. A análise estatística foi realizada utilizando-se os testes ANOVAcom test pos-hoc para o Hscore e teste $t$ para os resultados da PCR em tempo real. Foram obtidas dez biópsias endometriais (cinco na fase proliferativa e cinco na fase secretora) de pacientes férteis. Biópsias de lesões de endometriose, confirmadas por histopatologia, foram retiradas de dez mulheres durante procedimento vídeo-laparoscópico. Amostras de decídua foram coletadas em três diferentes ocasiões: três amostras do primeiro trimestre, cinco amostras no terceiro trimestre e cinco amostras de pacientes com préclâmpsia no terceiro trimestre. Identificou-se a proteína da CALPAIN5 utilizando imunohistoquímica (IHC) no endométrio eutópico, ectópico e na decídua. Os resultados da IHC foram quantificados, a partir de dois diferentes observadores, utilizando-se Hscore para células estromais, epiteliais e deciduais. Transfeccionou-se 4,0 $\mathrm{gg}$ de pcDNA/ HOXA10 e $20 \mu \mathrm{M}$ siRNA/HOXA10 em cultura de células estromais endometriais humanas (HESC) e células epiteliais endometriais humanas (Ishikawa), assim como os seus 
respectivos controles. A transfecção foi realizada em quadruplicata quando a cultura de células apresentava confluência de 60-70\%. Após 48 horas do procedimento o RNA foi extraído, que deu origem a DNA complementar e após uma reação de cadeia da polimerase em tempo real (PCR em tempo real) foi realizada, em triplicata, para determinar o padrão de expressão do HOXA10 e CALPAIN5. A análise estatística foi realizada utilizando-se os testes ANOVA com test pos-hoc para o Hscore e teste $t$ para os resultados da PCR em tempo real.

Resultados: CALPAIN5 é expressa durante todo o ciclo menstrual tanto nas células estromais como epiteliais glandulares, e está mais expressa na decídua do primeiro trimestre. Na endometriose CALPAIN5 se mostrou pouco evidente em ambas as células endometriais (estromais e glandulares), quando comparadas de forma geral com as células endometriais eutópicas das pacientes controles, sendo que sua expressão reduziu em $50 \%(\mathrm{p}<0,05)$. Nas decíduas de pacientes com pré-eclampsia CALPAIN5 apresentou-se mais expressa que no grupo controle $(\mathrm{p}<0,05)$. Nas células estromais endometriais o pcDNA/HOXA10 aumentou a expressão da CALPAIN5 em 11 vezes $(\mathrm{p}<0,05)$ e a transfecção com siRNA/HOXA10 reduziu a expressão da CALPAIN5 em 23 vezes $(\mathrm{p}<0,05)$.

Conclusões: $\mathrm{O}$ HOXA10 regula a expressão genética da CALPAIN5 nas células endometriais. CALPAIN5 é expressa no endométrio normal e tem sua expressão aumentada nas células deciduais do primeiro trimestre em relação às fases do ciclo menstrual. CALPAIN5 está pouco expressa no endométrio ectópico na endometriose e mais expressa nas células deciduais na pré-eclampsia grave quando comparados com seus respectivos controles.

\section{INIBIÇÃO DA QUEBRA DA VESÍCULA GERMINATIVA DE COMPLEXOS CUMULUS-OÓCITO BO- VINOS PELA BUTIROLACTONA I, SEGUIDA POR INDUÇÃO DA MATURAÇÃO in vitro: EFEI- TOS SOBRE O FUSO MEIÓTICO OOCITÁRIO}

\section{Elisa Melo Ferreira}

Orientadora: Profa. Dra. Paula Andrea de A. Salles Navarro

Dissertação de Mestrado apresentada em 29/01/2008

A assincronia entre a maturação nuclear e a citoplasmática e, possivelmente, danos ao fuso meiótico oocitário, limitam a aplicação da maturação in vitro (MIV) em Reprodução Assistida. Estudos sugerem que uma pré-maturação in vitro com bloqueadores da meiose possa melhorar a qualidade oocitária, favorecendo a embriogênese inicial. Assim, investigamos o efeito da pré-maturação com o inibidor de maturação nuclear, Butirolactona I (BL I), sobre o fuso meiótico e distribuição cromossômica de oócitos bovinos. Oócitos imaturos, obtidos de vacas abatidas em matadouro ( $\mathrm{n}=833$ ), foram subdivididos nos grupos: 1 ) controle $(\mathrm{n}=320)$, submetidos apenas à MIV em TCM199, por 24h;2) BL I 18h
( $\mathrm{n}=207)$ submetidos ao bloqueio meiótico com $100 \mu \mathrm{M}$ de BL I, por 24h (pré-maturação) e posterior indução da MIV em TCM199, por 18h; 3) BL I 24h ( $\mathrm{n}=306$ ), pré-maturados com $100 \mu \mathrm{M}$ de BL I, por 24h, seguida por 24h de MIV em TCM199. Em seguida, os oócitos foram fixados, corados por imunofluorescência e avaliados. O bloqueio meiótico ocorreu em $88,8 \%$ dos oócitos cultivados com BL I. As taxas de maturação foram similares entre os grupos $(80,6 \% ; 73,9 \%$ e $82,6 \%$, respectivamente, para controle, BL I $18 \mathrm{~h}$ e BL I 24h). Observamos $82,5 \%$ oócitos normais em metáfase II no controle e $80,0 \%$ e $81,5 \%$ nos grupos BL I $18 \mathrm{~h}$ e BL I $24 \mathrm{~h}$, respectivamente. A incidência de anomalias meióticas não diferiu $(17,5 \% ; 20,0 \%$ e $18,5 \%$, respectivamente, para controle, BL I 2). A BL I bloqueia a meiose, sem promover $18 \mathrm{he}$ BL I 24h). ( $\mathrm{P}<0,05)($ Teste do $\mathrm{x}$ danos ao fuso meiótico e distribuição cromossômica oocitária após a MIV.

\section{AVALIAÇÃO DAS CONCENTRAÇÕES PLASMÁTICAS DA FENTANILA, DOS ENANTIÔMEROS DA BUPIVACAÍNA, DA LIDOCAÍNA E SEU METABÓLITO MONOETILGLICINAXILIDIDA NOS COMPARTIMENTOS MATERNO E FETAL}

\section{Luciana de Barros Duarte}

Orientador: Prof. Dr. Sérgio Pereira da Cunha

Tese de Doutorado apresentada em 07/02/2008

Introdução: A analgesia e anestesia atualmente são um dos procedimentos amplamente utilizados em obstetrícia, realizados algumas vezes através da associação entre os anestésicos locais bupivacaína, lidocaína e o agente opióide fentanila.
Objetivo: Avaliar a distribuição das concentrações da fentanila, enantiômeros da bupivacaína, da lidocaína e seu metabólito monoetilglicinaxilidida nos diferentes compartimentos materno e fetal, com principal ênfase para o espaço interviloso placentário, visto que não existem na literatura dados referentes as concentrações plasmáticas dessas substâncias no espaço interviloso placentário.

Casuística e Métodos: Foram avaliadas 10 gestantes a termo hígidas submetidas a bloqueio epidural. Foram colhidas amostras de sangue materno, espaço interviloso pla- 
centário, veia e artéria umbilical fetal para determinar as concentrações da fentanila, nos diferentes compartimentos materno e fetal, e suas taxas de transferência para o feto. A transferência placentária da fentanila foi avaliada através das razões das concentrações plasmáticas da fentanila na veia umbilical e veia materna assim como as razões entre os diferentes compartimentos materno e fetal.

Resultados: As maiores taxas de transferência placentária foram da fentanila de $86 \%$. Entre os anestésicos locais a bupivacaína apresentou taxas de 33 e $31 \%$ respectivamente para os enantiômeros -(+)-(R) e -(-)-(S) e $60 \%$ e $43 \%$ para a lidocaína e seu metabólito. Entre os enantiômeros da bupivacaína as maiores concentrações foram encontradas no plasma materno e espaço interviloso placentário, assim como a lidocaína e o seu metabólito, sendo as maiores para o enantiômero (-)-(S). As maiores concentrações da fentanila foram encontradas no espaço interviloso placentário. Foram encontradas diferenças estatisticamente significativas entre as concentrações da lidocaína na artéria e veia umbilical fetal, essas diferenças foram atribuídas à captação tecidual fetal da droga ou a metabolização do fármaco pelo feto.

Conclusões: Em relação a fentanila o estudo concluiu, que o espaço interviloso placentário atuou como um depósito da droga. O presente estudo também atribuiu duas possíveis causas para as maiores concentrações dos referidos agentes encontradas no espaço interviloso placentário, em primeiro lugar a ligação das drogas as proteínas teciduais placentárias, e em segundo a origem arterial do sangue colhido no espaço interviloso placentário. Segundo alguns autores as concentrações arteriais desses agentes são maiores quando comparadas às venosas.

\section{ESTUDO FARMACOCINÉTICO E ANÁLISE DA DISTRIBUIÇÃO TRANSPLACENTÁRIA DA LIDO- CAIINA E SEU METABÓLITO NA ASSISTÊNCIA ANESTÉSICA VIA PERIDURAL DE GESTANTES DIABÉTICAS GESTACIONAIS}

Elaine Christine Dantas Moisés

Orientador: Prof. Dr. Sergio Pereira Dantas Moisés

Tese de Doutorado apresentada em 11/02/2008

Introdução: O bloqueio peridural com lidocaína, bupivacaína e fentanila representa um dos procedimentos anestésicos mais utilizados em obstetrícia, fato que justifica o estudo farmacocinético destes fármacos nessas condições.

Objetivos: Os objetivos deste trabalho foram investigar a farmacocinética e a análise da transferência placentária da lidocaína e seu metabólito monoetilglicinaxilidida (MEGX) em gestantes normais e com diabetes mellitus gestacional (DMG), submetidas a anestesia peridural com lidocaína, bem como, avaliar a influência das alterações fisiopatológicas da diabetes gestacional sobre os parâmetros farmacocinéticos desta droga e de seu metabólito.

Casuística e métodos: Foram avaliadas dez gestantes normais (grupo 1) e seis gestantes com DMG (grupo 2), todas de termo. Todas receberam cloridrato de lidocaína a $2 \%$ sem vasoconstrictor, em dose pré-determinada, por via loco-regional peridural. Na sequiência foram coletadas amostras sanguíneas maternas nos tempos 1 minuto, 5, 15, 30, $45,60,120,240,360,480,600,720$ e 840 minutos e amostras de sangue do espaço interviloso placentário, de artéria e veia umbilical para determinação das concentrações de lidocaína e MEGX por cromatografia e a análise farmacocinética. Com base nas concentrações maternas e fetais no momento do nascimento foram determinadas as relações entre os compartimentos maternos e fetais destes fármacos e taxa de extração fetal.

Resultados: As medianas dos parâmetros farmaco- cinéticos da lidocaína para os grupos 1 e 2 foram, respectivamente: Cmax 879,11 e 1145,58 ng/mL, t1/2 $\beta 202,09$ e 272,16 $\min , \beta 0,0034$ e $0,0025 \mathrm{~min}^{-1}, \mathrm{AUC0}^{-\infty} 256013,50$ e 455950,97 ng.min $/ \mathrm{mL}, \mathrm{Cl} / \mathrm{f} / \mathrm{kg} \mathrm{10,61} \mathrm{e} \mathrm{5,64} \mathrm{mL/min/kg,} \mathrm{Vd/f/kg} \mathrm{3255,24}$ e 2188,304 mL/kg. As medianas dos parâmetros farmacocinéticos do MEGX para os grupos 1 e 2 foram, respectivamente: Cmax 82,71 e 141,38 ng/mL, Tmax 44,71 e 193,14 min, $\mathrm{t} 1 / 2 \alpha$ 7,64 e 59,77 min, $\alpha$ 0,097 e 0,012 $\mathrm{min}^{-1}, \mathrm{t} 1 / 2 \beta 247,28 \mathrm{e}$ 492,20 min, $\beta$ 0,0028 e 0,0016 min $^{-1}, \mathrm{AUC0}^{-\infty} 29906,71 \mathrm{e}$ 108229,19 ng.min/mL.

A mediana do tempo de latência entre a administração da droga e o nascimento foi de 28,5 min e 28 min nos grupos 1 e 2, respectivamente. As medianas das relações entre os compartimentos maternos e fetais para a lidocaína nos grupos 1 e 2 foram, respectivamente: relação veia umbilical / sangue materno periférico: 0,60 e 0,46; relação espaço interviloso / materna: 1,01 e 0,88 ; relação artéria umbilical / veia umbilical: 0,77 e 0,91; relação veia umbilical / espaço interviloso: 0,53 e 0,51. As medianas nos grupos $1 \mathrm{e}$ 2 para o MEGX foram, respectivamente: relação feto / materna 0,43 e 0,97; relação espaço interviloso / materna: 0,64 e 0,90; relação artéria umbilical / veia umbilical: 1,09 e 0,99; relação veia umbilical / espaço interviloso: 0,55 e 0,78.

Conclusões: Os dados desse estudo permitem concluir que o clearance aparente da lidocaína e do MEGX mostraram-se reduzidos nas pacientes diabéticas em relação às normais, sugerindo que o DMG inibe as isoformas CYP1A2 / CYP3A4, responsáveis pela metabolização desse fármaco e de seus metabólitos. O DMG não afetou o transporte passivo da lidocaína, porém, interferiu na transferência transplacentária do MEGX, atuando como um mecanismo facilitador para o transporte do mesmo. 


\section{USO DO LETROZOL EM HIPERESTIMULAÇÃO OVARIANA PARA FERTILIZAÇÃO in vitro: ESTUDO DUPLO CEGO RANDOMIZADO}

\author{
Luciana Abreu Álvares da Silva \\ Orientador: Prof. Dr. Marcos Dias de Moura \\ Dissertação de Mestrado apresentada em 15/02/2008
}

Objetivo: Avaliar os efeitos do letrozol em pacientes submetidas à hiperestimulação ovariana com gonadotrofina em ciclo de reprodução assistida.

Desenho: Estudo duplo cego randomizado.

Instituição onde foi realizado: Hospital das Clínicas da Faculdade de Medicina de Ribeirão Preto.

Intervenção: Pacientes em uso de análogo de GnRH, iniciaram letrozol $2,5 \mathrm{mg}$ ou placebo do dia $3^{\circ}$ ao dia $7^{\circ}$ do ciclo, associados à FSH recombinante (FSHr) a partir do dia $3^{\circ}$ do ciclo.

Variáveis estudadas: Quantidade em unidades de FSHr, dias de indução, número de folículos recrutados, espessura endometrial, nível sérico de estradiol, nível de andostenediona e testosterona no fluido folicular.

Resultados: Foram incluídos 40 casais. As mulheres apresentavam idade igual ou inferior a 38 anos, sem endocrinopatias ou cirurgias prévias nos ovários e tinham história de até 3 anos de infertilidade. Foi avaliado um ciclo de hiperestimulação ovariana controlada de cada casal. As pacientes que usam letrozol apresentaram menor nível de estradiol sério e maior nível de testosterona e androstenediona no fluido folicular. Não houve diferença estatística em unidades de FSHr, dias de indução, número de folículos recrutados e espessura endometrial.

Conclusão: A adição de letrozol 2,5 $\mathrm{mg}$ do $3^{\circ}$ ao $7^{\circ}$ do ciclo, associado às gonadotrofinas em ciclos de hiperestimulação ovariana controlada, utilizando protocolo longo com análogo de GNRH, promoveu uma diminuição nos níveis estragênicos séricos, com aumento no níveis de androgênios no fuido folicular sem alterar o padrão clínico de estimulação ovariana.

\section{COMPARAÇÃO DA FUNÇÃO ENDOTELIAL ENTRE MULHERES JOVENS USUÁRIAS DE CON- TRACEPTIVO ORAL COMBINADO (ETINILESTRADIOL E LEVONORGESTREL), CONTRACEP- TIVO INJETÁVEL TRIMESTRAL (ACETATO DE MEDROXIPROGESTERONA) E NÃO-USUÁRIAS}

\section{Patrícia Margareth Lizarelli \\ Orientadora: Profa. Dra. Maristela Carbol Patta \\ Dissertação de Mestrado apresentada em 25/02/2008}

Introdução: O impacto da anticoncepção hormonal nos diversos parâmetros de avaliação endotelial de mulheres saudáveis é ainda pouco estudado e pode haver diferenças entre os diferentes métodos hormonais.

Objetivo: Determinar se há alteração da função endotelial entre mulheres saudáveis usuárias de contraceptivo oral combinado (COC), usuárias de acetato de medroxiprogesterona de depósito (AMP-D) e não usuárias de métodos hormonais por meio da avaliação da dilatação da artéria braquial mediada por fluxo realizada por ultrassonografia bidimensional (DMF).

Método: Estudo transversal com 100 mulheres de 18 a 30 anos de idade, índice de massa corporal entre 18 e 29 $\mathrm{kg} / \mathrm{m}^{2}$, sendo 50 mulheres do grupo controle e 50 usuárias de contraceptivo hormonal há no mínimo seis meses e no

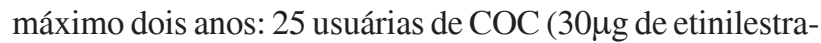
diol e $150 \mu \mathrm{g}$ de levonorgestrel) e 25 usuárias de AMP-D (150mg acetato de medroxiprogesterona). Além da DMF, foram avaliados a pressão arterial, índice de massa corporal, cintura, freqüência cardíaca, espessura íntima média da artéria carótida comum, medida da distensibilidade e do índice de rigidez da artéria carótida e o volume uterino. Marcadores laboratoriais para risco cardiovascular foram realizados, como dosagens séricas de proteína $\mathrm{C}$ reativa ultra-sensível; colesterol total; triglicérides; HDL-colesterol; LDL-colesterol; glicemia de jejum e homocisteína. Para análise estatística utilizou-se o teste ANOVA com pós-teste de Tukey, teste de Kruskal-Wallis com pós-teste de Dunn e teste exato de Fisher.

Resultados: Foi observada uma diferença significativa na DMF entre as mulheres usuárias de $\mathrm{COC}$ em relação às controles $(6.4 \pm 2.2 \%$ x $8.7 \pm 3.4 \%, \mathrm{p}<0.01)$ e também entre as usuárias de AMP-D e as mulheres do grupo controle $(6.2 \pm 2.1 \%$ x $8.7 \pm 3.4 \%, \mathrm{p}<0.01)$. Não houve diferença entre os grupos nos demais parâmetros analisados.

Conclusão: A função endotelial mensurada pela DMF está prejudicada em usuárias de COC $(30 \mu \mathrm{g}$ de etinilestradiol e $150 \mu \mathrm{g}$ de levonorgestrel) e AMP-D (150mg acetato de medroxiprogesterona), podendo estar associada à disfunção endotelial. 


\section{PREDIÇÃO DA RESPOSTA À QUIMIOTERAPIA NEO-ADJUVANTE COM CiclinaD1 E PROTEÍNA p21 NO TRATAMENTO CÂNCER DE MAMA LOCALMENTE AVANÇADO}

\author{
RenatoAntonio Abrão \\ Orientador: Prof.Dr. Jurandyr Moreira de Andrade \\ Dissertação de Mestrado apresentada em 27/02/2008
}

Avaliamos neste estudo as expressões da ciclina D1 e da proteína p21, pela técnica de Imunohistoquímica, para detectar a presença destas proteínas nos núcleos das células do câncer de mama localmente avançado, com o objetivo de correlacionar a concentração destas proteínas com a resposta preditiva ao tratamento quimioterápico neoadjuvante, utilizando o esquema Docetaxel associado à Epirrubicina.

A avaliação foi feita previamente e após a realização da quimioterapia neoadjuvante. A avaliação pré-quimioterápica teve a finalidade de estabelecer um papel preditivo quanto à resposta ao tratamento primário. A avaliação pósquimioterápica teve a finalidade de explorar a relação entre a persistência da proteína com intervalo livre de doença e sobrevida global.

Foram selecionados no ambulatório de Mastologia do Hospital das Clínicas de Ribeirão Preto, no período de janeiro de 1998 a dezembro de 2005, 72 casos de 162 tumores localmente avançados de mama atendidos, tratados por quimioterapia primária.

Conclusão: Nosso estudo concluiu que a ciclina D1 está relacionada com tumores menores, bem diferenciados, e hormônio-sensíveis. Já a proteína p21 está relaciona a tumores pequenos, com estádios iniciais menores, de baixo grau histológico e hormônio-sensíveis. A expressão da ciclina D1 no tumor pré-tratamento quimioterápico não foi capaz de predizer resposta à quimioterapia neoadjuvante. No entanto, a presença da ciclina D1 e no tumor residual e da p21 tanto no tumor pré-tratamento quanto no tumor residual, sugerem melhora no intervalo livre de doença e sobrevida global.

\section{O IMPACTO DA ANSIEDADE E DEPRESSÃO NA QUALIDADE DE VIDA DE MULHERES COM DOR PÉLVICA CRÔNICA}

\section{Adriana Peterson Mariano Salata Romão \\ Orientador: Prof. Dr. Antonio Alberto Nogueira \\ Dissertação de Mestrado apresentada em 28/02/2008}

Introdução: A Dor Pélvica Crônica (DPC) tem sido definida como dor pélvica não exclusivamente menstrual, com duração de pelo menos seis meses, suficientemente intensa que pode interferir em atividades habituais, necessitando de tratamento clínico e/ou cirúrgico. Pacientes portadoras de DPC tem apresentado altos níveis de ansiedade e depressão desta forma tem havido um comprometimento na sua qualidade de vida. Objetivos: verificar o impacto da ansiedade e depressão na qualidade de vida de mulheres com dor pélvica crônica.

Casuísticas e Métodos: foi realizado um estudo do tipo transversal, no qual foram incluídas 52 pacientes com dor e 54 sem dor. A depressão e a ansiedade foram avaliadas pela escala Hospital Anxiety and Depression Scale - HAD e a qualidade de vida foi avaliada pelo World Health Organization Quality of life - Whoqol-bref. Para análise estatística foram utilizados os testes U de Mann-Whitney, Exato de Fisher, $\mathrm{X}^{2}$ e o teste de Spearman.

Resultados: A freqüência de ansiedade nos grupos com dor e controle foram respectivamente $73 \%$ e $37 \%$ ( $\mathrm{p}=0$, 0001) e de depressão foram respectivamente $40 \%$ e $30 \%$ $(\mathrm{p}=0,0269)$. Houve correlação significativa entre os escores de ansiedade e depressão ( $<<0,0001 ; \mathrm{r}=0,6418)$. Quanto aos escores de qualidade de vida observaram-se diferenças significativas entre os domínios físico ( $\mathrm{p}<0,0001$ ), psicológico $(p<0,003)$ e social $(p<0,005)$, não havendo diferenças significativas no domínio ambiental $(\mathrm{p}=0,610)$ entre os grupos. Foram comparadas no grupo com dor, pacientes com e sem ansiedade quanto aos escores de qualidade de vida, observando-se níveis significativamente mais elevados nos domínios físico ( $\mathrm{p}=0,0011)$, psicológico $(\mathrm{p}<0,0001)$, social ( $\mathrm{p}=0$, 0186) e ambiental ( $\mathrm{p}=0,0187)$ nas pacientes sem ansiedade. Neste mesmo grupo, foram comparadas as pacientes com e sem depressão quanto aos escores de qualidade de vida, observando-se níveis significativamente mais elevados para os domínios físico ( $\mathrm{p}=0,003)$, psicológico $(\mathrm{p}<0,0001)$, social $(\mathrm{p}=0,0015)$ e ambiental $(\mathrm{p}=0,0048)$.

Conclusões: As pacientes com DPC apresentam índices de ansiedade e depressão maiores que o grupo controle e a sua qualidade de vida está diminuída. Quanto maiores os escores de ansiedade e depressão, menores os escores de qualidade de vida. Mais estudos são necessários para comprovar efetivamente estas associações. No entanto, uma avaliação bem realizada e o acompanhamento psicológico podem auxiliar no tratamento da dor pélvica crônica, objetivando melhorar a qualidade de vida dessas pacientes. 


\section{CÂNCER DE MAMA LOCALMENTE AVANÇADO: ciclina A E PROTEÍNA p27 PARA PREDIÇÃo DE RESPOSTA À QUIMIOTERAPIA NEOADJUVANTE}

\author{
Willian Simões Clagnan \\ Orientador: Prof. Dr. Jurandyr Moreira de Andrade \\ Dissertação de Mestrado apresentada em 29/02/2008
}

Introdução: a disfunção de proteínas que atuam no controle do ciclo celular está diretamente relacionada ao processo inicial de tumorigênese. A expressão de ciclina A em tumores de mama está relacionada à menor sobrevida livre de doença (SLD) e também à menor sobrevida global (SG). Da mesma maneira, a reduzida expressão de p27 em tumores de mama está relacionada à pior prognóstico. Ambas as alterações têm sido relacionadas com tumores de alto grau histológico, maior diâmetro no momento do diagnóstico e expressão de c-erb-B2. Não há dados referentes à resposta clínica destes tumores ao tratamento neoadjuvante.

Objetivos: o objetivo deste estudo foi analisar as taxas de positividade de expressão de ciclina A e proteína p27 em tumores de mama localmente avançados, antes e após quimioterapia neoadjuvante com Docetaxel $\left(75 \mathrm{mg} / \mathrm{m}^{2}\right)$ e Epirrubicina $\left(60 \mathrm{mg} / \mathrm{m}^{2}\right)$, a relação delas com resposta ao tratamento, SLD e SG.

Metodologia: foram incluídas 92 pacientes tratadas no período entre janeiro de 1998 e dezembro de 2004, com aplicação de pelo menos dois ciclos de quimioterapia neoadjuvante a cada 21 dias e submetidas à cirurgia para tratamento loco-regional. A análise da expressão de ciclina A e p27 foi feita por meio de imunohistoquímica, tendo sido considerados positivos os casos com expressão acima de $30 \mathrm{e}$ $50 \%$, respectivamente.
Resultados: a mediana do número de ciclos de quimioterapia neoadjuvante foi de três (variando entre $2 \mathrm{e} 7$ ) e do tempo de seguimento de 40 meses $(11-100)$. Observamos positividade de ciclina $\mathrm{A}$ antes da quimioterapia em 27 pacientes $(29,3 \%)$ e de p27 em 42 pacientes (45,7\%). Após a quimioterapia, a positividade para ciclina $\mathrm{A}$ foi de $16,3 \%$ (15 pacientes) e de $\mathrm{p} 27$ de 29,3\% (27 pacientes). A expressão de p27 não foi preditiva de resposta clínica ou patológica, SLD e SG. As taxas de resposta clínica foram iguais nas pacientes com e sem expressão de ciclina A antes da quimioterapia e a resposta patológica também foi semelhante. A manutenção de expressão de ciclina A após a quimioterapia esteve associada à menor resposta clínica completa $(6,7$ x 27,3\%,p = 0,04), mas não à resposta patológica. Também esteve relacionada à menor $\mathrm{SLD}(\mathrm{p}=0,006)$ e à menor $\mathrm{SG}(\mathrm{p}$ $=0,003)$. Não observamos relação entre expressão de ciclina A e p27 com acometimento ganglionar, grau histológico, receptores hormonais e c-erb-B2, diâmetro tumoral e estádio clínico. $\mathrm{Na}$ análise multivariada, a idade de menos de 41 anos no diagnóstico, acometimento de dois ou mais gânglios axilares e a expressão de ciclina A após a quimioterapia foram os fatores relacionados a óbito pela doença.

Conclusões: observamos que a manutenção de expressão de ciclina A em tumores de mama localmente avançados após a quimioterapia neoadjuvante está relacionada à pior SLD e SG. Estes achados podem ser explicados pelo fato da expressão desta proteína identificar um grupo de tumores com alto índice de proliferação e maior agressividade. No nosso estudo, a expressão de p27 não foi preditiva de resposta ao tratamento neoadjuvante, SLD ou SG..

\section{ESTUDO DOPPLERVELOCIMÉTRICO DAS ARTÉRIAS RENAIS FETAIS EM GESTAÇÕES NOR- MAIS ENTRE A $22^{\mathrm{a}}$ E A $38^{\mathrm{a}}$ SEMANA}

Francisco Maximiliano Pancich Gallarreta

Orientador: Prof. Dr. Francisco Mauad Filho

Dissertação de Mestrado apresentada em 14/03/2008

O objetivo do estudo foi determinar os valores do tempo de aceleração, da velocidades sistólica máxima e diastólica final, da relação sístole/diástole, do índice de resistência e do índice de pulsatilidade das artérias renais fetais entre a $22^{\mathrm{a}}$ e $38^{\mathrm{a}}$ semanas de gestação. Foi realizado estudo prospectivo e longitudinal no qual 45 fetos de gestantes normais foram entre 22 e 38 semanas de gestação. A idade gestacional foi determinada pelo tempo de amenorréia e/ou pelo exame ecográfico do primeiro trimestre. Os exames ultrasonográficos com Doppler foram realizados por um único observador que utilizou um aparelho modelo ACCUVIX -
MEDISON, com transdutor banda larga. Para a aquisição do traçado Doppler das artérias renais o indicador de amostra foi calibrado para um volume de amostra de 1 a $2 \mathrm{~mm}$ e colocado nas artérias renais no terço médio. $\mathrm{O}$ ângulo de insonação esteve entre $0^{\circ}$ e $52^{\circ}$ e o filtro foi mantido na calibragem 0 ou 1. Observou-se comportamento ascendente das velocidades sistólica máxima e diastólica final e os índices de resistividade demonstraram decréscimo significante ao longo do período avaliado. $\mathrm{O}$ tempo de aceleração das artérias renais demonstrou decréscimo significante ao longo da gestação. A comparação entre os parâmetros Doppler das artérias renais direita e esquerda demonstrou não haver diferença significante. Concluiu-se que houve diminuição do tempo de aceleração, incremento das velocidades sistólica máxima e diastólica final e redução dos índices de resistividade. 


\section{DESENVOLVIMENTO EMBRIONÁRIO in vitro DE OÓCITOS BOVINOS MATURADOS EM SIS- TEMA DE MIV QUIMICAMENTE DEFINIDO COM MACROMOLÉCULAS SINTÉTICAS}

\author{
Alessandra Aparecida Vireque \\ Orientador: Prof. Dr. Rui Alberto Ferriani \\ Tese de Doutorado apresentada em 31/03/2008
}

A procura por condições de cultura mais adequadas e menos variáveis que simulem o ambiente in vivo têm levado ao desenvolvimento de meios de cultura definidos, com menor impacto sobre a reprogramação molecular de oócitos e embriões. Complexos cmulus-oócito bovinos foram cultivados em meio -MEM suplementado com IGF-1 e insulina, e $0.1 \%$ PVA ou $0.1 \%$ PVP. Não foram usados FSH e/ou LH em ambos os tratamentos. O grupo controle consistiu de COCs maturados em TCM com FSH e 10\% de soro de vaca em estro. Após a fertilização, os prováveis zigotos foram co-cultivados com células do cumulus até 224 h pósinseminação (hpi). A produção de esteróides foi mensurada no meio de cultura após a maturação in vitro (MIV) e a atividade de aromatase das células do cumulus (CC) foi estimada pela avaliação da proporção de estradiol (E2) e progesterona (P4). As taxas de clivagem, blastocisto e eclosão foram avaliadas 168-224 horas hpi. Em adição, o RNA total foi isolado de pools de embriões, reversamente transcrito em cDNA, e a expressão relativa dos transcritos dos genes Hsp-70 e Bax foram analisados pelo PCR em tempo real e os índices de células apoptóticas em blastocistos eclodidos foram determinados pela reação de TUNEL. Foi detectada elevada atividade de aromatase (E2:P4 ratio > 1.0) no meio de cultura dos sistemas de MIV quimicamente definidos. A taxa de clivagem foi maior $(\mathrm{P}<0,05)$ no grupo controle $(68,3 \%)$ que nos grupos PVA $(54,4 \%)$ e PVP-40 $(58,3 \%)$. Entretanto, não houve diferença $(\mathrm{P}>0.05)$ nas taxas de blastocistos $(40 \% ; 44.6 \%$ and $42.6 \%)$ e eclosão $(36 \%$; $34.62 \%$ and $40.8 \%$ ) entre os grupos PVA, PVP-40 e controle, respectivamente. Similarmente, não foi detectada diferença $(\mathrm{P}>0.05)$ na expressão relativa dos transcritos Hsp-70 e Bax no PVA e PVP-40 em comparação com o calibrador (grupo controle). Não foram observadas diferenças significativas nos índices de núcleos TUNEL positivos entre os blastocistos derivados dos três grupos. Estes resultados indicam que as CC de COCs cultivados em meio suplementado com soro durante a MIV tem reduzida atividade de aromatase e que oócitos bovinos podem ser maturados em meio livre de soro e gonadotrofina, suplementado com IGFI, insulina e PVA ou PVP sem alterar o desenvolvimento pós-clivagem, a expressão de genes associados ao estresse e o índice apoptótico dos embriões.

\section{IMUNOLOGIA BÁSICA E APLICADA}

\section{LEUCOTRIENOS NA RESPOSTA IMUNE INATA E ADAPTATIVA. MODELO EXPERIMENTAL DE HISTOPLASMOSE PULMONAR}

\section{Adriana Secatto}

Orientadora: Profa. Dra. Alexandra Ivo de Medeiros

Dissertação de Mestrado apresentada em 15/01/2008

O Histoplasma capsulatum é um fungo dimórfico, patogênico e responsável por graves lesões pulmonares, as quais se caracterizam pelo acúmulo de leucócitos ao redor do fungo, resultando na formação de granulomas. A infecção ocorre principalmente pela inalação de conídios ou pequenos fragmentos de micélio que alcançam os alvéolos, onde se transformam em leveduras, que é a forma patogênica do fungo. Recentemente, nós e outros grupos demonstraram a participação de leucotrienos (LTs) nos mecanismos de defesa do hospedeiro contra agentes infecciosos. No presente trabalho, nós descrevemos a importância de LTs na regulação da resposta imune in vivo e in vitro. Os resultados obtidos demonstram que LTs têm importante papel na resposta imune protetora, sendo que a ausência deste mediador em animais 5- $\mathrm{LO}^{-/-}$resultou na disseminação e morte $100 \%$ dos animais. Além disso, a ausência de LTs resultou no (i) aumento da síntese de citocinas pró-inflamatórias e IFN- $\gamma$, (ii) aumento no recrutamento de neutrófilos (iii) diminuição da ativação de células TCD4 ${ }^{+}$e TCD8 ${ }^{+}$efetoras no pulmão, (iv) diminuição da síntese de óxido nítrico e (v) diminuição da fagocitose por macrófagos alveolares infectados com leveduras de H.capsulatum opsonizadas com IgG. Nossos resultados sugerem que leucotrienos têm papel importante na defesa do hospedeiro contra infecção por H.capsulatum demonstrando nova função de molécula reguladora na modulação de célula T durante a infecção. 


\section{AVALIAÇÃO DE DIFERENTES CÉLULAS APRESENTADORAS DE ANTÍGENO EM VACINAS DE DNA - PAPEL DA CÉLULA B NESSE MODELO}

\author{
Luciana Previato de Almeida \\ Orientadora: Profa. Dra. Arlete A. M. Coelho-Castelo \\ Dissertação de Mestrado apresentada em 17/01/2008
}

Embora as células B sejam importantes células apresentadoras de antígeno, ainda é desconhecido seu papel em modelo de vacinação com DNA. Nesse trabalho foi demonstrado que células B podem atuar como apresentadoras de antígenos in vitro e in vivo após a vacinação com DNA, usando como modelo o plasmídeo pcDNA3-hsp65. Após a imunização intramuscular, a ativação das subpopulações de linfócitos T CD4 e T CD8 com perfil de Th1, Th2 ou regulatória apresentaram uma cinética que está relacionada ao tempo após o final do processo de vacinação e também com a APC em questão. Desse modo quinze dias após o termino da vacinação as principais APCs são células dendríticas e linfócitos $\mathrm{B}$. As células dendríticas ativaram linfócitos TCD4 FoxP3+ enquanto os linfócitos B ativaram ambas populações com perfil diferente T CD8 GATA3+ e TCD4 FoxP3+. Trinta dias após, as principais células apresentadoras são macrófagos que induzem uma população de linfócitos TCD4 FoxP3+, enquanto os linfócitos B ativam TCD8 que expressam t-bet. Para verificar a importância das células B nesse modelo, realizou-se a transferência adotiva de linfócitos B eletroporados com o plasmídeo ou vetor para animais deficientes ou não de células B. A transferência dos linfócitos B eletroporados com plasmideo HSP65 induziu a ativação de linfócitos T CD8 de memória com fenótipo CD44 ${ }^{\mathrm{hi}} \mathrm{CD} 62^{\mathrm{hi}}$. Esses animais mostraram uma redução no número de UFC após o desafio com $M$. tuberculosis quando comparados as selvagens, sugerindo a importância dessas células na indução de células T CD8 e o clearance da bactéria. Por outro lado, a análise histológica do pulmão desse grupo de animais mostrou intenso infiltrado inflamatório em relação aos demais grupos. Como o processo de obtenção de células B a serem transferidas exclui o pool de células $\mathrm{B}$ com atividade regulatória. Esse dado nos permite inferir que o resultado observado foi devido a ausência das células B regulatórias que, se presentes, apresentariam papel imunomodulador no controle dos linfócitos B. Assim, embora as células B sejam importantes para indução de proteção após vacinação com DNA plasmideal, também necessitam de controle, para evitar resposta imune exacerbada. Os dados sobre a cinética de ativação de linfócitos T após a vacinação intramuscular são inéditos e, em conjunto, abrem perspectivas para diferentes intervenções vacinais.

\section{ANÁLISE DA EXPRESSÃO GÊNICA PROMÍSCUA NO TIMO DE CAMUNDONGOS DBA-1/J E DBA-2/J DURANTE A IMUNIZAÇÃO COM COLÁGENO: MODELO DE SUSCEPTIBILIDADE/RE- SISTÊNCIAAARTRITE REUMATÓIDE}

\section{Paula Barbim Donate \\ Orientador: Prof.Dr. Geraldo Aleixo da Silva Passos \\ Dissertação de Mestrado apresentada em 25/02/2008}

A artrite reumatóide é uma doença auto-imune sistêmica de etilogia desconhecida, que acomete preferencialmente o sistema locomotor (articulações). Caracterizada por um intenso processo inflamatório na sinóvia, diversas citocinas e mediadores inflamatórios estão envolvidos, podendo causar destruição óssea e articular. A artrite induzida por colágeno é um modelo animal amplamente utilizado por suas características fisiopatológicas muito similares à doença em humanos. A linhagem de camundongos DBA-1/J desenvolve a doença após imunização e booster com colágeno do tipo II, enquanto que a linhagem DBA-2/J se mostra refratária. Isso confere um sistema modelo de susceptibilidade/resistência à artrite, que pode ser estudado em diferentes abordagens. $\mathrm{O}$ fenômeno de expressão gênica promíscua no timo (PGE), foi caracterizado recentemente como a capacidade das células epiteliais tímicas, especialmente as medulares (mTECs), de apresentar antígenos ectópicos tecido-específicos aos timócitos durante seu processo de seleção intra-tímica. Assim a PGE tem sido diretamente relacionada à tolerância central, ou seja, aos mecanismos de discriminação do próprio-não-próprio, estabelecendo uma ligação com o complexo e ainda não muito bem entendido processo de auto-imunidade. Estima-se que o pool de genes promíscuos representa $5-10 \%$ de todos os genes funcionais conhecidos, e a maioria, se não todos, os órgãos parenquimais. Grande parte destes genes parece estar sob influência de um controlador transcricional chamado Aire (autoimmune regulator). O gene Aire é expresso principalmente em células mTEC, e foi, no presente trabalho, alvo de inibição utilizando-se a técnica de RNA interferente (RNAi anti-Aire) em ATOC (Adult Thymus Organ Culture). Com o intuito de se avaliar o comportamento da PGE no modelo de susceptibilidade/resistência à artrite, foi utilizado a tecnologia de cDNA microarrays, que incluiu os programas de bioinformática, SAM (Significance Analysis of Microarrays) e Cluster e TreeView, e o banco de dados Symatlas 
para análise dos dados. Os resultados mostraram que a susceptibilidade a AR característica da linhagem DBA-1/J, pode ocorrer devido às alterações da PGE, caracterizadas pela redução da expressão de genes de antígenos relacionados a tecidos (TRAs) no timo, incluindo aqueles do sis- tema locomotor. Isto poderia afetar o processo de seleção negativa implicado num aumento de linfócitos auto-reativos na periferia. Além disto, houve um descontrole da PGE após silenciamento parcial do transcrito do gene Aire em ATOC utilizando-se a técnica de RNAi (RNA interferente).

\section{AVALIAÇÃO DO PAPEL DE MASTÓCITOS E HISTAMINA NA RESPOSTA IMUNE NA TUBERCU- LOSE EXPERIMENTAL MURINA}

\section{Daniela Carlos}

Orientadora: Profa. Dra. Lúcia Helena Faccioli

Tese de Doutorado apresentada em 26/02/ 2008

A tuberculose (TB) é uma doença pulmonar que se caracteriza por uma reação inflamatória aguda seguida de uma fase crônica com predominância de lesões granulomatosas. As características da imunidade celular do hospedeiro determinam o grau das manifestações clínicas na tuberculose, sendo a interação entre células T e macrófagos, que são as principais células efetoras que participam desta infecção, fundamental para o controle desta doença. Entretanto, outros tipos celulares como células dendríticas, células endoteliais, e mais recentemente mastócitos parecem estar envolvidos nos mecanismos imunológicos desencadeados como decorrência da infecção pelo M. tuberculosis (MTB).

Na primeira fase do nosso trabalho, investigamos o papel dos mastócitos na fase aguda da infecção por MTB. Por isso, foram utilizados camundongos infectados, tratados ou não com composto 48/80, um agente farmacológico que causa a desgranulação de mastócitos. Após 15 dias de infecção, ocorreu intensa reação inflamatória pulmonar, com predomínio de neutrófilos e células mononucleares decorrente da produção de mediadores tais como TNF- $\alpha$, IL-1, IL-6, KC, MCP-1 e MIP-2 no local inflamado. Todavia, após a desgranulação de mastócitos com composto 48/80, houve diminuição marcante do recrutamento das células inflamatórias para o espaço broncoalveolar, sendo que este evento se correlacionou com a queda na liberação dos mediadores pró-inflamatórios nos pulmões. Adicionalmente, mostramos que a desgranulação dos mastócitos de animais infectados induziu redução na síntese das citocinas da resposta imune celular e maior número de UFC foi recuperado nos pulmões destes animais.

Em etapa posterior, elucidamos a importância de TLR2 na ativação dos mastócitos na fase crônica da infecção por MTB. Após 60 dias de infecção, animais TLR2 ${ }^{-/}$apresentaram declínio do número de neutrófilos e células mononucleares no LBA decorrente de ineficiente produção de mediadores pró-inflamatórios como TNF- $\alpha$, IL-1 e IL-6 nos pulmões. Todavia, após infusão sistêmica de mastócitos, houve normalização do recrutamento de células inflamatórias, sendo que este evento correlacionou com aumento da liberação de mediadores pró-inflamatórios nos pulmões. Adicionalmente, mostramos que a transferência adotiva de mastócitos em animais TLR2 ${ }^{-/}$infectados induziu elevação dos níveis das citocinas da resposta imune celular tais como IL-12, IFN- $\gamma$ e IL-10, restabelecimento da formação de granulomas e menor número de UFC foi recuperado nos pulmões. Também verificamos que animais TLR2 ${ }^{-/-}$infectados apresentaram deficiência no influxo de linfócitos $\mathrm{CD}^{+}$, mas na presença de mastócitos positivos para TLR2 houve reversão da capacidade destas células em migrarem para o foco infeccioso. Assim, estes resultados complementares pressupõem que a ativação de mastócitos dependente de TLR2 representa um mecanismo efetor no controle da infecção crônica por MTB.

O principal componente dos grânulos de mastócitos é a histamina, uma amina vasoativa produzida sob à ação da enzima histidina descarboxilase. Entretanto, alguns estudos recentes têm relatado a importância da histamina na defesa do hospedeiro contra infecções. Por isso, resolvemos explorar o papel da histamina nos mecanismos de defesa durante a infecção por MTB usando camundongos deficientes da enzima histidina descarboxilase $\left(\mathrm{HDC}^{-/ /}\right) \mathrm{e}$ também realizamos o tratamento dos animais infectados com antagonistas de receptores para histamina (HR). De acordo com os resultados, o tratamento dos animais infectados com pirilamine (antagonista do H1R) ocasionou menor infiltrado inflamatório no LBA acompanhado de queda da liberação de KC e MIP-2, decréscimo da síntese de IL-12 e aumento dos níveis de IL-10, que resultou em preservação do parênquima pulmonar. Por outro lado, observamos intensa reação inflamatória, elevação da síntese de TNF- $\alpha$, IFN- $\gamma$ e NO após o tratamento com cimetidine (antagonista do H2R), que culminou em injúria pulmonar. Os resultados também comprovaram que histamina é liberada após infecção por MTB e que camundongos $\mathrm{HDC}^{-/-}$exibiram redução da carga bacilar associada ao aumento do infiltrado linfocítico, modulação das citocinas TNF- $\alpha$ e IL-6, amplificação da resposta Th1 e da atividade microbicida de macrófagos.

Assim, o presente projeto, através de abordagens experimentais múltiplas e consistentes, suporta idéias postuladas da literatura, de que mastócitos e seus mediadores, principalmente a histamina, medeiam eventos importantes da resposta imune inata e adaptativa na TB experimental. 
ESTUDO DOS TRANSCRIPTOMAS DE GLÂNDULAS SALIVARES DO CARRAPATO DO BOI, Rhipicephalus (BOOPHILUS) microplus, ALIMENTADOS EM BOVINOS RESISTENTES OU SUSCETÍVEIS PARA OBTENÇÃO DE CATÁLOGO DE GENES AFETADOS PELA RESPOSTA IMUNE DO HOSPEDEIRO

\section{Sandra Regina Costa Maruyama}

Orientadora: Profa. Dra. Isabel Kinney F. de M. Santos

Dissertação de Mestrado apresentada em 26/02/2008

Carrapatos Rhipicephalus (Boophilus) microplus causam enormes prejuízos à saúde e produção animal. Induzem resposta imune em seus hospedeiros mostrando que o controle imunobiológico é possível, sendo que os bovinos apresentam fenótipos contrastantes e herdáveis quanto à intensidade de infestações com carrapatos sendo esses fenótipos mediados por respostas imunes qualitativamente diferentes. Carrapatos alimentados em bovinos resistentes não completam a refeição de sangue, apresentando menor eficiência reprodutiva. A hipótese de trabalho é a de que os diferentes níveis de imunidade anti-carrapato do hospedeiro afetam a expressão de genes na glândula salivar do parasito, órgão que facilita a hematofagia. Assim, o objetivo deste trabalho foi identificar genes do carrapato bovino cuja expressão seja afetada pelas respostas imunes de hospedeiros bovinos resistentes e suscetíveis. Para isso, Expressed Sequence Tags (ESTs) de bibliotecas de cDNA de glândulas salivares (ninfas, machos e fêmeas) e larvas não alimentadas foram analisadas por meio de bioinformática. Um programa específico, Count Libraries, compara a expressão de genes nas diferentes bibliotecas mostrando quantas ESTs de cada biblioteca existem em um contig. O peptídeo sinal, indicativo de secreção, foi detectado com Signal P 3.0 Server. As buscas por similaridades foram feitas nos bancos de dados públicos NR - proteína (NCBI), GO, KOG,
P-fam, SMART, rRNA (NCBI) e MIT-PLA (NCBI) e outros bancos de dados personalizados, como Arachnida e BEA. As 7.923 ESTs foram clusterizadas em 3.342 contigs, sendo que $14 \%$ destes são preditos como sendo secretados e a princípio 20\% são genes novos (nenhuma similaridade com as bases de dados). Vários contigs apresentaram expressão diferencial e os mais abundantes foram agrupados de acordo com sua função putativa em: Proteases e Inibidores de proteases, Alérgenos, Peptídeos antimicrobianos, Anti-inflamatórios, Ligante de IgG, Proteínas ricas em Glicinas, Exoesqueleto e outras menos abundantes. Os resultados mostraram que ESTs com similaridade a alérgenos, estão em maior quantidade em carrapatos alimentados em hospedeiros resistentes (raça Nelore); proteases e inibidores de proteases envolvidos no processo de coagulação sanguínea e degradação de matriz extracelular, proteínas ricas em glicina envolvidas na fixação do carrapato e cutícula (exoesqueleto) estão expressas em maior quantidade nos carrapatos alimentados em hospedeiros suscetíveis (raça Holandesa). Sugerimos que estes últimos grupos de genes, que estão mais expressos em carrapatos alimentados em hospedeiros suscetíveis facilitem a hematofagia do ectoparasita contribuindo para o sucesso reprodutivo da espécie, enquanto que carrapatos alimentados em hospedeiros resistentes, por não expressarem esses genes em quantidades suficientes, não conseguem completar a refeição sanguínea eficientemente e em consequiência têm a reprodução prejudicada. Desse modo, concluímos que a expressão gênica em $R$. microplus é afetada pela resposta imune do hospedeiro.

\section{NEUROLOGIA}

\section{ADAPTAÇÃO CULTURAL PARA A LÍNGUA PORTUGUESA NO BRASIL E TESTE DE SUAS PROPRIEDA- DES PSICOMÉTRICAS}

\section{Flávia Oliveira Toledo}

Orientadora: Profa. Dra. Cláudia Ferreira da Rosa Sobreira Dissertação de Mestrado apresentada em 16/01/2008

O Inventário Breve da Dor (IBD) é um instrumento multidimensional de medida da dor curto, de fácil entendimento, completo e de fácil aplicação em um grande número de pacientes. O IBD vem sendo aplicado para avaliar a dor do câncer e também na avaliação da dor em doenças neuro- musculares. É um questionário que avalia as dimensões relacionadas à intensidade da dor e à interferência da dor na vida do indivíduo. Avalia também aspectos como, por exemplo: a localização da dor, tratamentos ou medicação para o alívio da dor e o quanto de alívio que estes recursos proporcionaram. Os objetivos do presente estudo foram adaptar culturalmente o IBD para a língua portuguesa e testar a validade em uma amostra de brasileiros com doença muscular. Inicialmente o IBD foi submetido a um processo de adaptação cultural, que se constituiu da sua tradu- 
ção para a língua portuguesa realizada por dois tradutores brasileiros com conhecimento da língua inglesa; síntese das traduções e obtenção de uma versão em português através do consenso dos tradutores, chamada de IBD-VPC; avaliação desta versão por um comitê de juízes (fisioterapeutas e médicos neurologistas) e aplicação da versão traduzida em um grupo piloto $(n=40)$ com diagnóstico definido ou em processo de investigação de doença muscular com o intuito de identificar palavras que geravam confusão por parte dos pacientes e outras dificuldades no preenchimento do instrumento. As modificações necessárias foram realizadas e a partir daí, foi obtida a versão adaptada final do IBD (IBD-VPCF). Em seguida, foi realizada a retro-tradução da IBD-VPCF para a original por uma tradutora com domínio da língua inglesa com conhecimento das culturas brasileira e americana. A etapa seguinte foi realizar a comparação das duas versões (adaptada e original) em inglês pelas pesquisadoras principais do estudo. A partir deste momento, a versão adaptada final do IBD foi aplicada na população-alvo $(n=100)$. Primeiramente, o paciente respondia o IBD (teste), depois o Questionário de Qualidade de Vida Relacionada à Saúde (SF-36) e por último o IBD (reteste). Participaram do estudo 100 pacientes, sendo $52(52 \%)$ do sexo feminino e 48 (48\%) do sexo masculino, com idade variando de 20 a 74 anos (MD = 42 anos e $\mathrm{DP}=11,30)$. Para testar a validade do IBD versão adaptada foi realizada análise fatorial que determinou os fatores: intensidade da dor e interferência da dor na vida do indivíduo. A análise da validade convergente com a correlação dos domínios do IBD com os domínios do questionário SF - 36 apresentou valores altos e significativos $(\mathrm{p}<0,01$ e $\mathrm{p}<0,05)$. Para análise da confiabilidade do instrumento adaptado, o alfa de Cronbach foi calculado separadamente para cada fator. Os valores de alfa foram 0,73 para intensidade da dor e 0,78 para interferência na vida, valores considerados de alta consistência interna do instrumento adaptado. Para a análise da confiabilidade intra-observador $(n=100)$ e a confiabilidade interobservador $(n=14)$ os valores para ambas as correlações foram altos e significativos $(\mathrm{p}<0,001)$. Portanto, concluímos que a versão adaptada do IBD para a língua portuguesa no Brasil mostrou-se válida e confiável na avaliação da dor crônica de brasileiros com doença muscular.

\section{ESTUDO NEUROMORFOLÓGICO E COMPORTAMENTAL DO EFEITO DO TRATAMENTO CRÔ- NICO COM PAROXETINA OU ALPRAZOLAM SOBRE COMPORTAMENTOS DEFENSIVOS EVO- CADOS DURANTE O CONFRONTO ENTRE Mesocricetus auratus E A SERPENTE CORAL VENE- NOSA (Micrurus frontalis)}

\section{Tatiana Paschoalim Maurin}

Orientador: Prof. Dr. Norberto Cysne Coimbra

Tese de Doutorado apresentada em 22/01/2008

Este trabalho, utilizando um modelo experimental inovador, baseado no confronto entre roedores e serpentes corais, pretende estudar as diversas reações comportamentais que têm sido relacionadas ao medo e ao pânico, assim como também investigar o efeito de drogas que agem no sistema serotoninérgico, a paroxetina, e no sistema GABAérgico/benzodiazepínico, o alprazolam, sobre o medo inato evocado em situações de perigo iminente. As bases neurais do comportamento de defesa e os alvos farmacológicos das drogas em estudo foram estudados pela imunolocalização da proteína Fos, um marcador molecular da atividade neuronial, em estruturas que compõem o sistema encefálico da aversão, proposto por Graeff, em 1990. Utilizaram-se serpentes corais da espécie Micrurus frontalis que, embora ofiófaga, aparenta um predador de pequenos roedores como a serpente Oxyrhopus guibei, muito embora seja mais ativa no período noturno que esta última espécie, o que estimulou os hamsters Mesocricetus auratus presentemente utilizados como "presas" em potencial, a evocarem padrões de comportamentos defensivos relacionados na literatura com sensações de medo e de pânico.

Curiosamente, as serpentes corais venenosas, $M$. frontalis, evocaram respostas de defesa mais intensas do que a serpente coral falsa, O. guibei. Desta forma a $M$. frontalis foi selecionada para os experimentos ulteriores, mesmo porque seu padrão de movimentação pela arena foi mais constante do que o da $O$. guibei. O confronto com a $M$. frontalis evocou comportamentos defensivos característicos da espécie, como alerta defensivo, congelamento e fuga, além de comportamento de avaliação de risco, sustos e saltos. Houve um aumento da expressão de c-Fos em núcleos amigdalinos, hipotalâmicos e nas colunas dorsal e lateral da SCP. O tratamento agudo com paroxetina e alprazolam causou efeito ansiolítico reduzindo as respostas de avaliação de risco e aumentando o tempo de interação com a serpente coral venenosa. $\mathrm{O}$ tratamento crônico com ambos os antagonistas farmacológicos causou um claro efeito antiaversivo ou efeito antipânico, diminuindo a intensidade das respostas de alerta defensivo, imobilidade defensiva, e de comportamento de fuga, além de aumentar o comportamento de interação com a serpente, reduzindo as respostas de avaliação de risco. Esses efeitos foram seguidos de uma diminuição da atividade de protooncogenes em estruturas prosencefálicas, diencefálicas e mesencefálicas envolvidas com a elaboração de comportamento de defesa evocados diante da serpente coral venenosa. Os presentes resultados sugerem o envolvimento do sistema serotoninérgico e do sistema GABAérgico/benzodiazepínico na atividade panicolítica do tratamento crônico com paroxetina e alprazolam e valida farmacologicamente o presente modelo experimental 


\section{ESTUDO COMPARATIVO, MORFOLÓGICO E MORFOMÉTRICO, DO NERVO SURAL DE RATOS NORMOTENSOS, ESPONTANEAMENTE HIPERTENSOS (SHR) E ESPONTANEAMENTE HIPER- TENSOS ASSOCIADOS AO MODELO DE diabetes mellitus INDUZIDO EXPERIMENTALMENTE PELA STREPTOZOTOCINA (STZ)}

\author{
Marcelo Rodrigo Tavares \\ Orientadora: Profa. Dra. Valéria Paula Sassoli Fazan \\ Tese de Doutorado apresentada em 14/02/2008
}

A hipertensão é duas vezes mais comum em diabéticos do que na população em geral, e os diabéticos com hipertensão apresentam um risco muito maior de doença cardiovascular, quando comparados com diabéticos normotensos ou mesmo hipertensos não diabéticos. A neuropatia periférica é uma das principais complicações neurológicas do diabetes e pode estar relacionada com causas vasculares. Entretanto, causas metabólicas não podem ser descartadas. Embora a associação da hipertensão com o diabetes seja comum na prática clínica, não se sabe, ao certo, qual a contribuição de cada uma dessas doenças no desenvolvimento de neuropatias em pacientes hipertensos diabéticos. Modelos animais de hipertensão arterial e diabetes foram desenvolvidos para a investigação da fisiopatologia e das complicações dessas duas doenças, separadamente ou associadas. Entretanto, não encontramos relatos na literatura sobre descrições morfológicas de nervos periféricos em modelos experimentais que contemplem ambas as condições. Dessa forma, nossos objetivos foram investigar a presença de neuropatia periférica, através da análise morfológica e morfométrica do nervo sural de ratos espontaneamente hipertensos (SHR) e espontaneamente hipertensos com diabetes crônico induzido experimentalmente. Induzimos o diabetes em SHR fêmeas através da administração, em dose única de estreptozotocina (STZ) endovenosa 12 semanas antes dos experimentos. SHR contro- les e ratos normotensos da linhagem Wistar-Kyoto (WKY) receberam somente o veículo. No dia do experimento, após a medida indireta da pressão arterial e frequiência cardíaca, os animais foram perfundidos com solução fixadora e os nervos surais direito e esquerdo foram retirados e preparados para estudos de microscopia de luz. Nossos resultados mostraram que, de maneira geral, os nervos surais de ratos WKY e SHR são simétricos tanto longitudinalmente quanto lateralmente. A morfologia geral dos segmentos proximais e distais do nervo sural de ratas da linhagem WKY não difere daquela de outros nervos em geral, bem como do nervo sural de outras linhagens de ratos ou de outros animais. A hipertensão foi capaz de alterar a morfologia e a morfometria dos fascículos e das fibras mielínicas dos nervos surais de ratas SHR. As principais alterações encontradas foram vasos capilares endoneurais colabados e com paredes espessas, redução do número de núcleos de Células de Schwann, redução da frequiência de aparecimento de fibras mielínicas com diâmetros entre 4 e $6 \mu \mathrm{m}$ e desvio do histograma da razão $\mathrm{G}$ para a direita. Concluímos portanto, que o diabetes crônico, induzido experimentalmente, pela injeção endovenosa única de STZ, foi capaz de promover uma neuropatia do tipo axonial, associada a uma provável neuropatia de fibras finas, nos nervos surais de ratas SHR, acentuando as diferenças observadas entre os animais normotensos e hipertensos. Essa neuropatia foi similar nos segmentos proximais e distais, bem como nos lados direito e esquerdo desses nervos. Foi verificada alterações morfológicas em ambas as patologias isoladamente, e ainda um aumento dessas alterações na associação das mesmas.

\section{CARACTERIZAÇÃO FENOTÍPICA DOS CASOS DE POLINEUROPATIA AMILOIDÓTICA FAMI- LIAR TTRMET30 DE INÍCIO TARDIO}

\section{Maurício Fernandes de Oliveira \\ Orientador: Prof. Dr. Wilson Marques Júnior \\ Dissertação de Mestrado apresentada em 22/02/2008}

A polineuropatia amilóide familiar (PAF) portuguesa foi descrita por Andrade em 1952, sendo entidade clínica prevalente em países como Japão, Suécia e Portugal. Em nosso meio, tem sua distribuição relacionada à migração portuguesa. Iniciando-se classicamente no adulto jovem, pode ocasionalmente manifestar-se mais tardiamente, dificultando o diagnóstico, principalmente na ausência de história familiar e, conseqüentemente, atrasando o aconselha- mento genético apropriado e diminuindo as chances de se realizar o transplante hepático. O objetivo deste estudo é caracterizar o quadro fenotípico dos pacientes com PAF de início tardio.

Material e métodos: todos os pacientes com o diagnóstico molecular de FAP TTRMet30 confirmado pela Seção de Biologia Molecular do Laboratório de Neurologia Aplicada e Experimental (Faculdade de Medicina de Ribeirão Preto, Universidade de São Paulo), entre 1989 e 2006, totalizando 35 indivíduos, foram incluídos. Esses pacientes foram arbitrariamente divididos em dois grupos, segundo a idade de início dos sintomas, em início clássico ou precoce ( $<50$ anos) e início tardio (>50 anos). A seguir, as caracterís- 
ticas clínicas foram comparadas e estudadas.

Resultados: dos 35 pacientes, 26 tinham início clássico e 9, início tardio. No grupo de início clássico a média de idade dos pacientes ao primeiro sintoma foi de 34,4 anos e houve proporção entre os sexos. O sintoma inicial predominante foi dor, seguindo-se parestesias, disautonomias e hipoestesia tátil. Perda de peso foi referida pela maioria. Entre os de início tardio, a média de idade no primeiro sintoma foi de 60,0 anos e houve franco predomínio do sexo masculino. O sintoma inicial foi parestesia na maioria dos casos, mas outras manifestações de neuropatia periférica também estavam presentes na primeira consulta. Uma me- nor proporção de pacientes relataram perda de peso. A história familiar era conhecida de forma semelhante pelos pacientes nos dois grupos.

Discussão: variabilidade fenotípica nas doenças com herança autossômica dominante são relatadas. Na PAF TTR Met 30 dois grupos podem ser distinguidos, um de início precoce e outro de início tardio. A identificação de fatores genéticos ou ambientais responsáveis resultará em novas perspectivas para a compreensão e tratamento da PAF TTR Met30. O conhecimento dessa variabilidade deve ser considerado na avaliação dos pacientes com neuropatia periférica de fibras predominantemente finas.

\section{OFTALMOLOGIA, OTORRINOLARINGOLOGIA E CIRURGIA DE CABEÇA E PESCOÇO}

\section{HABILIDADES AUDITIVAS DE LOCALIZAÇÃO, MEMÓRIA E FIGURA-FUNDO EM CRIANÇAS RESPIRADORAS ORAIS}

\author{
Andréia Pires Correia \\ Orientadora: Profa. Dra. Myriam de Lima Isaac \\ Dissertação de Mestrado apresentada em 18/01/2008
}

Introdução: A literatura descreve que crianças respiradoras orais podem ter distúrbios de atenção e concentração dentre outros sinais e sintomas. Estes podem comprometer a aprendizagem; o rendimento escolar e acarretar transtornos do processamento auditivo.

Objetivos: Este estudo teve o objetivo de avaliar o desempenho de crianças respiradoras orais para as habilidades auditivas de localização sonora, memória seqüencial verbal e não-verbal e figura-fundo auditiva e detectar possíveis indicadores de transtornos de processamento auditivo.

Casuística e Método: Participaram deste estudo 34 crianças de ambos os gêneros, com a média de idade de 9 anos e 2 meses. Foram constituídos dois grupos um controle (GI) e um de respiradores orais (GII). Os critérios de inclusão no GI foram: ausência de queixas auditivas, não ter antecedentes de otites médias de repetição; não possuir queixas respiratórias, não ter distúrbios de linguagem e de fala e saber ler. Os critérios de inclusão no GII foram: ausência de queixas auditivas, não ter antecedentes de otites médias de repetição; ter respiração oral, não ter distúrbios de linguagem e de fala e saber ler.

Resultados: Quanto ao resultado da avaliação simplificada do processamento auditivo (ASPA) observamos que não houve diferença estatisticamente significante entre os grupos estudados, mas o desempenho do grupo I foi melhor, pois no grupo II houve cinco crianças $(66,66 \%)$ com alteração no teste de memória sequiencial verbal. A análise dos limiares dos reflexos acústicos mostrou limiares aumentados no GII em comparação ao GI. No teste SSI, na relação MCI (S/R 0, -10, -15), na comparação entre as orelhas direita e esquerda, das crianças dos GI e GII, houve diferença estatisticamente significante. Comparando as orelhas direita e esquerda, entre as crianças do GI e do GII, nas relações MCI S/R 0, -10, -15, somente na relação S/R -15 do GII houve diferença estatisticamente significante. Podemos concluir que as crianças do GII no teste SSI, na relação MCI, tiveram o desempenho pior que as do GI, pois as crianças que falharam no teste apresentaram alterações nas habilidades de figura-fundo. Assim como as crianças que falharam na ASPA demonstraram alterações no teste de memória sequiencial verbal, demonstrando alterações nas habilidades ordenação temporal.

Conclusão: Esses achados sugerem que crianças respiradoras orais apresentam problemas de atenção e concentração desencadeando alterações em habilidades auditivas importantes para o desempenho escolar. 


\section{ESTUDO LONGITUDINAL DAS FUNÇÕES NEUROVESTIBULAR E AUDITIVA EM CRIANÇAS COM INDICADORES DE RISCO PARA DEFICIÊNCIA AUDITIVA}

\section{Alessandra Kerli da Silva Manfredi}

Orientadora: Profa. Dra. Maria Cristina Lancia Cury Féres

Tese de Doutorado apresentada em 12/02/2008

A privação sensorial auditiva nos primeiros anos de vida de uma criança compromete não só a sua comunicação, mas seu potencial de linguagem receptiva e expressiva, seu desempenho acadêmico, emocional e social. As alterações do sistema vestibular podem acarretar déficits consideráveis no desenvolvimento global da criança principalmente sob o ponto de vista motor, interferindo assim negativamente sobre a qualidade de vida. Vários procedimentos para identificação e avaliação da audição do recém-nascido têm sido aplicados, no entanto não se observa a mesma preocupação com o sistema vestibular. Por constituírem dois sistemas com receptores periféricos dentro do mesmo órgão, na orelha interna, fatores de risco para deficiência auditiva poderiam também levar à disfunção vestibular. Este trabalho teve como objetivos estudar alguns reflexos posturais de recém-nascidos com indicadores de risco para deficiência auditiva, comparando-os com aqueles sem risco, avaliar a audição dos recém-nascidos e aos seis meses de vida e avaliar a evolução postural dos lactentes. Tratouse de um estudo descritivo, observacional, prospectivo, longitudinal. Inicialmente 102 recém-nascidos foram divididos em grupo controle sem risco para deficiência auditiva e grupo de estudo com pelo menos um risco. Foram avalia- dos auditivamente com o uso de emissões otoacústicas por transiente e com avaliação comportamental com a pesquisa do reflexo cócleo-palpebral. Para investigação do sistema neurovestibular foram pesquisados os reflexos de Moro, Tônico Cervical Assimétrico, Tônico Cervical Simétrico, Aceleração Vertical e Olhos de Boneca e a presença do nistagmo espontâneo . Aos seis meses 74 lactentes foram avaliados auditivamente através da avaliação comportamental instrumental, percepção de fala, lúdica com reforço visual investigando-se as condições da orelha média através da timpanometria. Em relação ao sistema neurovestibular, observou-se a condição motora, postural e presença dos nistagmos espontâneos e semi-espontâneos. Observou-se presença de emissões otoacústicas e do reflexo cócleo-palpebral em todos os recém-nascidos o que sugeriu integridade da função coclear. Através das avaliações comportamentais realizadas aos seis meses observouse um predomínio de respostas dentro do esperado sobre as alterações, onde apenas três lactentes apresentaram timpanometria sugestiva de alteração condutiva. Na investigação do sistema neurovestibular observou-se que as respostas motoras tanto reflexas quanto voluntárias no recém-nascido e aos seis meses estavam dentro do esperado para tal idade. Não houve diferença estatisticamente significante entre os grupos controle e de estudo, em nenhum teste aplicado tanto nos recém-nascidos quanto nos lactentes aos seis meses.

\section{INFLUÊNCIA DA IDADE E DA CIRURGIA DE ELEVAÇÃO TRANSPALPEBRAL NA ALTURA, CON- TORNO E MOTILIDADE DO SUPERCÍLIO}

\section{Fernando Procianoy}

Orientador: Prof. Dr. Antonio Augusto Velasco e Cruz

Tese de Doutorado apresentada em 27/02/2008

Os supercílios têm grande importância estética e na expressão facial. A motilidade e modificações do contorno do supercílio em indivíduos normais ainda não foram estudadas até o momento. A ptose dos supercílios, principalmente da região da cauda, é parte do envelhecimento facial. São conhecidas diversas técnicas cirúrgicas para elevação do supercílio, porém não existem avaliações objetivas de seus resultados. $\mathrm{O}$ estudo foi realizado com o objetivo de descrever e quantificar através da análise de medidas computadorizadas de fotos digitais o contorno, altura e deformação do supercílio à contração do músculo frontal em três diferentes grupos etários, e comparar o efeito de duas variações da cirurgia de elevação transpalpebral do supercílio na sua altura e motilidade em indivíduos com ptose de supercílio não paralítica. Foram fotografados 90 voluntários normais de 3 grupos etários ( $\mathrm{G} 1=5-10$ anos; $\mathrm{G} 2=20-30$ anos; $\mathrm{G} 3=60-85$ anos) com a face em repouso e após contração máxima forçada do músculo frontal. A excursão do supercílio foi medida e o contorno comparado através de representação gráfica de polinômios. Foram encontradas diferenças estatisticamente significativas entre os valores médios de excursão nos três grupos estudados entre as posições e na interação grupo versus posição. Em relação à comparação entre os grupos, esses foram diferentes em todas as posições. G1 apresentou os menores valores médios de excursão. Nos pacientes submetidos à cirurgia de elevação do supercílio por via transpalpebral, no grupo A (fixação em 2 pontos) houve elevação média estatisticamente significativa do $\mathrm{m}$ e $1,4 \pm 0,5 \mathrm{~mm}$ respectivamente). No grupo B (fixação em 3 pontos), houve elevação média estatisticamente significativa do supercílio nas posições dsupercílio nas posições do canto lateral e $35 \mathrm{~mm}$ lateral ao 
canto medial $(1,9 \pm 0,4 \mathrm{mo}$ canto lateral e $35 \mathrm{~mm}$ lateral ao canto medial $(2,1 \pm 0,2 \mathrm{~mm}$ e $2,4 \pm 0,3 \mathrm{~mm}$ respectivamente). Na análise utilizando ANOVA, houve interação significativa grupo versus posição apenas na posição mais temporal. Nos dois grupos houve redução da motilidade do supercílio 1 mês após a cirurgia de elevação transpalpebral. Os resultados observados demonstram que na população normal, há um aumento da motilidade do supercílio com o avanço da idade. As técnicas de elevação do supercílio com fixa- ção interna ao periósteo por via transpalpebral apresentam bons resultados a curto prazo, permitindo uma elevação das porções mais laterais do supercílio. A utilização de um terceiro ponto de fixação da cauda do supercílio à fáscia temporal permite uma elevação maior da sua porção mais lateral. A redução da motilidade após a fixação interna do supercílio apresentou uma forte correspondência à localização dos pontos de fixação, o que sugere um efeito restritivo dos mesmos.

\section{ORTOPEDIA, TRAUMATOLOGIA E REABILITAÇÃO}

\section{EFEITOS MORFOLÓGICOS DA ATIVIDADE AQUÁTICA NOS MÚSCULOS SÓLEO E TIBIAL ANTERIOR DE RATAS APÓS IMOBILIZAÇÃO GESSADA DOS MEMBROS POSTERIORES}

\section{Camila de Carvalho Freitas do Nascimento \\ Orientadora: Profa. Dra. Ana Cláudia Mattiello-Sverzut \\ Dissertação de Mestrado apresentada em 15/01/2008}

O tecido muscular esquelético possui a importante característica de se adaptar às alterações nas demandas funcionais. Este trabalho teve como objetivo verificar o quanto o treinamento aquático prévio pode interferir nos processos de imobilização e reabilitação. Para tanto, foram utilizadas 24 ratas Wistar, divididas em quatro grupos experimentais: controle (GC) - seis semanas em condições basais; treinado (GT) - submetido à natação por seis semanas; treinado-imobilizado (GTI) - treinado com natação e imobilizado uma semana; treinado-imobilizado-reabilitado (GTIR); submetido a treinamento, imobilizado uma semana e remobilizado com natação por duas semanas. Após essas etapas os animais foram submetidos à eutanásia e os músculos sóleo e tibial anterior foram retirados e congelados em nitrogênio líquido para processamento com diferentes métodos histoquímicos. A análise estatística foi realizada entre grupos utilizando Modelo Linear de Efeitos Mistos $(\mathrm{p}<0,05)$. O músculo sóleo foi o que mais sofreu aos estímulos externos submetidos, sendo destacado o GTI por apresentar intensa incidência de necrose e média incidência de fibras lobuladas, núcleos centralizados e aumento de tecido conjuntivo. As fibras tipo 1 e $2^{\mathrm{A}}$ desse mesmo grupo e músculo apresentaram-se com redução no diâmetro menor em relação ao GT. No músculo tibiais anteriores não foram encontradas alterações significativas no diâmetro menor das fibras, entretanto, observou-se que a imobilização póstreinamento determinou aumento no número das FT2B e redução no número das FT2A quando comparada ao GT, o contrário aconteceu após a remobilização, onde houve redução no número de FT2B e aumento no número de FT2A em relação ao GTIR. Podemos sugerir que o treinamento prévio não minimizou os efeitos deletérios da imobilização nos músculos estudados, o que pode ter acontecido pela intensidade e tempo de protocolo.

\section{INFLUÊNCIA DO MACHEAMENTO NA INTERFACE DO PARAFUSO E DO TECIDO ÓSSEO NA FASE IMEDIATA PÓS-IMPLANTE}

\section{Fabiano Pinheiro de Lemos Masson \\ Antônio Carlos Shimano \\ Dissertação de Mestrado apresentada em 22/01/2008}

A colocação dos parafusos no interior da vértebra é um passo técnico freqüente e de grande importância na cirurgia de coluna vertebral, pois a ancoragem dos parafusos é a base para o desempenho da função biomecânica do sistema de fixação. A técnica de inserção, o preparo do orifício piloto, o desenho do tipo de parafuso, a integridade e a densidade do mineral do tecido ósseo influenciam no grau de fixação do parafuso no tecido ósseo, e desse modo na estabilidade do sistema de fixação e no resultado final do tratamento. A finalidade deste estudo foi analisar as alterações da interface entre o osso e o implante com aplicação da técnica de macheamento na região trabecular de vértebras cervicais, analisadas através de histomorfometria. Foram analisadas 4 itens; a) número de trabéculas fratura- 
das entre os filetes de rosca do parafuso, b) maior distância da fratura trabecular transversal provocada pela inserção do parafuso, c) maior extensão da fratura trabecular longitudinal provocada pela inserção do parafuso, d) linha de contato na interface osso-parafuso. Foram utilizados 5 carneiros adultos da raça Santa Inês deslanado com peso médio de $(46,00 \pm 17,74) \mathrm{kgf}, 10$ parafusos corticais de aço inoxidável de diâmetro externo de $3,5 \mathrm{~mm}$, diâmetro interno de $2,7 \mathrm{~mm}$ e comprimento de $18,0 \mathrm{~mm}$, broca de $2,5 \mathrm{~mm}$ e macho de $2,5 \mathrm{~mm}$ de diâmetro. Foram realizados quatro orifícios pilotos utilizando broca, dois na região proximal e dois na região distal do corpo anterior da vértebra. $\mathrm{O}$ orifício proximal direito foi realizado o macheamento anteriormente a inserção do parafuso cortical (grupo A), o orifício proximal esquerdo o parafuso foi inserido sem realizar a técnica de macheamento (grupo B), os dois orifícios distais foram os controles (grupo C). Logo que cessado o procedimento o animal foi morto com uma dose excessiva de Thiopental e removida e terceira vértebra cervical. As vértebras passaram por 5 processos antes de realizar as confecção das lâminas. Seguindo esta ordem: 1) fixação com solução de formol tamponada a 4\%, 2) desidratação com uma seqüên- cia de diferentes concentrações de álcoois, 3) impregnação da sustância com resina, 4) corte dos blocos, 5) lixamento e polimento, 6) coloração com Stevene/'s Blue e Alizarin Red. As lâminas foram digitalizadas e depois analisadas. Os valores do número de fraturas (a), maior distância (b) e maior extensão (c) da interface parafuso-osso, estão apresentados respectivamente para os três grupos experimentais: a) $\mathrm{A}(2,33 \pm 0,92), \mathrm{B}(2,03 \pm 1,01)$ e $\mathrm{C}(0,66 \pm 0,69), \mathrm{b}) \mathrm{A}(0,68 \pm 0,31$ )mm, B( $0,63 \pm 0,35) \mathrm{mm}$ e C $(0,17$ '+OU-' 0,23$) \mathrm{mm}$, e c) $\mathrm{A}(0,50$ $\pm 0,22) \mathrm{mm}, \mathrm{B}(0,44 \pm 0,31) \mathrm{mm}$ e $\mathrm{C}(0,16 \pm 0,18) \mathrm{mm}$. O grupo $\mathrm{A}$ e $\mathrm{B}$ teve uma média superior do que o grupo $\mathrm{C}$ com um nível de significância de $\mathrm{p}<0,001$. O grupo A comparado ao B apresentou valores superiores, mas sem diferença estatística significativa. As linhas de contato dos grupos A e B, são respectivamente: $(0,71 \pm 0,62) \mathrm{mm}$ e $(0,38 \pm 0,44) \mathrm{mm}$, na comparação entre os dois grupos foi verificado diferença estatística significativa ( $\mathrm{p}=0,0164)$. Em valor absoluto, a inserção do parafuso após o macheamento, causou maior número de fraturas e mais distante e extensa na interface parafuso-osso, quando comparado com a inserção do parafuso sem macheamento e proporcionou maior medida da linha contato.

\section{ANALISE FOTOELÁTICA DE UM MODELO DE VÉRTEBRA SOB A INFLUÊNCIA DE PARAFUSO PEDICULAR}

\section{Dayana Pousa Paiva de Siqueira \\ Orientadora: Profa. Dra. Ana Claudia Mattiello-Sverzut Dissertação de Mestrado apresentada em 01/02/2008}

O sistema de fixação vertebral utilizando o parafuso pedicular é um dos métodos mais eficientes no tratamento de patologias da coluna vertebral. Quando o parafuso estiver submetido à força arrancamento, ele gera tensões ao redor, principalmente próximo do canal medular, situação que pode ser analisada pela técnica da fotoelasticidade. $\mathrm{O}$ objetivo foi analisar as tensões internas geradas de modelos fotoelásticos de vértebras, utilizando diferentes medidas de parafusos do sistema de fixação vertebral, submetidos à força de arrancamento. Foi utilizado um modelo de vértebra lombar em material fotoelástico utilizando três medidas de diâmetros externos de parafusos pediculares $(5,6 \mathrm{e}$ $7 \mathrm{~mm}$ ) do tipo USS1. As tensões internas ao redor do parafuso foram avaliadas em 18 pontos pré-determinados utilizando um polariscópio de transmissão plana. As regiões de maiores concentrações de tensões foram observadas entre o canal medular e as curvas do processo transverso. Nas comparações das médias das tensões cisalhantes entre os parafusos 5 e $7 \mathrm{~mm}$, e 6 e $7 \mathrm{~mm}$ foram observadas diferenças estatísticas significativas, o que não ocorreu com os parafusos de 5 e $6 \mathrm{~mm}$ onde não foram observadas diferença estatisticamente significativa. Foi observado que as tensões internas são mais elevadas em área irregulares próximas do canal medular, o que sugere ser uma região crítica, em termos de esforços mecânicos.

\section{DISTRIBUIÇÃO DE TENSÕES DE PARAFUSOS DO SISTEMA DE FIXAÇÃO VERTEBRAL SUBME- TIDOS A ARRANCAMENTO UTILIZANDO FOTOELASTICIDADE DE TRANSMISSÃO PLANA}

Sarah Fakher Fakhouri

Orientador: Prof. Dr. Antonio Carlos Shimano

Dissertação de Mestrado apresentada em 12/02/2008
O tratamento de deformidade espinhal, doença degenerativa, trauma, e tumores da coluna vertebral exigem frequientemente a realização da fixação interna. O surgimento 
dos parafusos pediculares possibilitou a realização da instrumentação segmentar da coluna mais estável, tornando-se atualmente procedimento padrão para realização das cirurgias de correção, estabilização de deformidade e instabilidade da coluna em patologias torácicas, lombares e sacrais. O segmento vertebral mais favorável para a implantação do parafuso é a região lombar, devido ao maior diâmetro dos pedículos. A fotoelasticidade tem sido utilizada em estudos científicos a fim de determinar a distribuição de tensões/deformações em sistemas estruturais, pois permite uma análise qualitativa e quantitativa do estado de tensão, através da observação de efeitos óticos. Neste trabalho foi utilizada esta técnica para determinar e analisar as tensões internas de modelos fotoelásticos sob influência de parafusos pediculares tipo USS1, quando submetidos a esforços de arrancamento. Para realização das análises fotoelásticas foram confeccionados 12 modelos divididos em três grupos, contendo em cada 4 modelos fotoelásticos $\mathrm{O}$ primeiro grupo, G1, era composto pelo parafuso com diâ- metro externo de $5 \mathrm{~mm}$, o segundo, G2, era formado pelo parafuso com diâmetro externo de $6 \mathrm{~mm}$ e o terceiro, G3, era composto parafuso com diâmetro externo de $7 \mathrm{~mm}$. A simulação foi feita utilizando cargas de 0,75 e 1,5 Kgf. As ordens de franjas foram avaliadas em torno dos parafusos, utilizando o método de compensação de Tardy. Em todos os modelos analisados foram determinadas as tensões cisalhantes. Os resultados mostraram que para a carga de $0,75 \mathrm{Kgf}$, a tensão cisalhante máxima no parafuso de $5 \mathrm{~mm}$ foi maior que no de $6 \mathrm{~mm}$, que foi maior que no de $7 \mathrm{~mm}$. Com a carga de 1,5 Kgf houve igualdade nos três diâmetros externos de parafusos, e comparando estas duas cargas prevaleceu o último resultado. De acordo com as análises realizadas nos doze modelos, observou-se que o local de maior tensão é no pico das cristas, principalmente próxima a ponta dos parafusos. Sendo assim, esta técnica é bastante eficiente, pois, através da análise quantitativa e qualitativa foi possível comparar os parafusos de fixação vertebral, verificando qual é o mais suscetível ao arrancamento.

\section{APLICAÇÃO DO ULTRA-SOM DE BAIXA INTENSIDADE EM DEFEITOS ÓSSEOS METAFISÁRIOS DISTAIS DO RÁDIO DO CÃO (Canis lupus familiaris, Linnaeus, 1758)}

\section{Francisco Claudio Dantas Mota}

Orientador: Prof. Dr. José Batista Volpon

Tese de Doutorado apresentada em 28/02/2008

As anomalias de consolidação óssea são, ainda, situações de difícil manejo na Ortopedia, principalmente quando o paciente apresenta fatores de risco para cirurgia, que é o tratamento eletivo para a condição. Assim, buscam-se métodos não invasivos que possam tratar ou prevenir anomalias de consolidação. Está bem estabelecido que o ultrasom de baixa intensidade tem efeito estimulante sobre a neoformação óssea. O objetivo desta pesquisa foi avaliar os resultados da aplicação do ultra-som de baixa intensidade no processo de reparação de falha óssea criada na extremidade distal do rádio de cães adultos. Para tanto foram usados 16 cães adultos, machos, com peso entre oito e 12 $\mathrm{kg}$, em que se criou cirurgicamente um defeito de 3,0 mm de largura na metáfise distal do rádio, com uma osteotomia transversal de ressecção. Os animais foram divididos em dois grupos: grupo I (controle) e o grupo II submetido à aplicação do ultra-som de baixa intensidade, que ocorreu sobre a região da osteotomia, durante 20 minutos por dia, cinco dias por semana, durante três meses. Os animais de ambos os grupos foram acompanhados durante 100 dias após a cirurgia. O processo de reparação foi avaliado por radiografias seqüenciais, histomorfometria, histologia por fluorescência do osso e vascularização óssea. Todos os animais de ambos os grupos, evoluíram para um estágio de não-consolidação do tipo hipertrófica. A análise histológica mostrou a formação de tecido fibrocartilaginoso, preenchendo a região da osteotomia, para ambos os grupos. No entanto, os animais tratados apresentaram áreas de ossificação endocondral no meio da região de fibrocartilagem. Os resultados morfométricos mostraram diferença estatística apenas na área de tecido conjuntivo denso, que foi maior no grupo controle. A não-consolidação óssea observada neste modelo, deve-se, possivelmente, a uma série de fatores relacionados com o modelo de osteotomia aqui empregado como: presença da falha óssea, manutenção desta falha pela ulna, presença da falha próxima à articulação que leva à maior mobilidade dos fragmentos, ressecção do periósteo e a oclusão do canal medular pela cera óssea. Estes fatores, em conjunto, criaram uma condição patológica que, provavelmente, ultrapassou os limites de reparação promovidos pelo ultra-som de baixa intensidade. Já, a presença de áreas de ossificação endocondral, e a baixa quantidade de tecido conjuntivo denso, observadas no grupo tratado, podem ter ocorrido pelo estímulo da condrogênese precoce e da ossificação.

A aplicação do ultra-som de baixa intensidade não foi capaz de alterar significativamente o processo de nãoconsolidação que se estabelece após a criação de uma falha óssea na metáfise distal de rádio de cães adultos. 


\section{PATOLOGIA EXPERIMENTAL}

\section{PERFIL ANTROPOLÓGICO DAS OSSADAS ANALISADAS NO CENTRO DE MEDICINA LEGAL (CEMEL) DA FACULDADE DE MEDICINA DE RIBEIRÃO PRETO - USP}

\author{
Andjara Thiane Cury Soares \\ Orientador: Prof. Dr. Marco Aurelio Guimarães \\ Dissertação de Mestrado apresentada em 11/02/2008
}

AAntropologia Forense é uma área do conhecimento que aplica os métodos da antropologia física e arqueologia para coleta e análise de evidências legais, buscando estabelecer a identidade de um ser. O Centro de Medicina Legal (CEMEL) da Faculdade de Medicina de Ribeirão Preto da Universidade de São Paulo (FMRP-USP) possui um Laboratório de Antropologia Forense, criado em 2005 durante o desenvolvimento de um projeto em parceria com a University of Sheffield (UK) e financiado pelo British Foreign and Commonwealth Office Global Opportunities Fund. Durante esse projeto, um protocolo para análise de ossadas foi implementado dentro de uma estrutura científica atualizada para aplicação em contextos de importância social. Após dois anos de funcionamento, constatou-se que muitas das ossadas encaminhadas ao CEMEL estavam incompletas, tornando a realização de um perfil biológico difícil e postergando a sua identificação devido à ausência de informações e literatura nacional recente sobre Antropologia Forense. Assim, 42 ossadas humanas examinadas no CEMEL desde sua inauguração em 1999 foram analisadas e revisadas. Os resultados mostraram que a maioria dos casos era de indivíduos do sexo masculino, de ancestralidade caucasiana, com idade entre 32,71 e 46,29 anos, estatura entre 1,64 e 1,73m, destros, sem achados patológicos, com elementos odontológicos informativos, mas sem roupas ou outros pertences. Observou-se que $61,90 \%$ das ossadas possuíam menos de $50 \%$ dos ossos, com média de $79,64 \pm 52,40$ ossos por caso. Os ossos mais encaminhados foram occipital, parietal esquerdo, temporal esquerdo, parietal direito, temporal direito, fêmur direito e vértebras torácicas de um a 12 . Os ossos menos encaminhados foram hióide, piramidal esquerdo, falange distal superior um direita, falanges distais superiores dois a cinco direitas e falanges médias superiores dois a cinco esquerdas. Os dentes mais encaminhados foram o $2^{\circ}$ molar superior direito e o $1^{\circ}$ molar superior direito, enquanto que os dentes menos encaminhados foram o incisivo central superior direito, os incisivos centrais inferiores direito e esquerdo. Roupas e outros pertences estavam presentes em 20 casos, totalizando 66 itens. Trinta e um casos têm potencial para identificação somente através de técnicas de Antropologia Forense. Para os demais 11 casos provavelmente será necessário utilizar DNA para identificação. Diante dos resultados observados, discute-se a necessidade de melhorias na capacitação técnica e infra-estrutura, assim como a forma de coleta e o transporte, de forma a aumentar o número de elementos ósseos coletados e, conseqüentemente, de informações útéis para identificação. Dois crânios apresentaram evidência de craniotomia realizada durante necropsia e um apresentou resíduos de vela, o que sugere que podem ter sido retirados indevidamente do local de sepultamento, ou até mesmo vendidos, além da sua utilização em rituais religiosos. Conclui-se que campanhas de conscientização e melhorias na fiscalização dos cemitérios podem reduzir os casos de roubos e comércio de elementos ósseos.

\section{ISOPROTERENOL INDUZ A PERDA PRIMÁRIA DE DISTROFINA: CORRELAÇÃO COM A INJÚ- RIA MIOCÁRDICA}

\section{Érica Carolina Campos}

Orientador: Prof. Dr. Marcos Antônio Rossi

Dissertação de Mestrado apresentada em 29/02/2008

Este estudo teve como objetivo avaliar as alterações do complexo de glicoproteínas associadas à distrofina que conferem estabilidade estrutural aos cardiomiócitos na isquemia miocárdica induzida pelo isoproterenol.

Materiais e Métodos: Ratos Wistar machos foram divididos em dois grupos: grupo controle (SAL), injeção subcutânea de salina, e grupo isoproterenol (ISO), injeção subcutânea de isoproterenol $(85 \mathrm{mg} / \mathrm{kg})$ diluído em água destilada, em dois dias consecutivos separados por intervalo de $24 \mathrm{~h}$. Os ratos foram mortos 24 horas após a segunda injeção de salina ou isoproterenol. Os corações foram rapidamente excisados, lavados em salina gelada, pesados e colocados em formol PBS por $24 \mathrm{~h} \mathrm{a} 4^{\circ} \mathrm{C}$ e incluídos em parafina ou Historesina. Para análise morfométrica, os corações 
foram cortados transversalmente na porção medioventricular, equidistante entre o ápice e a base, e incluídos em parafina. Áreas dos ventrículos direito e esquerdo, espessura de parede livre dos ventrículos e septo interventricular foram medidas. Os corações cortados frontalmente nas metades anterior e posterior e incluídos em Historesina foram utilizados para avaliação das áreas de miocitólise. Porções hemiventriculares foram congeladas para as reações de imunofluorescência com os seguintes marcadores: distrofina, $\beta$-1 integrina, $\alpha$-actina sarcomérica, $\gamma$-sarcoglicana, $\beta$-distroglicana, merosina laminina, albumina, CD68, CD45, CD4 e eNOS. A apoptose foi avaliada através do método de TUNEL. A função cardíaca, as dimensões das cavidades ventriculares e a mobilidade de parede foram analisadas através da ecocardiografia. A análise estatística foi realizada através do teste t de Student, com nível de significância de 5\%.

Resultados e Conclusão: Houve diferença significativa no peso do coração, na taxa de crescimento corporal, na área do ventrículo esquerdo e na espessura de parede do ventrículo direito entre os grupos. Não houve diferença estatística significativa na espessura da parede do ventrículo esquerdo e septo, mas observou-se tendência à diminuição. As áreas de miocitólise representaram 26,89\%, $36,12 \%, 28,15 \%$ no ventrículo direito, septo e ventrículo esquerdo, respectivamente. A imunofluorescência mostrou que a distrofina foi a estrutura mais sensível ao dano pro- vocado pelo isoproterenol, seguida pela perda completa da actina. A redução na expressão de $\gamma$-sarcoglicana, $\beta$ distroglicana, $\beta$-1 integrina e laminina, foram considerados como epifenômenos. A expressão de eNOS estava praticamente ausente nas áreas de miocitólise. A expressão aumentada de eNOS nos pequenos vasos ao redor das áreas de miocitólise sugere uma resposta compensatória à isquemia provocada pelo isoproterenol na tentativa de melhora do fluxo sangüíneo para as áreas de lesão. Foi observada alteração na permeabilidade sarcolemal nos cardiomiócitos dos animais tratados com isoproterenol com acúmulo de albumina no espaço intracelular. Observou-se que os cardiomiócitos e os macrófagos estavam constante e claramente marcados para apoptose nas áreas de miocitólise. Na ecocardiografia, os diâmetros sistólico e diastólico do ventrículo esquerdo foram significativamente maiores no grupo ISO em comparação com os controles. A fração de ejeção não foi diferente entre os grupos. O escore de mobilidade de parede mostrou hipocinesia ou acinesia nos segmentos apicais nos corações do grupo ISO. Essas mudanças, relacionadas à isquemia, podem explicar as graves alterações na integridade estrutural do sarcolema dos cardiomiócitos e a lesão induzida pelo isoproterenol. Mecanismos compensatórios no curto período de nosso experimento poderiam manter a função cardíaca normal apesar das graves alterações morfológicas encontradas.

\section{MENSURAÇÃO DE TECIDOS MOLES DA FACE DE BRASILEIROS VIVOS EM IMAGENS DE RES- SONÂNCIA MAGNÉTICA (RM) PARA FINS MÉDICO-LEGAIS}

\section{Welson Donizeti Florentino dos Santos}

Orientador: Prof. Dr .Marco Aurelio Guimarães

Tese de Doutorado apresentada em 31/03/2008

A reconstrução facial pode ser uma ferramenta útil dentro do processo de identificação médico-legal. O método tem apresentado evolução contínua ao longo dos anos, tornando-se mais acurado. A literatura atual mostra que este avanço deve-se em parte à precisão das medidas de tecidos moles que são empregadas para se reconstituir o rosto a partir de um crânio. Contudo, é também sabido que diversas características de uma dada população como sexo, idade, etnia, entre outras podem determinar variações importantes na espessura dos tecidos moles crânio-faciais. No Brasil, não foram localizados registros de medidas desses tecidos, sendo que para a execução de reconstruções faciais forenses, tabelas estrangeiras são normalmente utilizadas, o que pode gerar distorções de resultados. A proposta deste estudo foi definir a correta localização de 22 pontos craniométricos - relatados previamente na literatura a partir de estruturas anatômicas para utilização em re- construções faciais forenses - e, a partir deles, obter medidas dos tecidos moles crânio-faciais, as mais precisas e confiáveis possíveis numa população de brasileiros vivos, utilizando-se imagens digitais multiplanares de exames de ressonância magnética nuclear (RMN). Para isso, foram necessárias mudanças na forma de localizar as referências anatômicas ósseas e seus correspondentes em tecidos moles, especialmente em três pontos, onde o conhecimento detalhado de anatomia dental é requerido. O estabelecimento dessas definições permitiu a padronização e a validação de uma metodologia de medida dos tecidos moles crânio-faciais em imagens multiplanares de RMN, o que embasou a coleta dessas medidas teciduais para a elaboração de uma tabela antropomórfica contendo valores representativos de uma amostra populacional de brasileiros vivos, de forma a minimizar a lacuna existente na aplicação da Medicina Legal brasileira de uma técnica reconhecida internacionalmente. Os resultados obtidos neste trabalho são propostos para utilização em reconstruções faciais forenses a serem executadas para a população brasileira, de forma a permitir, inclusive, estudos comparativos com outras populações estrangeiras. 


\section{SAÚDE DA CRIANÇA E DO ADOLESCENTE}

\section{PREVALÊNCIA E GRAVIDADE DOS SINTOMAS DE ASMA, RINITE E ECZEMA, EM ESCOLARES DE 6 A 7 ANOS, NA CIDADE DE SÃO JOSÉ DO RIO PRETO, SP, AVALIADOS PELO ISAAC (INTERNATIONAL STUDY OF ASTHMA AND ALLERGIES IN CHILDHOOD)}

\author{
Ana Maria Cavalini Rossi Menin \\ Orientadora: Profa. Dra. Virgínia Paes Leme Ferriani \\ Dissertação de Mestrado apresentada em 21/02/2008
}

Foram estudadas a prevalência e a gravidade dos sintomas de asma, rinite e eczema atópico, em escolares de 6 e 7 anos, em São José do Rio Preto, SP, utilizando-se o questionário escrito e padronizado pelo ISAAC (International Study of Asthma and Allergies in Childhood). O questionário escrito, com oito (8) questões relacionadas à asma, seis (6) relacionadas à rinite e seis (6) ao eczema, foi aplicado à população randomizada de 5876 crianças de $6 \mathrm{e}$ 7 anos matriculadas em 48 escolas públicas e 10 escolas privadas; os pais das crianças é que responderam às questões. O Critério Combinado para eczema foi definido segundo critérios publicados (ASHER et aI., 1995; CAMELO-NUNES et aI., 2004). A taxa de respostas obtidas foi de $62 \%$. Houve um discreto predomínio do sexo feminino na população estudada. Neste grupo de crianças, 18,8\% responderam ter tido chiado no último ano e 5,9\% tinham asma; 29,8\% relataram ter tido sintomas de rinite no último ano e $30,9 \%$ referiram diagnóstico de rinite; sintomas de eczema no último ano foram relatados por 9,2\% e o diagnóstico de eczema esteve presente em $11,7 \%$ das crianças estudadas. A prevalência de "Critério Combinado" para eczema foi de $5,8 \%$. No presente estudo, a prevalência de sintomas de asma, de rinite e do eczema, concomitantemente, foi de $2,8 \%$ e o diagnóstico das três doenças, concomitantemente, foi de $1,2 \%$. No presente estudo, a comparação entre os sintomas e o diagnóstico da asma revela um subdiagnóstico da asma, o que está de acordo com estudos realizados em todo o mundo, sugerindo que a pergunta "já teve asma?", é específica, porém pouco sensível. Quanto à rinite e ao eczema, a comparação entre os sintomas e o diagnóstico das mesmas, mostrou prevalêncía maior de diagnóstico do que de sintomas, no último ano.

\section{AVALIAÇÃO NUTRICIONAL DE RETINOL, $\beta$-CAROTENO E $\alpha$-TOCOFEROL EM CRIANÇAS INFECTADAS E NÃO INFECTADAS POR HIV}

\section{Lidiane Bernardes Faria Vilela}

Orientadora: Profa. Dra. Jacqueline Pontes Monteiro Dissertação de Mestrado apresentada em 03/03/2008

O objetivo é descrever a freqüência de deficiência de retinol, $\beta$-caroteno e $\alpha$-tocoferol, em crianças infectadas (HIV+) e não infectadas (HIV-) por HIV-1, e comparar deficiências de micronutrientes com estado de infecção por HIV1. Os países participantes do protocolo do Instituto Nacional de Saúde e Desenvolvimento Humano da Criança foram a Argentina, o Brasil e o México. Sendo que 336 crianças com idade entre 1-3 anos participaram do estudo (124 HIV+ e 212 HIV-). Os níveis séricos das vitaminas foram determinados por cromatografia líquida de alta eficiência. As deficiências de retinol, $\beta$-caroteno e $\alpha$-tocoferol foram definidas quando os níveis séricos estavam abaixo de $0,7 \mu \mathrm{mol} / \mathrm{L}$, $0,35 \mu \mathrm{mol} / \mathrm{L}$ e $18 \mu \mathrm{mol} / \mathrm{L}$, respectivamente. Não foi observada diferença estatisticamente significante entre as medianas dos níveis séricos de vitaminas entre as crianças HIV+ e HIV-. Níveis séricos medianos de retinol e á-tocoferol estavam abaixo de limites normais [HIV+/HIV- 0,5/0,6 e HIV+/ HIV- 12,4/11,4 $\mu \mathrm{mol} / 1$ respectivamente], mas não no $\alpha$ caroteno $[1,8 / 1,1 \mu \mathrm{mol} / 1]$. Do total de crianças, $74 \%$ tiveram deficiência de retinol, $27 \%$, de $\beta$-caroteno, e $89 \%$, de $\alpha$ tocoferol. Nenhuma diferença estatística foi encontrada na proporção de deficiências de micronutrientes pelo estado de infecção por HIV-1 ou suplementação de vitaminas. A frequiência de deficiência de retinol, $\beta$-caroteno e á-tocoferol foi alta entre crianças inscritas neste estudo. Nenhuma diferença significante foi encontrada conforme infecção por HIV-1, de acordo com o relatado pelos cuidadores das crianças. Ainda é obscuro se a alta proporção dos baixos níveis séricos dessas vitaminas é atribuível às deficiências na população desses países ou ao ponto de corte que foi validado para os países desenvolvidos, o que pode não ser válido para outras áreas do mundo. Deficiências são comuns nestes grupos de crianças infectadas e crianças não infectadas, filhas de mães infectadas por HIV-1, e podem ser mais graves do que parecem clinicamente. 


\section{FATORES PERINATAIS E DA VIDA ADULTA JOVEM ASSOCIADOS À ADIPOSIDADE}

\section{Vanda Maria Ferreira Simões}

Orientador: Prof. Dr. Marco Antonio Barbieri

Tese de Doutorado apresentada em 03/03/2008

Introdução: Nos últimos dez anos estudos têm evidenciado a importância dos fatores biológicos, ambientais, psicossociais e comportamentais em determinados momentos da vida, na gênese de doenças crônicas a longo prazo e a associação entre alguns fatores de riscos precursores dessas doenças na criança, durante a adolescência e na fase adulta. $\mathrm{O}$ índice de massa corporal (IMC) e circunferência de cintura (CC) vêm sendo utilizados em estudos de base populacional como bons indicadores de adiposidade, tanto pela associação com os fatores de risco associados à obesidade, quanto pela alta correlação com métodos laboratoriais de avaliação de composição corporal.

Objetivos: Verificar associação entre índice de massa corporal ao nascer e adiposidade na vida adulta jovem, aos 23/25 anos de idade, ou seja, em uma população jovem de um país em desenvolvimento.

Metodologia: Estudo longitudinal baseado na coorte de nascimentos de 1978/79 de Ribeirão Preto. A variável dependente utilizada foi IMC e CC na vida adulta e a variável independente foi IMC ao nascer, ajustada sequencialmente para os vários fatores de confusão em quatro modelos: $1^{\circ}$. modelo -ajustado para prematuridade; $2^{\circ}$. modelo ajustado para as variáveis de nascimento: fumo, escolaridade, idade, situação conjugal maternos e paridade, além de prematuridade; $3^{\circ}$. modelo -ajustado para as variáveis da vida adulta: escolaridade, ocupação, situação conjugal, fumo, consumo de álcool e percentual de gordura na dieta, além de prematuridade; $4^{\circ}$. modelo -ajustado para todas as variáveis do nascimento e vida adulta. Foi utilizado o modelo estatístico de regressão linear múltipla.

Resultados: O IMC ao nascer associou-se com o IMC na vida adulta jovem apenas para o sexo feminino. Houve aumento de $0,25 \mathrm{~kg} / \mathrm{m}^{2}$ na idade adulta, para cada 1 $\mathrm{kg} / \mathrm{m} 2$ ao nascer (IC 95\% 0,008-0,490), quando ajustado para variáveis do nascimento, e aumento de $0,28 \mathrm{~kg} / \mathrm{m}^{2}$ na idade adulta para cada $1 \mathrm{~kg} / \mathrm{m}^{2}$ ao nascer (IC 95\% 0,034-0,495), quando ajustado para todas as variáveis (do nascimento e da vida adulta). Foram encontradas associações significantes do IMC ao nascer com o IMC na vida adulta jovem, no sexo feminino, com outras variáveis como escolaridade da mãe, ocupação manual semiqualificada, situação conjugal casada e com número de gestações. No sexo masculino encontrou-se associação com situação conjugal casado, consumo de álcool e consumo alto de gordura em homens. Não houve associação do IMC ao nascer com CC na vida adulta jovem em nenhum dos modelos seqüenciais de ajuste, mas houve associação no sexo feminino com ocupação semiqualificada do chefe da família atual, situação conjugal casada e ex-fumantes. No sexo masculino, associou com escolaridade baixa das mães, situação conjugal casado, uso de álcool e alto percentual de gordura na dieta.

Conclusão: Os resultados mostraram que à medida que aumentou a adiposidade ao nascer, medido pelo IMC, aumentou também a adiposidade na vida adulta jovem em mulheres. Em relação à CC, não houve associação do IMC ao nascer com CC na vida adulta, mas houve associação com as variáveis sociais e comportamentais.

\section{SAÚDE NA COMUNIDADE}

\section{ANÁLISE EPIDEMIOLÓGICA DA TUBERCULOSE E CO-INFECÇÃO HIV/TB, EM RIBEIRÃO PRE- TO- SP, DE 1998-2006}

\section{Maria Elvira Santos de Lucca \\ Orientador: Prof. Dr. Antonio Ruffino Netto \\ Dissertação de Mestrado apresentada em 11/02/2008}

A pesquisa teve como objetivo analisar o Programa de Controle da Tuberculose (PCT) no município de Ribeirão Preto -São Paulo, no período de 1998 a 2006. Utilizou- se para este propósito indicadores epidemiológicos e de desempenho construídos a partir de dados das fichas de notificação de tuberculose (TB) armazenadas no sistema de informação o EPI-Tb, da Secretaria municipal de saúde deste município e os dados populacionais de estimativas do DATASUS, do período de estudo. Selecionaram-se para o estudo casos novos de TB notificados e residentes no 
município, por ano de diagnóstico, excluindo-se casos atendidos em outros municípios e presidiários. No período compreendido entre 1998 a 2006 foram notificados no EPI-Tb da SMS/Ribeirão Preto 1623 casos novos de tuberculose, sendo que houve queda no número absoluto de casos e no coeficiente de incidência de 47,8\% (50,01-26,08) dos casos no período ou 5,3\% ao ano. O risco de ser um caso novo de TB foi 2,4 vezes maior para homens que para as mulheres. Apesar do número de casos notificados serem maiores na faixa etária de 15 a 49 anos, o risco de adoecer por TB foi maior na faixa etária acima de 50 anos, a partir de 2001 . O percentual de co-infecção HIV/TB ficou em 27,1\% (prevalência mínima), mas a prevalência máxima foi de 32,7\%. A forma clínica mais freqüente para os casos novos foi a pulmonar com $85 \%$, enquanto para os casos co-infectados esta forma esteve presente em 58,3\% deles e a extra pulmonar em $27,8 \%$. O local de descoberta dos casos de TB foi $51 \%$ em ambulatórios (públicos e privados), 39\% em hospitais (universitários, público e privados) e 10\% outras formas. Uma das fragilidades observadas foi a baixa detecção de casos de TB no município que nos últimos anos ficou próxima de $45 \%$ e que as unidades básicas de saúde e PCTs realizam apenas um quinto das baciloscopias de escarro para diagnóstico que deveriam realizar (segundo estimativas do MS). No entanto uma das fortalezas foi a implantação do tratamento supervisionado no município, que iniciou efetivamente em 1998, e foi aumentando gradativamente, chegando em 2006 a supervisionar $76 \%$ dos casos. Houve melhora nas taxas de cura, ficando próximo à $72 \% \mathrm{e}$ $50,5 \%$, para os casos novos sem co-infecção e com coinfecção HIV/TB, respectivamente. A taxa de mortalidade por TB no município apresentou ligeira tendência de queda no período. Apesar da baixa letalidade no período, 50,8\% dos óbitos por TB só foram diagnosticados e notificados após o óbito; indicando dificuldade de acesso ao diagnóstico e tratamento da TB nestes casos. Conclui-se que para melhorar a detecção de casos de TB no município serão necessárias mudanças na forma de acolher os indivíduos suspeitos de TB na atenção básica de saúde, facilitando seu acesso a essas unidades, além de investigar mais sintomáticos respiratórios na comunidade. Algumas ações de controle da doença poderiam ser descentralizas, como o tratamento supervisionado e controle de comunicantes. Para os pacientes co-infectados HIV/TB apenas o tratamento supervisionado não está sendo suficiente para alcançarem sucesso no tratamento. 